\title{
FEDERALISM AND THE DOUBLE STANDARD OF JUDICIAL REVIEW
}

\author{
LYNN A. BAKER $\dagger$
}

ERNEST A. YOUNG $\dagger \dagger$

\section{INTRODUCTION}

From 1937 to 1995 , federalism was part of a "Constitution in exile." ${ }^{1}$ Except for the brief interlude of the National League of Cities doctrine ${ }^{2}$ - which, like Napoleon's ill-fated return from Elba, met with crushing defeat ${ }^{3}$ - the post-New Deal Supreme Court has been almost completely unwilling to enforce constitutional limits on national power vis-à-vis the states. ${ }^{4}$ The reason, by all accounts, has much to do with federalism's historic link to other aspects of our expatriate

Copyright (C) 2001 by Lynn A. Baker and Ernest A. Young.

$\dagger$ Thomas Watt Gregory Professor, University of Texas School of Law. B.A. 1978, Yale University; B.A. 1982, Oxford University; J.D. 1985, Yale Law School. E-mail: 1baker@mail.law. utexas.edu.

†† Assistant Professor, University of Texas School of Law. B.A. 1990, Dartmouth College; J.D. 1993, Harvard Law School. E-mail: eyoung@mail.law.utexas.edu.

This Article is based on a paper presented at the Constitution in Exile conference hosted by the Program in Public Law at Duke University School of Law on October 5-7, 2000. We are grateful to Chris Schroeder for inviting us and to the conference participants for their comments and questions. Special thanks to Ann Althouse, Frank Cross, Calvin Johnson, Neil Kinkopf, Susan Klein, Larry Kramer, Sandy Levinson, and Bob Young for their helpful comments, as well as to Richard Markovits and the student participants in his legal scholarship seminar. Cristina Carlucci, Chris Johns, Sean Keveney, Victoria Matthews, and Brenna Ryan provided excellent research assistance. We also like to take every chance we get to thank our spouses, Sam Dinkin and Allegra Young, for putting up with us generally.

1. By "Constitution in exile," we refer to the organizing metaphor of this conference.

2. See Nat'l League of Cities v. Usery, 426 U.S. 833, 852 (1976) (holding that generally applicable federal regulatory laws could not be enforced against state governments "in areas of traditional governmental functions").

3. See Garcia v. San Antonio Metro. Transit Auth., 469 U.S. 528, 531 (1985) (expressly overruling the National League of Cities doctrine).

4. It may be, as Professor Van Alstyne has observed, that this exile was not complete until Garcia's rejection of National League of Cities in 1985. William W. Van Alstyne, The Second Death of Federalism, 83 MicH. L. REV. 1709, 1722 (1985). Until Garcia, Van Alstyne argues, judicial enforcement of the Constitution's federalism provisions may have been very deferential to federal power, but the Court had never disavowed the power of review altogether. $I d$. 
constitution-e.g., economic substantive due process, legislative nondelegation-which were banished for their collusion against the New Deal.

The revival of federalism as a constitutional force in 1995 with the Supreme Court's decision in United States v. Lopez ${ }^{5}$ has spurred renewed efforts to link "states' rights" to the discredited aspects of the Court's pre-New Deal jurisprudence. Dissenting in Lopez, for example, Justice David Souter emphatically tied the Court's aggressive enforcement of Commerce Clause limits on federal power to the economic substantive due process of Lochner $v$. New York: ${ }^{6}$

The fulcrums of judicial review in [economic substantive due process] cases were the notions of liberty and property characteristic of laissez-faire economics, whereas the Commerce Clause cases turned on what was ostensibly a structural limit of federal power, but under each conception of judicial review the Court's character for the first third of the century showed itself in exacting judicial scrutiny of a legislature's choice of economic ends and of the legislative means selected to reach them.

Viewed in this light, the Lopez Court's holding that Congress had exceeded the limits of its commerce power entailed "a backward glance at both the old pitfalls" of the Lochner era. ${ }^{8}$ Nor is Justice Souter the only critic of Lopez and similar cases to ask whether the Rehnquist Court's revival of enforceable federalism limits on national power "portend[s] a return to the untenable jurisprudence from which the Court extricated itself almost 60 years ago."

5. 514 U.S. 549, 567 (1995) (invalidating the federal Gun-Free School Zones Act, 18 U.S.C. § 922 (1994), as beyond Congress's authority under the Commerce Clause). One might alternatively trace this "federalist revival," Vicki C. Jackson, Federalism and the Uses and Limits of Law: Printz and Principle?, 111 HARV. L. REV. 2180, 2213 (1998), to the Court's somewhat earlier decisions in New York v. United States, 505 U.S. 144, 174-188 (1992) (holding that Congress may not "commandeer" state legislatures by forcing them to enact laws), or Gregory $v$. Ashcroft, 501 U.S. 452, 470 (1991) (establishing a "clear statement rule" disfavoring statutory constructions that alter the federal balance).

6. 198 U.S. 45, 64 (1905) (striking down a state maximum-hours law for bakers as a violation of the "freedom of master and employee to contract" protected by due process).

7. Lopez, 514 U.S. at 606 (Souter, J., dissenting).

8. Id. at 608 .

9. Id. For similar concerns, see, e.g., Peter M. Shane, Federalism's "Old Deal": What's Right and Wrong with Conservative Judicial Activism, 45 VILL. L. REV. 201, 208 (2000); Dan Braveman, Enforcement of Federal Rights Against States: Alden and Federalism Non-Sense, 49 AM. U. L. ReV. 611, 656 (2000). See also John Gibbons, Our Federalism, 12 SufFolK U. L. REV. 1087, 1096-99 (1978) (making similar charges against earlier judicial enforcement of federalism). 
In this Article, we seek to respond to these concerns by asking whether federalism and economic substantive due process really belonged in constitutional exile together in the first place. The Supreme Court has not, of course, taken the Lochner experience as a cue to abandon the power of judicial review altogether. Instead, the Court simply has shifted its most searching judicial scrutiny from one class of cases, generally involving state and federal regulation of economic life, to others, involving free speech, personal privacy, and racial and gender equality. ${ }^{10}$ This shift is frequently described as "a double standard of judicial attitude, whereby governmental economic experimentation is accorded all but carte blanche by the courts, but alleged violations of individual civil rights are given meticulous judicial attention." 11

The very idea of double standards is problematic. As our colleague Douglas Laycock aptly insists, "we should take the whole Constitution seriously. We cannot legitimately pick and choose the clauses we want enforced." ${ }^{12}$ Without losing sight of this point, we mostly will set it aside for purposes of this Article. ${ }^{13}$ The fact is that for much of the last century, the Supreme Court, with widespread academic support, has behaved as if "constitutional provisions are like the animals in George Orwell's barnyard: some are considerably

10. For recent examples, pointing in both "conservative" and "liberal" directions, see, e.g., Stenberg v. Carhart, 530 U.S. 914, 945-46 (2000) (striking down a state ban on "partial birth" abortion procedures); Boy Scouts of America v. Dale, 530 U.S. 640, 659 (2000) (holding that a state antidiscrimination law violated the constitutionally protected freedom of association); United States v. Virginia, 518 U.S. 515, 558 (1996) (holding that state operation of a single-sex military academy violated the Equal Protection Clause); Romer v. Evans, 517 U.S. 620, 635 (1996) (striking down a state constitutional provision disadvantaging homosexuals); Rosenberger v. Rector of the University of Virginia, 515 U.S. 819, 845-46 (1995) (striking down, under the Free Speech Clause, a state university program that excluded religious publications from receiving school funds); Adarand Constructors, Inc. v. Pena, 515 U.S. 200, 227 (1995) (striking down a federal affirmative action program for racial minorities); R.A.V. v. City of St. Paul, 505 U.S. 377, 396 (1992) (holding that the First Amendment precluded prosecution for cross burning). See also Griswold v. Connecticut, 381 U.S. 479, 486 (1965) (recognizing a constitutionally protected right to privacy); Brown v. Bd. of Educ., 347 U.S. 483, 495 (1954) (holding that racially segregated public schools violate the Equal Protection Clause).

11. Henry J. Abraham, Freedom and the Court: Civil Rights and Liberties in THE UNITED STATES 10 (4th ed. 1982) (emphasis added).

12. Douglas Laycock, Equal Citizens of Equal and Territorial States: The Constitutional Foundations of Choice of Law, 92 COLUM. L. REV. 249, 267 (1992); see also Sanford Levinson \& Ernest A. Young, Who's Afraid of the Twelfth Amendment? 29 FLA. ST. U. L. REV. (forthcoming 2001) (manuscript at 44-45, on file with the Duke Law Journal) (suggesting "plausible reasons to treat all constitutional violations as equally worthy of concern").

13. But see infra Part II.C (suggesting that the same judicial competence issues that make courts reluctant to enforce federalism also ought to militate against judicial articulation of double standards). 
more equal than others." ${ }^{, 14}$ What we want to explore in this Article is why the Constitution's principles of federalism have been grouped with the goats rather than the sheep.

The question, in other words, is whether federalism belongs on the judicial desuetude side of the Court's double standard. The double standard was developed for three distinct sets of reasons: concerns about the institutional competence of courts to answer the sort of questions raised by economic substantive due process and similar doctrines; views about the necessity of judicial review in certain areas in contrast to relying on political safeguards for protection of some constitutional values; and widely held attitudes about the relative importance of personal or cultural liberties vis-à-vis economic ones. We contend that none of these criteria favors judicial nonenforcement of federalism limitations on national power. There is no reason to think, for example, that judges are less competent to develop workable doctrinal rules of federalism than they are with respect to, say, the right to privacy. Nor is it obvious that political safeguards provide adequate protection for federalism but inadequate protection for individual rights. Finally, we reject the notion that federalism limits should be regarded as less important than personal rights; indeed, the very reason for having the former is to protect the latter. Whether other portions of the Constitution ought to remain in exile-and we take no position on that question here-the federalism provisions should not. ${ }^{15}$

14. Levinson \& Young, supra note 12 (manuscript at 47) (paraphrasing GEORGE ORWELL, ANIMAL FARM 123 (1946)).

15. We use the term "federalism provisions" loosely to cover a wide range of both textual provisions and structural principles. The first category includes provisions clearly meant to limit the central government's authority, such as the Tenth and Eleventh Amendments; grants of enumerated powers to Congress that also, some argue, contain implicit limits on those powers, see, e.g., Lynn A. Baker, The Spending Power and the Federalist Revival, 4 CHAP. L. REV. 195 (2001) [hereinafter Baker, Spending Power] (arguing that the Spending Clause both grants and limits Congress's power); Gary Lawson \& Patricia B. Granger, The "Proper" Scope of Federal Power: A Jurisdictional Interpretation of the Sweeping Clause, 43 DUKE L.J. 267 (1993) (making a similar argument about the Necessary and Proper Clause); provisions that explicitly or implicitly limit state authority, such as the Supremacy Clause or the dormant Commerce Clause, see, e.g., Gibbons v. Ogden, 22 U.S. (9 Wheat.) 1 (1824) (recognizing a "dormant" aspect of the Commerce Clause limiting state regulatory authority); Laycock, supra note 12, at 250-51 (arguing that the Privileges and Immunities and Full Faith and Credit Clauses of Article IV significantly constrain the choice-of-law rules that states may apply); individual rights provisions that, some say, also include a federalism component, see AKHIL REED AMAR, THE BILL OF RIGHTS: CREATION AND RECONSTRUCTION 36-41, 76, 88-93 (1998); and even some provisions that clearly have something to do with federalism, although it has always been unclear exactly what, see, e.g., Deborah Jones Merritt, The Guarantee Clause and State Autonomy: Federalism for a Third Century, 88 Colum. L. REv. 1, 36-70 (1988) (exploring the federalism aspects of the 
One problem with framing our argument in terms of the double standard that arose after 1937 is that the content of that standard remains obscure. Part I of this Article thus attempts to pin down the precise content of that standard and to uncover the most plausible justifications for it. Part II addresses the double standard's competence rationale, concluding that judges face similar difficulties in all areas where the constitutional text provides little precise guidance. The fact that federalism is one of these areas-like the right to privacy or even free speech-does not justify the abdication of judicial responsibility for enforcing limits on national power vis-à-vis the states any more than it would justify a refusal to enforce these other rights. The competence criterion may, however, provide some guidance concerning how the articulation of federalism doctrine ought to proceed.

In Part III we turn to the necessity rationale. Although this Article is not the place to resolve the general debate concerning the "political safeguards of federalism," "we argue that that theory offers neither an accurate account of the double standard's distinction between what is enforced and what is not, nor adequate protection for the states within our constitutional system. Finally, Part IV argues that federalism concerns are intimately connected to the sort of individual rights that receive vigorous protection under the double standard. Any perceived opposition between individual rights and states' rights is a product of contingent historical facts of questionable current relevance. Indeed, recent history is replete with examples in which state autonomy is not a barrier to, and is in fact essential for, the mainte-

Twelfth Amendment). The second category-structure-includes principles derived from the original understanding of what a "state" is, see Michael B. Rappaport, Reconciling Textualism and Federalism: The Proper Textual Basis of the Supreme Court's Tenth and Eleventh Amendment Decisions, 93 Nw. U. L. REV. 819 (1999); from eighteenth-century political theory, see Ernest A. Young, Alden v. Maine and the Jurisprudence of Structure, 41 WM. \& MARY L. REV. 1601 (2000) [hereinafter Young, Jurisprudence of Structure]; and from the practical needs of a federal system, see CHARLES L. BLACK, JR., STRUCTURE AND RELATIONSHIP IN CONSTITUTIONAL LAW 8-22 (1969). This nonexhaustive list is worth pausing over simply to appreciate the vast range of issues that fall under the heading of "federalism and judicial review."

16. Compare, e.g., Herbert Wechsler, The Political Safeguards of Federalism: The Role of the States in the Composition and Selection of the National Government, 54 COLUM. L. REV. 543, 545 (1954) (arguing that political checks on federal power lessen the need for judicial review of federalism issues), and Larry D. Kramer, Putting the Politics Back into the Political Safeguards of Federalism, 100 Colum. L. REv. 215, 219 (2000) [hereinafter Kramer, Political Safeguards] (updating the arguments in Wechsler), with Lynn A. Baker, Putting the Safeguards Back into the Political Safeguards of Federalism, 46 VILL. L. REV. 951 (2001) [hereinafter Baker, Safeguards] (defending judicial review of federalism issues), and Saikrishna B. Prakash \& John C. Yoo, The Puzzling Persistence of Process-Based Federalism Theories, 79 TEX. L. REV. 1459 (2001) (same). 
nance of individual liberty. Interestingly, state autonomy also may be an important means of preserving the governmental regulatory discretion in economic matters that is likewise permitted under the double standard.

\section{Choosing THE EXILEs: 1937 AND THE DOUbLE STANDARD}

Although most constitutional law aficionados would agree that there is a double standard in the post-1937 case law, ${ }^{17}$ that consensus might evaporate when one asks the next logical question: a double standard between what and what? In this Part, we seek to define the areas in which the Court continues to engage in active judicial review and those in which it practices near-total deference to political decisionmakers. To chart this divide is, in essence, to identify which aspects of the Constitution are currently in exile and which aspects are not. We then seek the justifications for this divide as a guide for determining on which side of the divide federalism should fall.

\section{A. A Double Standard Between What and What?}

The double standard's locus classicus is Justice Stone's famous footnote four in Carolene Products ${ }^{18}$ which contains at least three different ways of framing the divide as well as some justifications for it. Justice Stone first articulated a general rule of judicial deference to legislative judgments - a "presumption of constitutionality" whereby "regulatory legislation affecting ordinary commercial transactions is not to be pronounced unconstitutional unless in the light of the facts made known or generally assumed, it is of such a character as to preclude the assumption that it rests upon some rational basis within the knowledge and experience of the legislators." ${ }^{\text {"T }}$ This presumption turned out to be powerful indeed, and more recent articulations of

17. See, e.g., ABRAHAM, supra note 11, at 13 (articulating the economic/social dichotomy); Gerald GunTHER \& KATHLEEN M. Sullivan, Constitutional LaW 530 (13th ed. 1997) ("What is clear in Griswold ... is that all of the Justices in the majority found some ordering of constitutional values justified...."); Alex Kozinski, Foreword to ECONOMIC LIBERTIES AND THE JUDiCIARY xiii (James A. Dorn \& Henry G. Manne eds., 1987) ("For the last 50 years or so ... courts have tended to treat certain rights differently from others.").

18. United States v. Carolene Prods. Co., 304 U.S. 144, 152 n.4 (1937); see, e.g., Robert G. McCloskey, Economic Due Process and the Supreme Court: An Exhumation and Reburial, 1962 SUP. CT. REV. 34, 45 (observing that "the modern Court ... has fairly consistently held to the 'dual standard' enunciated by Stone in the Carolene Products case").

19. Carolene Prods., 304 U.S. at 152. 
this rational basis standard continue to frame it as a test that the government generally cannot fail. ${ }^{20}$

Justice Stone's celebrated footnote allowed, however, that such deference might not be appropriate in other kinds of cases. The footnote's first paragraph suggested a textual distinction between enumerated and unenumerated rights:

There may be narrower scope for operation of the presumption of constitutionality when legislation appears on its face to be within a specific prohibition of the Constitution, such as those of the first ten amendments, which are deemed equally specific when held to be embraced within the Fourteenth. ${ }^{21}$

Commentators have since embraced this rationale for the Court's willingness to enforce some constitutional values but not others. Henry Abraham, for example, notes that "[t]he economicproprietarian safeguards of the Bill [of Rights] are couched in the most general of terms" while "the language governing what we commonly regard as our basic human freedoms is not only explicit, it is categorical!"’22

The appeal of this textual distinction seems superficial at best. As Professor Abraham acknowledges, the "categorical" language of the First Amendment has not led us to adopt the absolutist position of Justice Hugo Black. ${ }^{23}$ The wondrous complexity of free speech doctrine-endless distinctions between "commercial" and "political" speech, or among "viewpoint-based," "content-based," and "time, place, and manner" restrictions-is no more derivable from the text of the First Amendment than "freedom of contract" is derivable from the text of the Due Process Clause..$^{24}$ More importantly, the Constitution contains protections for economic rights which are no less ex-

20. See, e.g., Ferguson v. Skrupa, 372 U.S. 726, 733 (1963) (Harlan, J., concurring) (noting that he would uphold a state measure because it "bears a rational relation to a constitutionally permissible objective"); Williamson v. Lee Optical Co., 348 U.S. 483, 488 (1955) ("The day is gone when this Court uses the Due Process Clause of the Fourteenth Amendment to strike down state laws, regulatory of business and industrial conditions, because they may be unwise, improvident, or out of harmony with a particular school of thought.").

21. Carolene Prods., 304 U.S. at 152 n.4.

22. ABRAHAM, supra note 11, at 22-23.

23. Id. at 23. For Justice Black's views, see, e.g., Hugo Black, The Bill of Rights, 35 N.Y.U. L. REV. 865, 874 (1960) ("Neither as offered nor as adopted is the language of this Amendment anything less than absolute.").

24. See, e.g., Denver Area Educ. Telecomms. Consortium, Inc. v. FCC, 518 U.S. 727, 77778 (1996) (Souter, J., concurring) (explaining that First Amendment doctrine evolves in response to changing social and technological realities). 
plicit than the strictures of the Bill of Rights. The textually explicit nature of the Contract Clause, for example, has not saved that provision from exile. ${ }^{25}$ And of course the Court aggressively has protected areas of noneconomic due process that are every bit as textually suspect as the repudiated doctrine of Lochner $v$. New York. ${ }^{26}$

Perhaps Justice Stone's passage should be read not so much as emphasizing textual specificity per se, but rather the particular kind of textual provision at issue. That would suggest a distinction between individual rights - to which Stone primarily seemed to refer $^{27}$-and the Constitution's structural provisions. Jesse Choper, for example, urges that the Court should conserve its political capital for individual rights cases by treating structural issues of federalism or separation of powers as nonjusticiable. ${ }^{28}$ Whatever the normative merits of such a proposal, it does not track the Court's actual decisions. Lochner itself, after all, purported to protect an individual right to freedom of contract, ${ }^{29}$ and the Court's continuing willingness to adjudicate separation of powers issues belies any general abandonment of structural imperatives. $^{30}$

25. See Home Building \& Loan Ass'n v. Blaisdell, 290 U.S. 398, 447-48 (1934) (holding that a Minnesota act that extended time for recovery of property from foreclosure did not violate the Contract Clause).

26. See, e.g., Roe v. Wade, 410 U.S. 113, 166 (1973) (recognizing a woman's right to an abortion); Griswold v. Connecticut, 381 U.S. 479, 485-86 (1965) (recognizing a right to birth control devices for married couples).

27. Of course, the "first ten amendments" inconveniently includes the Tenth Amendment, which speaks in terms of states rather than individuals. Moreover, as Akhil Amar has demonstrated, several other provisions of the Bill of Rights had important federalism aspects. See AMAR, supra note 15 , at 36-41, 76, 88-93.

28. Jesse H. Choper, Judicial Review and the National Political Process: A Functional ReConsideration of THE Role of the Supreme Court 380 (1980). As an apparent exception to his distaste for structural claims, Dean Choper did propose that "the Supreme Court should pass final constitutional judgment on questions concerning the permissible reach and circumscription of "the judicial power."' Id. at 382-83. His enthusiasm for Article III claims, however, seems motivated in large part by their relationship to the protection of individual rights. See id. at 389-93.

29. See also Blaisdell, 290 U.S. at 447 (disregarding an individual right to nonimpairment of contracts). As Judge Learned Hand observed well after the Court's abandonment of economic due process, "Just why property itself was not a 'personal right' nobody took the time to explain.” LEARNED HAND, THE SPIRIT OF LIBERTY 206 (1960).

30. See, e.g., Bowsher v. Synar, 478 U.S. 714, 736 (1986) (striking down the GrammRudman-Hollings Act's balanced budget procedure); INS v. Chadha, 462 U.S. 919, 959 (1983) (striking down a legislative veto); Northern Pipeline Constr. Co. v. Marathon Pipe Line Co., 458 U.S. 50, 88 (1982) (striking down a provision creating non-Article III bankruptcy courts); Youngstown Sheet \& Tube Co. v. Sawyer, 343 U.S. 579, 588-89 (1952) (invalidating an executive order authorizing the Secretary of Commerce to seize steel mills). 
The Carolene footnote mentioned two additional bases for more searching judicial review:

It is unnecessary to consider now whether legislation which restricts those political processes which can ordinarily be expected to bring about repeal of undesirable legislation, is to be subjected to more exacting judicial scrutiny under the general prohibitions of the Fourteenth Amendment than are most other types of legislation....

Nor need we inquire ... whether prejudice against discrete and insular minorities may be a special condition, which tends seriously to curtail the operation of those political processes ordinarily to be relied upon to protect minorities, and which may call for a correspondingly more searching judicial inquiry. ${ }^{31}$

Taken together, these two paragraphs express a central concern with maintaining the accountability of the political process and correcting for distortions within that process that may disadvantage particular groups. That concern forms the basis of John Hart Ely's famous "representation reinforcement" theory of judicial review. ${ }^{32}$ But the Court's decisions frequently fail to track the divide that such a theory would suggest. Decisions like Griswold v. Connecticut, ${ }^{33}$ Roe v. Wade, ${ }^{34}$ and United States $v$. Virginia ${ }^{35}$ involve aggressive judicial review on behalf of interests that are well represented within contemporary political processes, ${ }^{36}$ perhaps even more striking, cases like Board of Education of Kiryas Joel Village School District v. Grumet ${ }^{37}$ and Boy Scouts of America v. Dale ${ }^{38}$ have struck down majority attempts to benefit particular minority groups. And in many cases, the Court has been reluc-

\footnotetext{
31. Carolene Prods., 304 U.S. at 152-53 n.4.

32. John Hart Ely, Democracy and Distrust: A Theory of Judicial ReVIEW (1980).

33. 381 U.S. 479, 485-86 (1965) (striking down a state restriction on the use of contraceptives by married couples).

34. 410 U.S. 113, 166 (1973) (striking down a state law infringing upon a woman's right to an abortion).

35. 518 U.S. 515, 558 (1996) (holding that Virginia could not exclude women from a public military academy).

36. See also Adarand Constructors, Inc. v. Pena, 515 U.S. 200, 227 (1995) (striking down a federal program designed to aid minority subcontractors on the ground that it discriminated against whites). Cases like Adarand demonstrate that the Court's promajority activism is not confined to "liberal" causes like abortion.

37. 512 U.S. 687, 709-10 (1994) (striking down, as a violation of the Establishment Clause, the New York legislature's attempt to accommodate the distinctive culture of the Satmar Hasidim by creating a separate public school district made up primarily of members of the sect).

38. 530 U.S. 640, 659 (2000) (holding that a New Jersey statute barring discrimination against gays in public accommodations violated the Boy Scouts' freedom of (non)association).
} 
tant to protect minorities from economic or social legislation that imposes disproportionate burdens on members of minority groups. ${ }^{39}$ Like Dean Choper's theory, Dean Ely's view has had more force as a normative position than as a description of the way the double standard actually has evolved.

Perhaps the double standard simply separates economic regulation from all other sorts of government action. ${ }^{40}$ Certainly this seems to have been the basic aim of the judicial revolution of 1937-that is, to facilitate and legitimate the government's expanded regulatory authority over the economy embodied in the New Deal. But even here there are problems. Judicial review of state economic legislation under the dormant Commerce Clause, for example, has continued to be considerably more aggressive than the Court's modern treatment of economic substantive due process. ${ }^{41}$ And the gradually expanding protection of commercial speech similarly has required more searching judicial review of economic regulation than conventional views of the double standard would prescribe. ${ }^{42}$ These two lines of cases reflect the fact that economic regulation may affect constitutional values-

39. See, e.g., Employment Div. v. Smith, 494 U.S. 872, 890 (1990) (holding that the Free Exercise Clause did not require an exemption from state narcotics laws for religious peyote users); McCleskey v. Kemp, 481 U.S. 279, 319 (1987) (rejecting a challenge to a capital sentencing scheme alleged to have disproportionately resulted in the execution of black defendants); Washington v. Davis, 426 U.S. 229, 248 (1976) (rejecting a challenge to a police officer qualification exam based on claims that higher percentages of blacks than whites failed the test).

40. See, e.g., Kozinski, supra note 17, at xiii (noting that although courts have protected some rights vigorously, "[g]overnment has been given a free hand to create, destroy, and adjust individual rights in the economic sphere"); Alan J. Meese, Will, Judgment, and Economic Liberty: Mr. Justice Souter and the Mistranslation of the Due Process Clause, 41 WM. \& MARY L. REV. 3, 4 (1999) (discussing "the distinction drawn by modern constitutional doctrine between economic liberties and so-called personal rights").

41. See, e.g., Fulton Corp. v. Faulkner, 516 U.S. 325, 346-47 (1996) (striking down a North Carolina tax on the value of corporate stock on the ground that it taxed foreign-owned corporations at a higher rate); C\&A Carbone, Inc. v. Clarkstown, 511 U.S. 383, 394 (1994) (striking down a local scheme to encourage private construction of a local waste transfer station on the ground that it discriminated against out-of-state waste processors); Kassel v. Consol. Freightways Corp., 450 U.S. 662, 678 (1981) (striking down an Iowa restriction on the length of trucks on state highways on the ground that it imposed an excessive burden on interstate commerce).

42. See, e.g., Lorillard Tobacco Co. v. Reilly, 121 S. Ct. 2404, 2430 (2001) (striking down a Massachusetts regulation dealing with the location of tobacco ads on the ground that it violated the First Amendment); United States v. United Foods, Inc., 121 S. Ct. 2334, 2337 (2001) (striking down mandatory assessments on mushroom producers to pay for a mushroom marketing campaign under the federal Mushroom Promotion, Research, and Consumer Information Act, 7 U.S.C. § 6101 (1994), as violating the producers' free speech rights); 44 Liquormart, Inc. v. Rhode Island, 517 U.S. 484, 516 (1996) (striking down a Rhode Island prohibition on alcohol price advertisements under the First Amendment). 
e.g., national unity, individual autonomy-with an importance transcending the economic sphere. ${ }^{43}$

These observations suggest that the double standard may not be reducible to a single coherent formulation and that it may derive more from history than from principle. Robert McCloskey, for example, speculates that the double standard "was never really thought through. It seems to have been a kind of reflex, arising out of indignation against the excesses of the Old Court, and resting on the vague, uncritical idea that 'personal rights' are 'O.K.' but economic rights are 'Not O.K." "44 To the extent that the Court's differential enforcement of various constitutional provisions is historically contingent, we suggest that historical circumstances no longer support-if they ever did-placing federalism in the "do not enforce" category.

Despite the difficulty of arriving at a coherent definition of the double standard, courts and commentators have attempted to justify it in principle, and these justifications are useful tools for thinking about whether federalism should remain in constitutional exile. We consider some of those justifications in the next Section.

\section{B. Justifying the Double Standard}

The most important justifications for a judicial double standard arise out of several of the different formulations of that standard that we explored in the previous Section. One such justification emphasizes institutional concerns about judicial competence to second-guess legislative judgments in particular areas. ${ }^{45}$ Justice Stone's reference to the specific provisions of the Bill of Rights, for example, reflects the fact that judges are generally more comfortable overriding majoritarian choices if they have a relatively determinate text in which to ground their decisions. The abandonment of Lochner's freedom of

43. See also Turner Broad. Sys., Inc. v. FCC, 512 U.S. 622, 663 (1994) (recognizing that legislation designed to influence the structure of communications markets has important free speech implications); Katzenbach v. McClung, 379 U.S. 294, 304-05 (1964) (recognizing that equal access to traditional commercial transactions-like buying a meal or renting a hotel room-may be an important aspect of social equality generally); Heart of Atlanta Motel, Inc. v. United States, 379 U.S. 241, 261 (1964) (same); McCloskey, supra note 18, at 55 ("From the first the modern Court has been troubled by a recurring problem: how does the dichotomy stand up when economic matters and personal rights are involved in a single governmental action?"); Ernest A. Young, Dual Federalism, Concurrent Jurisdiction, and the Foreign Affairs Exception, 69 GEO. WASH. L. REV. 139, 165 (2001) [hereinafter Young, Dual Federalism] (arguing that it is impossible to distinguish exclusive spheres of "commercial affairs" and "individual rights").

44. McCloskey, supra note 18 , at 54 .

45. See id. at 52-54 (describing and criticizing the "judicial capacity" argument for a double standard between economic and personal rights). 
contract and related doctrines, on the other hand, is surely traceable (at least in part) to the obverse concern-that is, that the judicially crafted standards under those doctrines were so indeterminate as to invite policy judgments the Court had neither the expertise nor the popular mandate to make. ${ }^{46}$

A second set of justifications, implicit in the second and third aspects of the Carolene Products footnote, relate to the perceived necessity of judicial review in particular areas. Many, if not most, discussions of judicial review in the twentieth century have perceived judicial override of actions by the political branches as an exceptional act requiring special justification. ${ }^{47}$ That justification is lacking-so the argument goes-when the political branches can be counted upon to protect the constitutional values at stake even in the absence of judicial intervention. ${ }^{48}$ Justice Stone thus advocated deferential review where the government neither had sought to constrain free political debate nor had isolated politically powerless minorities; ${ }^{49}$ others, however, have expanded the case for deference to those aspects of the structural constitution-particularly federalism and separation of powers-where particular institutions have political means of fending off invasions of their authority. ${ }^{50}$

The final set of justifications seeks to identify a set of preferred rights entitled to special judicial protection on normative grounds. On this view, economic substantive due process and states' rights simply are not as attractive normatively as the rights that the judiciary has been willing to enforce aggressively since 1937. Such arguments generally emphasize the centrality of free speech, personal privacy, or racial equality to the autonomy and dignity of individual human beings or some other normative theory of justice. ${ }^{51}$

As we indicated in the preceding Section, neither we nor the courts have a settled definition of the double standard, and these jus-

46. See United States v. Lopez, 514 U.S. 549, 607 (1995) (Souter, J., dissenting) (observing that, after 1937, "under commerce, as under due process, adoption of rational basis review expressed the recognition that the Court had no sustainable basis for subjecting economic regulation as such to judicial policy judgments").

47. E.g., Alexander M. Bickel, The Least Dangerous Branch: The Supreme COURT AT THE BAR OF POlitics 16-18 (1962); Ely, supra note 32, at 4-5; Robert H. Bork, Neutral Principles and Some First Amendment Problems, 47 IND. L.J. 1, 2-3 (1971).

48. E.g., ELY, supra note 32, at 101-02.

49. United States v. Carolene Prods. Co., 304 U.S. 144, 152 n.4 (1937).

50. E.g., CHOPER, supra note 28, at 382-83; Wechsler, supra note 16, at 543.

51. But see McCloskey, supra note 18, at 45-50 (describing and criticizing this argument for the double standard between economic and personal rights). 
tifications tend to map rather imperfectly onto any of the likely candidates. Nonetheless, these three sets of arguments provide a framework for evaluating whether, in a world of double standards, federalism belongs in the category of judicial nonenforcement. The conventional wisdom for over fifty years has been that it does. That consensus, however, has been asserted more frequently than examined. In the next three Parts, we argue that none of these conventional arguments provides a persuasive basis for distinguishing federalism from the constitutional values that the federal judiciary has proven willing to enforce.

\section{THE COMPETENCE PROBLEM}

The Court's abandonment of many aspects of federalism after $1937^{52}$-in particular, the Court's refusal to enforce substantive limits on the scope of Congress's commerce power-is often justified in terms of institutional concerns about judicial competence. Dissenting in United States v. Morrison, ${ }^{53}$ for example, Justice Souter direly warned of "the portent of incoherence" concerning any attempt to develop meaningful doctrinal limits on the commerce power. ${ }^{54}$ In a separate dissent, Justice Breyer invoked "the difficulty of finding a workable judicial Commerce Clause touchstone-a set of comprehensible interpretive rules that courts might use to impose some meaningful limit, but not too great a limit, upon the scope of the legislative authority that the Commerce Clause delegates to Congress."

These arguments draw their persuasive power from an extended history of judicial efforts to define and monitor exclusive spheres of state and federal regulatory authority. ${ }^{56}$ Certainly the graveyard of failed distinctions that these efforts left behind-"commerce" versus "police" regulation, "inherently national" versus "inherently local"

52. It is important to remember that the federal courts' commitment to judicial enforcement of many important pillars of the federal system-such as the primacy of state law in the absence of federal legislation, see Erie R.R. Co. v. Tompkins, 304 U.S. 64, 79 (1938), and the state courts' control over the content of that law, see Murdock v. City of Memphis, 87 U.S. (20 Wall.) 590, 636 (1875) -remains intact.

53. 529 U.S. 598, 627 (2000) (striking down the federal Violence Against Women Act, 42 U.S.C. $§ 13981$ (1994), as outside the limits of Congress's power under the Commerce Clause and Section Five of the Fourteenth Amendment).

54. Id. at 647 (Souter, J., dissenting).

55. Id. at 656 (Breyer, J., dissenting).

56. See generally Young, Dual Federalism, supra note 43, at 146-50 (recounting the various doctrinal fits and starts in this area).

57. Gibbons v. Ogden, 22 U.S. (9 Wheat.) 1, 11 (1824). 
matters ${ }^{58}$ "manufacturing" or "mining" versus "commerce," "direct" versus "indirect" effects ${ }^{60}$ - does not speak well for the judicial ability to develop doctrinal limits on national power that are at once meaningful and workable. But the question is not whether a revival of these failed doctrines would be a good thing; as one of us has argued at length elsewhere, the Court's modern federalism decisions for the most part make no attempt to reinvigorate the discredited doctrines of "dual federalism." ${ }^{\text {"61 }}$ Rather, the issue for the present day is whether the Court is somehow institutionally incapable of fashioning new rules that would constrain Congress while at the same time constraining the courts. ${ }^{62}$

In answering that question, it is instructive to look to the present fate of dual federalism's pre-1937 partner in crime: substantive due process. Certainly similar charges of institutional incapacity were made about Lochner and its progeny; critics have argued that doctrinal formulae like "freedom of contract" were insufficiently constraining to prevent the judges from simply enforcing their own policy preferences for laissez-faire economics. ${ }^{63}$ And yet, the Court has rehabilitated substantive due process in more recent years and used it to strike down a relatively wide range of social legislation. ${ }^{64}$ Critics of these more recent decisions have not hesitated to cry "Lochner!" or to doubt the institutional competence of the courts to render these

58. Cooley v. Board of Port Wardens, 53 U.S. (12 How.) 299, 319 (1852).

59. United States v. E.C. Knight Co., 156 U.S. 1, 14 (1895).

60. Id. at 17.

61. Young, Dual Federalism, supra note 43, at 153-67. "Dual federalism" held that the state and federal governments each possessed distinct "spheres" of regulatory authority in which their respective authority was exclusive, so that any intrusion by one level of government into the other's sphere was unconstitutional. E.g., id. at 143; see also, e.g., MARTIN H. REDISH, The Constitution As Political Structure 26 (1995) (contrasting "dual" and "cooperative" federalism); Edward S. Corwin, The Passing of Dual Federalism, 36 VA. L. REV. 1 (1950); John Kincaid, From Dual to Coercive Federalism in American Intergovernmental Relations, in Globalization and Decentralization 29, 29 (Jong S. Jun \& Deil S. Wright eds., 1996) ("Dual federalism was marked...[by] maintenance of the independent integrity of federal powers and state powers through separations of national and state spheres of action.").

62. See, e.g., Lawrence Lessig, Translating Federalism: United States v. Lopez, 1995 SuP. CT. REV. 125, 214 (arguing that the Court may need to develop new doctrines to preserve the original understanding of federalism under changed circumstances).

63. See, e.g., Brzonkala v. Virginia Polytechnic Inst., 169 F.3d 820, 890 (4th Cir. 1999) (Wilkinson, J., concurring) ("[C]ontemporary critics assailed the Court for indulging its 'judicial sense of what was good for the business community' and ignoring the plight of the common citizen.").

64. In addition to Griswold and Roe, see Stenberg v. Carhart, 530 U.S. 914, 945-46 (2000) (striking down a Nebraska ban on "partial birth" abortions); Troxel v. Granville, 530 U.S. 57, 73 (2000) (striking down a Washington grandparent visitation statute as a violation of the substantive due process rights of parents). 
judgments. ${ }^{65}$ And yet a fairly consistent majority of the Court-including, frequently, those Justices most incensed about the illegitimacy of judicial review in the federalism area ${ }^{66}$-generally has rejected judicial competence concerns when due process rights affecting personal autonomy are at stake. We begin this Part by assuming that the Court's reasons for rejecting competence concerns in substantive due process cases have merit; we then ask whether those reasons might also apply in federalism cases.

\section{A. Judicial Competence to Enforce Substantive Due Process: Justice Souter's Glucksberg Concurrence}

The most articulate recent defense of judicial capacity to formulate a workable doctrine in the area of noneconomic substantive due process is Justice Souter's concurrence in Washington v. Glucksberg. ${ }^{67}$ Glucksberg rejected a claim that Washington's ban on physicianassisted suicide violated a personal "right to die" grounded in the Due Process Clause. ${ }^{68}$ Although Justice Souter concurred in that judgment, he wrote an extended opinion defending the general principle of noneconomic substantive due process and exploring the circumstances in which courts ought to use such a theory to invalidate legislation restricting personal rights. While acknowledging the "breadth and indeterminacy of the 'due process' serving as the claim's textual basis," Justice Souter insisted that "[t]he persistence of sub-

65. E.g., Planned Parenthood v. Casey, 505 U.S. 883, 998 (1992) (Scalia, J., dissenting); John Hart Ely, The Wages of Crying Wolf: A Comment on Roe v. Wade, 82 YALE L.J. 920, 93743 (1973).

66. See, e.g., Stenberg, 530 U.S. at 945 (Breyer, J.) (writing for the majority in striking down a "partial birth abortion" ban); Casey, 505 U.S. at 901 (Souter, J.) (joining a joint opinion upholding the substantive due process right to an abortion); id. at 912 (Stevens, J., concurring in part and dissenting in part) (joining the joint opinion's reaffirmation of the substantive due process right discovered in Roe); see also BMW of N. Am., Inc. v. Gore, 517 U.S. 559, 585 (1996) (Stevens, J.) (writing for the majority and recognizing a substantive due process right to be free from excessive punitive damages); $i d$. at 587-88 (Breyer, J., concurring) (agreeing that "arbitrary" awards violate the Due Process Clause). To be fair, some critics of noneconomic substantive due process have likewise embraced judicial creativity when it comes to federalism. Compare Casey, 505 U.S. at 980 (Scalia, J., concurring in part and dissenting in part) (rejecting the substantive due process right to an abortion), with Printz v. United States, 521 U.S. 898, 935 (1997) (Scalia, J.) (writing for the majority and recognizing a nontextual anticommandeering doctrine to protect state autonomy).

67. 521 U.S. 702, 752-89 (1997); see, e.g., Meese, supra note 40, at 11 ("Justice Souter ... has offered the most sustained judicial defense to date of the distinction between economic and personal liberties.").

68. Glucksberg, 521 U.S. at 735. 
stantive due process in our cases points to the legitimacy" of the overall enterprise. $^{69}$

Justice Souter's defense of substantive due process in Glucksberg, which drew heavily on Justice Harlan's seminal dissent in Poe v. Ullman, ${ }^{70}$ emphasized three major points. First, he argued that the "enduring tradition" of substantive due process review is "nothing more than what is required by the judicial authority and obligation to construe constitutional text and review legislation for conformity to that text." ${ }^{71}$ To be sure, Justice Souter also emphasized concerns about "which institution, a legislature or a court, is relatively more competent to deal with an emerging issue as to which facts currently unknown could be dispositive." $72 \mathrm{He}$ acknowledged, however, that "[s]ometimes a court may be bound to act regardless of the institutional preferability of the political branches as forums for addressing constitutional claims." ${ }^{73}$ And nothing in Justice Souter's discussion of comparative institutional competence suggests that a court would ever be justified in abandoning the enforcement of particular constitutional principles altogether, without regard for the circumstances of individual cases. ${ }^{74}$

Second, Justice Souter echoed Justice Harlan's recognition that in performing the judicial function in substantive due process cases, there is no escape from the exercise of "reasoned judgment." "If "If the supplying of content to this Constitutional concept has of necessity been a rational process," Justice Harlan had written, "it certainly has not been one where judges have felt free to roam where unguided speculation might take them." "[n]o formula could serve as a substitute, in this area, for judgment

\footnotetext{
69. Id. at 756 (Souter, J., concurring).

70. 367 U.S. 497, 522 (1961) (Harlan, J., dissenting). The joint opinion in Planned Parenthood v. Casey, 505 U.S. 833, 848-49 (1992), adopted the reasoning of Justice Harlan's Poe dissent, just as Griswold v. Connecticut, 381 U.S. 479, 485-86 (1965), had adopted its result twentyseven years earlier. See also Glucksberg, 521 U.S. at 756 n.4 (Souter, J., concurring) (collecting other cases relying on the Poe dissent).

71. Glucksberg, 521 U.S. at 763 (Souter, J., concurring) (citing Marbury v. Madison, 5 U.S. (1 Cranch) (1803)).

72. Id. at 788 .

73. Id. (citing Bolling v. Sharpe, 347 U.S. 497 (1954)).

74. See also McCloskey, supra note 18, at 44 (arguing that the Court's post-1937 economic due process cases have never explained "why the deference to the legislature should be carried to the point of complete submission").

75. Glucksberg, 521 U.S. at 769 (Souter, J., concurring).

76. Poe v. Ullman, 367 U.S. 497, 542 (Harlan, J., dissenting).
} 
and restraint." ${ }^{77}$ The inability of judges to define analytically clean categories - to construct a perfectly consistent and coherent set of bright-line rules for all cases-thus does not justify abdication of the responsibility of judicial review.

Third, Justice Souter argued that the appropriate model for judicial development of legitimate and workable substantive due process doctrine is the common law method: ${ }^{78}$

[T] he usual thinking of the common law is suspicious of the all-ornothing analysis that tends to produce legal petrification instead of an evolving boundary between the domains of old principles. Common-law method tends to pay respect instead to detail, seeking to understand old principles afresh by new examples and new counterexamples. The "tradition is a living thing," ... albeit one that moves by moderate steps carefully taken. ${ }^{79}$

Under this common law method, workable doctrine emerges over time through the accumulation of individual decisions, even if the court cannot define a comprehensive test a priori. ${ }^{80}$

Justice Souter's Glucksberg concurrence characterized the pre1937 due process cases as "offer[ing] a substantive interpretation of 'liberty,' that in the aftermath of the so-called Lochner era has been scaled back in some respects, but expanded in others, and never repudiated in principle." " One can construct an equally valid claim by substituting "conception of federalism" for "substantive interpretation of 'liberty"' in that sentence. Like West Coast Hotel ${ }^{82}$ in the sub-

77. Id. Justice Souter also cited Justice Powell's statement for a plurality in Moore v. East Cleveland, 431 U.S. 494, 503 (1977), that "[a]ppropriate limits on substantive due process come not from drawing arbitrary lines but rather from careful 'respect for the teachings of history [and] solid recognition of the basic values that underlie our society." Glucksberg, 521 U.S. at 766 (Souter, J., concurring). Justice Powell was, in turn, quoting Griswold v. Connecticut, 381 U.S. 479, 501 (1965) (Harlan, J., concurring).

78. Glucksberg, 521 U.S. at 767 (Souter, J., concurring).

79. Id. at 770 (quoting Poe, 367 U.S. at 542 (Harlan, J., dissenting)).

80. See also Denver Area Educ. Telecomms. Consortium v. FCC, 518 U.S. 727, 777-78 (1996) (Souter, J., concurring) (arguing that free speech doctrine should proceed in this way under conditions of technological and regulatory uncertainty); David Strauss, Common Law Constitutional Interpretation, 63 U. CHI. L. REV. 877, 880 (1996) (discussing the common law method in constitutional interpretation); Ernest Young, Rediscovering Conservatism: Burkean Political Theory and Constitutional Interpretation, 72 N.C. L. REV. 619, 688-97 (1994) [hereinafter Young, Rediscovering Conservatism] (same).

81. 521 U.S. at 760 (Souter, J., concurring).

82. West Coast Hotel Co. v. Parrish, 300 U.S. 379, 399-400 (1937) (rejecting an economic substantive due process challenge to a state minimum wage law and overruling the Lochner-era decision in Adkins v. Children's Hospital, 261 U.S. 525 (1923)). 
stantive due process area, Jones \& Laughlin $^{83}$ did not alter the basic Commerce Clause analysis found in the pre-1937 case law; instead, the Court retained the principle of limited federal power and scaled back its application. The more emphatic affirmations of federal power that followed, particularly Wickard ${ }^{84}$ and Darby, ${ }^{85}$ likewise retained a commitment to federalism backed up by at least some threat of judicial enforcement.

Even Garcia $^{86}$ - which arguably marks the nadir of post-1937 federalism case law and was good law on the relevant point for an even shorter time than National League of Cities $^{87}$-never repudiated federalism in principle. "What has proved problematic," Justice Blackmun recognized, "is not the perception that the Constitution's federal structure imposes limitations on the Commerce Clause, but rather the nature and content of those limitations. ${ }^{, 89}$ As we explain, ${ }^{90}$ the Garcia Court rejected one particular approach to federalism doctrine-the attempt "to articulate affirmative limits on the Commerce Clause power in terms of core governmental functions and fundamental attributes of state sovereignty" — without attempting "to identify or

83. NLRB v. Jones \& Laughlin Steel Corp., 301 U.S. 1, 57 (1937) (upholding the National Labor Relations Act).

84. Wickard v. Filburn, 317 U.S. 111, 120 (1942) (upholding the Agricultural Adjustment Act's restrictions as applied to wheat grown by a single farm for home consumption, rather than for sale).

85. United States v. Darby, 312 U.S. 100, 117 (1941) (upholding the Fair Labor Standards Act's regulation of wages and hours and overruling the Lochner-era decision in Hammer v. Dagenhart, 247 U.S. 251 (1918)).

86. Garcia v. San Antonio Metro. Transit Auth., 469 U.S. 528, 531 (1985) (overruling National League of Cities and announcing that the political process is the primary safeguard for federalism).

87. Nat'l League of Cities v. Usery, 426 U.S. 833 (1976). Taking its cues from Garcia, the Court renewed its commitment to enforcing meaningful limits on national power just six years later in Gregory v. Ashcroft, 501 U.S. 452, 460-61 (1991) (imposing a clear-statement rule of statutory construction where federal statutes arguably could alter the state-federal balance), and again the next year in New York v. United States, 505 U.S. 144, 161 (1992) (holding that Congress may not compel state legislatures to adopt and enforce federal regulations). See also John C. Yoo, The Judicial Safeguards of Federalism, 70 S. CAL. L. REV. 1311, 1311-12 (1997) (arguing that Garcia is no longer good law).

88. See, e.g., Martha A. Field, Comment, Garcia v. San Antonio Metropolitan Transit Authority: The Demise of a Misguided Doctrine, 99 HARV. L. REV. 84, 110-11 (1985):

[T] he Court does not rule out all possibility of judicial intervention on behalf of states, as it might easily have done. It neither held that state sovereignty imposes no limits on Congress's exercise of delegated powers nor ruled that the political question doctrine, or some counterpart doctrine, commits the protection of state sovereignty solely to Congress.

89. Garcia, 469 U.S. at 547.

90. See infra notes $115-20$ and accompanying text.

91. Garcia, 469 U.S. at 556. 
define what affirmative limits the constitutional structure might impose on federal action affecting the States." ${ }^{92}$ Indeed, as with Justice Souter's characterization of the substantive due process cases, the Garcia Court even "expanded" its commitment to federalism in other ways by providing a theoretical basis for useful principles of "process federalism." ${ }^{, 3}$

That is what makes the claim of the current Court's nationalist Justices - that "the Constitution remits [federalism issues] to politics" ${ }^{\prime 4}$ - so extraordinary. And it is particularly ironic to hear this claim defended on judicial competence grounds by precisely those Justices who have made the most persuasive case for judicial creativity in the area of substantive due process. ${ }^{95}$ We think that those Justices were right the first time: the courts have a responsibility to exer-

92. Id.

93. See Andrzej Rapaczynski, From Sovereignty to Process: The Jurisprudence of Federalism After Garcia, 1985 SUP. CT. REV. 341, 364-65 (arguing that Garcia's emphasis on process still would permit quite searching forms of judicial review). To be sure, most of the legal community did not place such an optimistic (from the states' perspective) spin on Garcia. See, e.g., Edward L. Rubin \& Malcolm Feeley, Federalism: Some Notes on a National Neurosis, 41 UCLA L. REV. 903, 903 (1994) (reading Garcia as a "brave declaration that [the Court] had sworn off federalism for good"); Van Alstyne, supra note 4, at 1722-23 (noting that the Garcia court excused itself from judicial review of whether Congress's enumerated powers permit displacement of state legislation or directives). That view, it seems to us, is best ascribed to the probably accurate perception that the five members of the Garcia majority were not really serious about developing alternative protections for state autonomy. But see South Dakota v. Dole, 483 U.S. 203, 212 (1987) (Brennan, J., dissenting) (joining Justice O'Connor in arguing that Congress cannot use the Spending Clause to limit a right granted to the states under the Twenty-First Amendment). We would hesitate, however, to accord much precedential value to mere insincerity. Although the two of us might differ on how much protection "process federalism" ultimately can offer to states, we do not doubt that it may play an important role in some circumstances. See generally Ernest A. Young, Two Cheers for Process Federalism, 46 VILL. L. REV. 1349 (2001) [hereinafter Young, Two Cheers] (discussing the importance of process federalism in protecting the regulatory authority of states).

94. United States v. Morrison, 529 U.S. 598, 649 (2000) (Souter, J., dissenting).

95. In addition to Justice Souter's Glucksberg concurrence, see also Planned Parenthood v. Casey, 505 U.S. 833, 846-53 (1992) (Souter, J.) (coauthoring a joint opinion advocating the common law development of substantive due process rights to privacy and abortion); $B M W$ of N. Am., Inc. v. Gore, 517 U.S. 559, 587-97 (1996) (Breyer, J., concurring) (developing standards for judicial review of punitive damages awards under the Due Process Clause). The central questions of the abortion debate (Does human "life" begin at conception, at birth, or somewhere in between?) and the punitive damages debate (What damages are necessary to deter tortious behavior?) are not ones that courts ever have professed any particular competence to answer. Nor is this pattern confined to the Court's current nationalists. Compare, e.g., Nat'l League of Cities v. Usery, 426 U.S. 833, 867 (1976) (Brennan, J., dissenting) (suggesting that the majority's doctrine of protecting state sovereignty was so indeterminate as to simply be a mask for judicial policy judgments), with Michael H. v. Gerald D., 491 U.S. 110, 137-41 (1989) (Brennan, J., dissenting) (suggesting that the Court's grounding of fundamental rights in specific rather than general traditions unduly constrains the ability of courts to protect fundamental rights). 
cise "reasoned judgment" " even when bright-line rules are not available to enforce particular constitutional principles, and the common law method affords an opportunity for creative development of workable doctrine through "moderate steps carefully taken." develop this argument in the next Section.

\section{B. Federalism and Judicial Competence}

Both the obligation and ability of the courts to enforce the constitutional balance between the nation and the states become clear when we apply Justice Souter's Glucksberg analysis in the federalism context. ${ }^{98}$ The textual basis for principles of federalism in the Constitution is surely stronger than the textual basis for substantive due process. ${ }^{99}$ And the tradition of judicial enforcement of federalism, like that of substantive due process recounted in Glucksberg, is longstanding and persistent. ${ }^{100}$ It also seems obvious that when Justice

96. Washington v. Glucksberg, 521 U.S. 702,769 (1997) (Souter, J., concurring) (quoting Casey, 505 U.S. at 849).

97. Id. at 770. At least two sitting Justices explicitly have agreed on this point. See infra note 107 and accompanying text.

98. For another analysis arguing that constitutional interpretative methodologies pioneered in the substantive due process cases may be appropriate in the federalism context, see Brannon P. Denning \& Glenn Harlan Reynolds, Comfortably Penumbral, 77 B.U. L. REV. 1089, 1097 (1997) (finding that the majority has been willing to rely extensively on penumbral reasoning in recent decisions in the area of federalism).

99. See, e.g., Rappaport, supra note 15, at 821 (arguing that much of the Court's federalism doctrine can be grounded in original understandings of the word "state" as used in the Constitution); see also supra note 15 (listing additional sources).

100. See, e.g., McCulloch v. Maryland, 17 U.S. (4 Wheat.) 316, 423 (1819) (observing that "should Congress, under the pretext of executing its powers, pass laws for the accomplishment of objects not entrusted to the government; it would become the painful duty of this tribunal ... to say that such an act was not the law of the land"); Yoo, supra note 87, at 1313 (arguing that the Framers understood federalism to be judicially enforceable). Although Larry Kramer recently has questioned the frequency and relative importance to the Framers of judicial enforcement of federalism, see Kramer, Political Safeguards, supra note 16, at 234-52, his argument seems to be directed primarily to the pre-ratification period and is therefore relevant to the intentions of the Framers rather than the existence or nonexistence of a subsequent tradition of judicial review. See generally Young, Rediscovering Conservatism, supra note 80 (arguing that constitutional interpretation should take account of the entire arc of American history rather than merely a snapshot of what the Constitution was understood to mean in 1789). Kramer concedes, for example, that the Federalist contained strong statements relying on judicial review, see Kramer, Political Safeguards, supra note 16, at 247 (acknowledging that Federalist No. 78 was seen as setting out an aggressive nationalist position on judicial review), and that those essays "assumed [their] position in the front rank of sources to consult in interpreting the Constitution soon after Ratification," id. at 248 n.135. Moreover, Saikrishna B. Prakash and John C. Yoo appear to have identified much more extensive support for judicial review of federalism issues in the pre-ratification period than Professor Kramer has acknowledged. See Prakash \& Yoo, supra note 16 , at 1489-521. In any event, the tradition of judicial review in the federalism area is at worst no less robust than the sporadic early enforcement of substantive due process. See, e.g., 
Souter speaks of "the judicial authority and obligation to construe constitutional text and review legislation for conformity to that text," ${ }^{101}$ he is not suggesting that the text must speak particularly clearly - that is, that the judicial authority and obligation to enforce arise only for those principles enshrined in highly determinate language. Substantive due process, after all, hardly fits that category. ${ }^{102}$ If one is convinced that the Constitution embodies any binding principles of federalism at all $^{103}$ - a battle which must be fought elsewhere but which seems fairly lopsided to us-then enforcing them is part of the Justices' job description.

That judicial obligation, as Justice Souter's second point in Glucksberg appreciated, is not limited to "easy cases." 104 The fundamental rights protected by substantive due process are hardly selfdefining, and yet the Court has committed itself to the gradual elaboration of workable doctrine in this area. One finds a similar commitment throughout the sphere of post-1937 "preferred rights": are we

Washington v. Glucksberg, 521 U.S. 702, 756-60 (1997) (Souter, J., concurring) (surveying early instances of substantive due process review).

Professor Kramer also concedes that the Framers intended the Courts to play an important role in enforcing the aspect of federalism that protects the national government from encroachments. See Kramer, Political Safeguards, supra note 16, at 243 (noting that early constitutional reformers were very concerned about states' encroaching on federal authority). It would be strange, however, to create a double standard between enforcing the state and federal sides of the balance when the political safeguards arguments that form the centerpiece of Kramer's analysis, see id. at 278-87, would seem to apply equally to each, $c f$. infra note 105 and accompanying text (arguing that any competence problem associated with protection of states from the national government also affects judicial efforts to protect the national government from the states).

101. Glucksberg, 521 U.S. at 763 (Souter, J., concurring).

102. If anything, the Tenth Amendment's confirmation of the principle of limited federal powers is far clearer than any textual evidence of a substantive component in either Due Process clause.

103. One might read Justice Souter's dissent in Morrison as arguing that the Seventeenth Amendment essentially deleted federalism from the list of constitutional values. See United States v. Morrison, 529 U.S. 598, 650-52 (2000) (Souter, J., dissenting) (noting that the limitation of states' power was a well-known consequence of the Seventeenth Amendment among its Framers and arguing that there is no "justification for attempts to nullify the natural political impact" of the Amendment). We think this argument represents an unduly aggressive view of the Amendment. Scholars have suggested that the Framers and Ratifiers of the Seventeenth Amendment did not undertake a fundamental alteration of the federal system. See Vikram David Amar, Indirect Effects of a Direct Election: A Structural Examination of the Seventeenth Amendment, 49 VAND. L. REV. 1347, 1353-55 (1996) (concluding that the proponents of direct election did not focus on the federalism impact of their proposal). More generally, we would want to see a pretty clear statement in the text of an amendment before we would read it as working such a fundamental change. See also infra note 269 (discussing a similar argument concerning the effect of the Reconstruction Amendments).

104. Cf. Frederick Schauer, Easy Cases, 58 S. CAL. L. REV. 399, 414 (1985) (arguing that, in many situations, the constitutional text will indicate a single right answer). 
really prepared to say, for example, that the reason courts enforce the Free Speech Clause with such extraordinary vigor is that the judicially developed rules and categories in this area are so intrinsically workable and analytically clean? Nor has the difficulty of formulating workable rules deterred the federal courts from enforcing the side of federalism doctrine that limits state power, despite the fact that the incoherence of dormant Commerce Clause doctrine has been an open scandal for generations. ${ }^{105}$

In each of these areas-and indeed throughout constitutional law-the perceived importance of the constitutional principle at stake has led the judiciary to develop elaborate doctrinal structures through "reasoned judgment," even though the proper shape of those structures does not jump off the face of the constitutional text and even though the doctrine has required constant elaboration, adaptation, and even revision over time. To foreclose judicial review in all areas that challenge the institutional capacities of courts, as Professor McCloskey points out, "would be to abandon judicial review in most of the fields where it is now exercised." 106 Justice O'Connor thus recognized, in a recent speech on federalism, that "[w]hile reasonable minds may differ as to where those lines [between federal and state authority] are, line-drawing is the essence of law. The difficulty of the task is no cause to shrink from it." 107

A frank appraisal of the pervasive line-drawing problems throughout constitutional law suggests that the double standard must be defended-if it can be defended-on grounds other than judicial

105. See, e.g., Tyler Pipe Indus., Inc. v. Wash. State Dep't of Revenue, 483 U.S. 232, 265 (1987) (Scalia, J., dissenting) (complaining that, in the dormant Commerce Clause area, "the Court for over a century has engaged in an enterprise that it has been unable to justify by textual support or even coherent nontextual theory, that it was almost certainly not intended to undertake, and that it has not undertaken very well"); Jenna Bednar \& William N. Eskridge, Jr., Steadying the Court's "Unsteady Path": A Theory of Judicial Enforcement of Federalism, 68 S. CAL. L. REV. 1447, 1461-63 (1995) (discussing the Supreme Court's "vigorous" enforcement of the dormant Commerce Clause and describing the line of cases as "incoherent").

Personally, we have no particular problem with most of the extant dormant Commerce Clause doctrine-but that is because we think that the proper response to difficult doctrinal problems is not abdication but to make the best attempt one can and to be prepared to revise the doctrine later if the first try does not work out.

106. McCloskey, supra note 18, at 52 .

107. Sandra Day O'Connor, Altered States: Federalism and Devolution at the "Real" Turn of the Millennium, Sir David Williams Lecture Series, University of Cambridge Centre for Public Law 7 (May 15, 2001) (unpublished manuscript, on file with the Duke Law Journal); see also United States v. Lopez, 514 U.S. 549, 578 (1995) (Kennedy, J., concurring) ("[T] he federal balance is too essential a part of our constitutional structure and plays too vital a role in securing freedom for us to admit inability to intervene when one or the other level of Government has tipped the scales too far."). 
competence. ${ }^{108}$ Justice Souter's discussion in Glucksberg not only highlights the inescapable need for "reasoned judgment," but also points the way as to how such judgment should proceed. The Court never has articulated a comprehensive theory of substantive due process; instead, the doctrinal development in that area has been an incremental process of inclusion and exclusion. ${ }^{109}$ Justice Harlan's argument in Poe that the right to use contraceptives can be derived from the intersection of two lines of precedent—cases recognizing the sanctity of the marital relationship and cases recognizing a privacy interest in one's home-typifies this process. ${ }^{110}$

So, too, there is no reason to believe that a workable doctrine cannot emerge from the Court's recent efforts to define the limits of the federal commerce power. The Court's decisions in Lopez and Morrison, for example, represent a significant refinement of the pre1937 law in that they accept the principle of an integrated national market; rather than attempting to distinguish intra- from inter-state commerce, the Court's more recent decisions simply draw a line between what is "commercial" and what is not. ${ }^{111}$ The Court's refusal to

108. It is worth noting that the nationalist Justices' adamant opposition to federalism does not disappear in contexts that are more susceptible to bright-line rulemaking. Whatever else one might say against the Court's holding in Seminole Tribe v. Florida, 517 U.S. 44 (1996), the doctrinal rule that it announced-private individuals may not sue a state for money damages, regardless of the jurisdictional basis of the claim and regardless of Congress's attempts to override that immunity, $i d$. at 48 , is readily stated, analytically clean, and easy for a court to enforce. The existence of an exception to the general nonabrogation rule for valid congressional action under Section Five of the Fourteenth Amendment, see Fitzpatrick v. Bitzer, 427 U.S. 445, 456 (1976) (holding that Congress may decide to allow private suits against states or state officials), complicates the picture somewhat-but not much. And yet the absence of a colorable institutional competence objection has not lessened the vehemence of the nationalist Justices' dissents in this area. See, e.g., Kimel v. Fla. Bd. of Regents, 528 U.S. 62, 99 (2000) (Stevens, J., dissenting) (insisting that, notwithstanding stare decisis, Seminole Tribe "should be opposed whenever the opportunity arises"). We do not mean to suggest that the relative simplicity of the majority's position makes it correct; quite the contrary, one of us has argued that the majority has fallen into error by ignoring crucial complexities in the history of sovereign immunity. Young, Jurisprudence of Structure, supra note 15, at 1664-75.

109. See, e.g., Young, Rediscovering Conservatism, supra note 80, at 688-97 (discussing substantive due process as an example of common law constitutional development).

110. Poe v. Ullman, 367 U.S. 497, 543-44 (1961) (Harlan, J., dissenting) (tracing the broad outlines of the concept of liberty from Pierce v. Society of Sisters, 268 U.S. 510 (1925), to Skinner v. Oklahoma, 316 U.S. 535 (1942)); see also Denver Area Educ. Telecomms. Consortium, Inc., v. FCC, 518 U.S. 727, 776-78 (1996) (Souter, J., concurring) (arguing that the Court should not formulate categorical First Amendment rules for new media that are still in technological and regulatory flux; rather, the Court should allow doctrinal rules to emerge by reasoning from analogy rather than rule).

111. See Young, Dual Federalism, supra note 43, at 159 (discussing the acceptance of an integrated national market implicit in the Court's commercial/noncommercial distinction). 
frame this distinction in a categorical way, ${ }^{112}$ on the other hand, represents a recognition that further doctrinal refinement may be necessary. To the extent that this development traces an "unsteady path," that unsteadiness simply reflects the nature of common law incrementalism rather than the illegitimacy of the enterprise. ${ }^{114}$

The current Court's ongoing effort to develop workable federalism doctrines need not be inconsistent with the Garcia majority's rejection of one particular approach to the problem. Indeed, Justice Blackmun's opinion for the Garcia majority acknowledged that "[m]any constitutional standards involve 'undoubte[d] ... gray areas,' . . . and ... it normally might be fair to venture the assumption that case-by-case development would lead to a workable standard for determining whether a particular governmental function should be immune from federal regulation under the Commerce Clause." 115 The Court rejected this sort of common law development only because of particular difficulties with National League of Cities' "traditional governmental functions" test. ${ }^{116}$ One of us has argued elsewhere that federalism doctrine should generally avoid this sort of "traditional functions" test. ${ }^{117}$ That hardly establishes, however, that the judiciary lacks competence to engage in any sort of federalism review.

The problem is that the Garcia majority seemed to embrace a false dichotomy between a search for "elusive[] ... objective criteria for 'fundamental' elements of state sovereignty," 118 on the one hand, and complete reliance on the political process on the other. A variety

112. See United States v. Morrison, 529 U.S. 598, 613 (2000) (declining to adopt a categorical rule that the aggregation principle of Wickard v. Filburn, 317 U.S. 111 (1942), can never be used to support a regulation of noneconomic activity under the Commerce Clause).

113. Bednar \& Eskridge, supra note 105, at 1447; see also Matthew D. Adler \& Seth F. Kreimer, The New Etiquette of Federalism: New York, Printz, and Yeskey, 1998 SUP. CT. REV. 71,73 (criticizing the Court for not offering a theoretically coherent set of federalism doctrines).

114. See Ernest A. Young, State Sovereign Immunity and the Future of Federalism, 1999 SUP. CT. REv. 1, 34-38 [hereinafter Young, State Sovereign Immunity] (discussing various reasons why the development of federalism doctrine is likely to be incremental and not theoretically unified).

115. Garcia v. San Antonio Metro. Transit Auth., 469 U.S. 528, 540 (1985) (quoting Fry v. United States, 421 U.S. 542, 558 (1975) (Rehnquist, J., dissenting)).

116. See id. at 540-41 (citing "the Court's experience [with that test] in the related field of state immunity from federal taxation"). Even this narrow judgment may, of course, have been too harsh; as Andrzej Rapaczynski has observed, "Garcia's merciless critique of the criterion of tradition seems to evince a desire for watertight, mechanical tests of protected governmental functions that simply cannot be had in an area as complex as that of federalism." Rapaczynski, supra note 93 , at 415.

117. See Young, Dual Federalism, supra note 43, at 163-67 (arguing that courts should not seek to define exclusive zones of state autonomy).

118. Garcia, 469 U.S. at 548. 
of commentators on both sides of current federalism debates agree that these are not the only two options. Larry Kramer, for example, observes that "just because it's no longer possible to maintain a fixed domain of exclusive state jurisdiction it's not necessarily impossible to maintain a fluid one." ${ }^{119}$ It is as if the Court had said, with respect to substantive due process, that the difficulty of identifying fundamental individual rights of personal autonomy requires the rejection of any sort of substantive due process review by courts. ${ }^{120}$

It is an obvious enough response to current criticisms of the Court's federalism doctrine to say, "Well, it is not any worse than substantive due process." Part of our intention in this Article is to underscore that response: critics of the Rehnquist Court's new federalism cases have a serious obligation to explain why so many of them are willing to tolerate similar or even greater degrees of judicial adventurism in the area of substantive due process, despite nearly identical concerns about institutional competence. But Justice Souter's concurrence in Glucksberg is more important than that. Not only does it make clear that modern substantive due process doctrine shares virtually all of the important liabilities that nationalists tend to see in the Rehnquist Court's federalism cases, but it points the way toward how courts can overcome those liabilities in both contexts. Our essential point, then, is a positive one. By reaffirming both the responsibility of courts to work through difficult interpretive prob-

119. Larry Kramer, Understanding Federalism, 47 VAND. L. REV. 1485, 1499 (1994) [hereinafter Kramer, Understanding Federalism]; see also Jackson, supra note 5, at 2233 (suggesting a scrutiny of the relationship between Congress's means and its ends as an alternative to "enclave theory"); Rapaczynski, supra note 93, at 416 ("[I]t would be a mistake to think that cordoning off some areas of state governments from federal interference is the only possible method of implementing the principles of federalism."); Martin H. Redish, Doing It with Mirrors: New York v. United States and Constitutional Limitations on Federal Power to Require State Legislation, 21 HASTINGS CONST. L.Q. 593, 596-99 (1994) (arguing that limits on Congress's enumerated powers may be enforced without recourse to exclusive state enclaves).

120. In reality, of course, the Court has sanctioned a wide variety of different doctrinal approaches to substantive due process as well as personal privacy and autonomy. See, e.g., County of Sacramento v. Lewis, 523 U.S. 833, 845-46 (1998) (recognizing that substantive due process forbids "arbitrary" government action even outside the realm of fundamental rights, and that the nature of this protection varies depending on whether legislative or executive action is at issue); Washington v. Glucksberg, 521 U.S. 702, 765 (1997) (Souter, J., concurring) (arguing that the Due Process Clause protects a "continuum of rights to be free from 'arbitrary impositions and purposeless restraints" which take different forms in different contexts (quoting Poe v. Ullman, 367 U.S. 497, 543 (1961) (Harlan, J., dissenting))); Cruzan v. Dir., Mo. Dep’t of Health, 497 U.S. 261, 279 n.7 (1990) (preferring to analyze the right to refuse medical treatment as a Fourteenth Amendment liberty interest rather than as part of a general right to privacy); Eisenstadt v. Baird, 405 U.S. 438, 443 (1972) (striking down a state restriction on the sale of contraceptives using equal protection principles rather than identifying a fundamental right). 
lems and the efficacy of reasoned judgment and common law development in doing so, the Glucksberg concurrence goes a long way toward overcoming the competence objection to modern federalism doctrine. If federalism is to be placed on the "do not resuscitate" side of the double standard, it must be on grounds other than institutional competence.

\section{Is the Judiciary Competent to Develop Double Standards of Judicial Review?}

Our discussion so far has been consistent with the primary thrust of this Article, which takes the existence of a double standard as given and argues simply that federalism historically has been placed on the wrong side of it. Any discussion of double standards and judicial competence, however, cannot wholly avoid a more fundamental question: are judges competent to develop such a double standard in the first place? In our view, all of the difficulties involved in formulating workable substantive due process or federalism doctrine apply (in the worst way) to judicial attempts to articulate which constitutional principles should be enforced and which should not.

The problem arises because the Constitution does not come with "do not enforce" labels attached to some of its provisions. ${ }^{121}$ As one of the leading critics of judicially enforced federalism has acknowledged,

[there is] nothing in the language of the Constitution to distinguish questions of Congress's limits from any other question of constitutional law-no reason on the face of the text to treat questions regarding the reach of federal power differently from questions regarding the reach of state power or separation of powers or the Bill of Rights. ${ }^{122}$

121. The "textual commitment" prong of the political question doctrine suggests that the constitutional text sometimes will foreclose judicial enforcement. See, e.g., United States v. Nixon, 506 U.S. 224, 229-31 (1993) (finding that the text of Article I, Section 3, Clause 6, is a textual commitment to the Senate of sole power to try impeachments). One of us has argued elsewhere that the "textual commitment" test can never resolve a justiciability question without help from other factors. See Levinson \& Young, supra note 12 (manuscript at 71-95). Moreover, we think that the most persuasive account of the political question doctrine is that some constitutional provisions simply leave a lot of substantive discretion to political actors. See Louis Henkin, Is There a Political Question Doctrine?, 85 YALE L.J. 597, 662 (1976). We discuss the relevance of the political question doctrine further, infra notes 156-59 and accompanying text. See also Merritt, supra note 15, at 70-78 (arguing that even the Guarantee Clause in fact presents justiciable issues).

122. Kramer, Political Safeguards, supra note 16, at 234. 
In the absence of such guidance, confusion has reigned. As we demonstrated in Part I, the double standard was the law for nearly sixty years, and yet judges lack a settled definition or a well-accepted justification for it. This fact alone strongly suggests that judges should not attempt to declare certain parts of the Constitution "off limits" to judicial review.

The problem goes deeper than that, however. As we have suggested, the root concern about judicial competence in areas of legal indeterminacy is not that the judges will not be able to figure out how to rule in individual cases; rather, it is that they will not be able to articulate reasons of sufficient power to persuade observers that their decisions are principled. As Martha Field explains,

Whether the concept is one of state sovereignty or a right to contract, judges applying it in the absence of clear guidelines must resort to their own opinions concerning the worth of social and economic legislation-an area in which they do not possess superior knowledge or institutional competence. Thus, the Court becomes vulnerable to a charge that it is acting as a superlegislature. ${ }^{123}$

Justice Souter made just such a charge in Morrison, arguing that "The Court's thinking betokens ... a return ... to something like the unsteady state of obscenity law ... in which the failure to provide a workable definition left this Court to review each case ad hoc." ${ }^{124}$ This kind of "ad hoc review," he argued, "cannot preserve the distinction between the judicial and the legislative, and this Court, in any event, lacks the institutional capacity to maintain such a regime for very long.,"125

Although Professor Field and Justice Souter level their charge at the Court's federalism jurisprudence, it is hard to see why it does not apply equally well to the open-ended individual rights jurisprudence they have embraced in other contexts. ${ }^{126}$ Institutional competence, in other words, cannot provide a determinate principle of inclusion and exclusion that guides the courts in deciding what parts of the Consti-

123. Field, supra note 88, at 94-95.

124. United States v. Morrison, 529 U.S. 598, 654-55 (2000) (Souter, J., dissenting) (citing Redrup v. New York, 386 U.S. 767 (1967), and Miller v. California, 413 U.S. 15 (1973)).

125. Id. at 656; see also Nat'l League of Cities v. Usery, 426 U.S. 833, 868 (1976) (Brennan, J., dissenting) (pointing out that similar attempts to create a restrictive construction of the commerce power led to a constitutional crisis in the 1930s).

126. See, e.g., Martha A. Field, Abortion and the First Amendment, 29 U.C. DAVIS L. REV. 545,550 (1996) (embracing broad protection for "the right to choose how to be or the right to develop one's own personality" under the First Amendment). 
tution to enforce. ${ }^{127}$ Absent such a principle, the Court's double standard itself raises the same sort of concerns highlighted by Justice Souter and Professor Field. Without a principled basis for enforcing some constitutional principles but not others, the Court becomes vulnerable to the charge that it chooses "favored" principles based on the personal ideological, moral, or policy commitments of the Justices. One might say, in other words, that the Court has become not a "superlegislature," but a super-Constitutional Convention.

The inference that the Justices are pursuing their own preferences becomes all the more compelling when one takes the likely institutional biases of the Justices into account. As Steven Calabresi points out, "the Justices and judges of the U.S. federal courts are national officers in every possible sense of that term." ${ }^{128}$ It is thus not surprising that "the Supreme Court's past record is one of ferocious scrutiny of state laws and general deference to national ones." ${ }^{129}$ Professor Calabresi thus argues-convincingly, in our view-that we are far more likely to see underenforcement of states' rights from the federal courts than overly aggressive judicial review. ${ }^{130}$ We do not see invalidation of two largely symbolic laws under the Commerce Clause $^{131}$ (or two obscure ones under the anticommandeering doctrine $)^{132}$ as significant evidence to the contrary. ${ }^{133}$

127. Nor, as we show in the next Part, can arguments about the "necessity" of judicial review be based on the existence of "political safeguards" for some constitutional values. See infra Part III.

128. Steven G. Calabresi, “A Government of Limited and Enumerated Powers": In Defense of United States v. Lopez, 94 MiCH. L. REV. 752, 808 (1995).

129. Id.

130. Id. at $806-11$.

131. See infra notes $187-89$ and accompanying text (discussing the essentially symbolic significance of the Gun-Free School Zones Act invalidated in Lopez); United States v. Morrison, 529 U.S. 598, 636 n.10 (Souter, J., dissenting) (questioning the practical need to federalize traditional state crimes).

132. See Printz v. United States, 521 U.S. 898, 902-04 (1997) (noting that the Brady Act provisions at issue required commandeering of state officials only as an interim measure before the federal background-check mechanism created by the Act went into effect); New York v. United States, 505 U.S. 144, 189-94 (1992) (White, J., concurring in part and dissenting in part) (observing that the case involved an interstate compact scheme that had been negotiated among the states with Congress acting as a referee).

133. The consistent string of invalidations under the Court's state sovereign immunity doctrine might be a better counterexample. See, e.g., Bd. of Trs. of the Univ. of Ala. v. Garrett, 531 U.S. 356, 121 S. Ct. 955, 967-68 (2001) (holding that Title I of the Americans with Disabilities Act did not validly abrogate state sovereign immunity pursuant to Section Five of the Fourteenth Amendment); Fla. Prepaid Postsecondary Educ. Expense Bd. v. Coll. Sav. Bank, 527 U.S. 627, 630 (1999) (holding the same for the Patent Act); Seminole Tribe v. Florida, 517 U.S. 44, 72-73 (1996) (holding that Congress may not abrogate state sovereign immunity when it acts 
Concerns about the legitimacy of selective constitutional enforcement have sharply limited the Court's willingness to declare particular issues nonjusticiable. As Chief Justice Marshall observed long ago, "[w]e have no more right to decline the exercise of jurisdiction which is given, than to usurp that which is not given. The one or the other would be treason to the constitution." 134 The power of judicial review, moreover, arises directly out of this obligation to decide the cases that arise within the Court's jurisdiction. ${ }^{135}$ This obligation is no doubt why Professor Wechsler, despite arguing against the need for extensive judicial review of federalism issues, was careful to add that "[t]his is not to say that the Court can decline to measure national enactments by the Constitution when it is called upon to face the question in the course of ordinary litigation; the supremacy clause governs there as well." ${ }^{136}$ And it is why Professor Van Alstyne properly views the Court's abdication of this responsibility in Garcia as a "piecemeal repeal of judicial review." 137

To be sure, the political question doctrine has long stood for the proposition that some constitutional issues are nonjusticiable despite

pursuant to its Article I powers). It is critical to remember, however, that the Court has not invalidated the regulatory provisions of the federal statutes at issue in these cases. The states remain bound by the Americans with Disabilities Act, the Patent Act, and the like. Rather, they simply cannot be sued by private individuals for money damages without their consent. The states still may be held accountable for violations of these and other federal laws through suits by the United States, suits against state officers for injunctive relief (or for damages relief if the officer is sued in his personal capacity), or conditional federal spending schemes designed to induce the states to waive their immunity. See e.g., Mitchell N. Berman, R. Anthony Reese \& Ernest A. Young, State Accountability for Violations of Intellectual Property Rights: How to "Fix" Florida Prepaid (And How Not To), 79 TEX. L. REV. 1037, 1045-51 (2001). While we would not go so far as to agree with John Jeffries that "[t]he Eleventh Amendment almost never matters," John C. Jeffries, Jr., In Praise of the Eleventh Amendment and Section 1983, 84 VA. L. REV. 47, 49 (1998), we do not view the sovereign immunity cases as evidence that the Court intends to radically shift the balance of governmental power in favor of the states.

134. Cohens v. Virginia, 19 U.S. (6 Wheat.) 264, 404 (1821).

135. See, e.g., BICKEL, supra note 47, at 114 (interpreting Marbury to hold that "the judiciary's power to construe and enforce the Constitution ... is to be deduced from the obligation of the courts to decide cases conformably to law"); Herbert Wechsler, The Courts and the Constitution, 65 COLUM. L. REV. 1001, 1006 (1965):

Federal courts, including the Supreme Court, do not pass on constitutional questions because there is a special function vested in them to enforce the Constitution or police the other agencies of government. They do so rather for the reason that they must decide a litigated issue that is otherwise within their jurisdiction and in doing so must give effect to the supreme law of the land.

136. Wechsler, supra note 16, at 559.

137. Van Alstyne, supra note 4, at 1724. 
the fact that they fall within the jurisdiction of the federal courts. ${ }^{138}$ That doctrine indeed rests at least partly on the same kinds of concerns about judicial competence that we have been discussing; an issue may be nonjusticiable if a court finds "'a lack of judicially discoverable and manageable standards for resolving it." ${ }^{\prime 139}$ And yet, we see virtually no one arguing that federalism issues are nonjusticiable within the meaning of the political question doctrine. ${ }^{140}$ In fact, people of widely differing views on the merits of the federalism cases have been able to agree that the cases must be decided by courts on the merits. ${ }^{141}$

We do not see political question arguments in federalism cases because the set of nonjusticiable issues under the political question doctrine is widely acknowledged to be very small. It has to be: if one were to take seriously the idea that judges should not decide constitutional issues in the absence of readily manageable standards, one

138. E.g., Nixon v. United States, 506 U.S. 224, 228 (1993); Baker v. Carr, 369 U.S. 186, 210 26 (1962); Marbury v. Madison, 5 U.S. (1 Cranch) 137, 170 (1803).

139. Nixon, 506 U.S. at 228 (quoting Baker, 369 U.S. at 217). The Court offered a more comprehensive list of factors in Baker. 369 U.S. at 217. Justice Brennan wrote there that nonjusticiable cases tend to involve

a textually demonstrable constitutional commitment of the issue to a coordinate political department; or a lack of judicially discoverable and manageable standards for resolving it; or the impossibility of deciding without an initial policy determination of a kind clearly for nonjudicial discretion; or the impossibility of a court's undertaking independent resolution without expressing lack of the respect due coordinate branches of government; or an unusual need for unquestioning adherence to a political decision already made; or the potentiality of embarrassment from multifarious pronouncements by various departments on one question.

$I d$. at 217. Subsequent cases, however, have focused almost exclusively on the "textual commitment" and "manageable standards" prongs of the doctrine. See, e.g., Nixon, 506 U.S. at 228-33; Levinson \& Young, supra note 12 (manuscript at 86-90). We discuss the textual commitment aspect of nonjusticiability infra notes 157-59 and accompanying text.

140. See, e.g., Yoo, supra note 87, at 1332:

It is puzzling that the Garcia majority did not resort to the political question doctrine .... [T] he majority had only discussed the difficulty of articulating standards to indicate that there was a deeper difficulty with judicial review in this area. It had avoided the implication that the lack of articulable standards constituted sufficient grounds for eliminating judicial review ....

Dean Choper does argue that federalism issues should be "nonjusticiable," CHOPER, supra note 28 , at 193, but he does not attempt to fit his "federalism proposal" into the requirements of the political question doctrine.

141. See, e.g., Levinson \& Young, supra note 12 (manuscript at $56 \mathrm{n} .90$ ); see also supra notes 104-07 and accompanying text (discussing the inevitable need for "reasoned judgment" in most areas of constitutional law). 
would end up throwing out most of constitutional law. ${ }^{142}$ What is puzzling, however, is why we still hear judicial competence arguments against any judicial review of federalism issues even after it is conceded that the political question doctrine does not apply. Whether or not it is possible to identify a small set of constitutional issues that are so indeterminate that judges ought not be empowered to decide them, surely we should not allow further discretion to enforce or not enforce outside that narrow realm. The political question doctrine, in other words, ought to exhaust the category of constitutional principles that the judiciary may refuse to enforce.

To say that the judiciary may not decline to enforce federalism constraints on competence grounds is not, of course, to determine the appropriate rigor of judicial review. In any number of instances, courts have articulated deferential standards of review in response to concerns about the relative institutional competence of courts vis-àvis the political branches. ${ }^{143}$ But this problem of doctrinal design recurs throughout constitutional law, and the relevant considerationswhich surely include the necessity of judicial enforcement and the normative appeal of the relevant values, as well as the issue of judicial competence-may play out differently in different situations even within the same general doctrinal context. ${ }^{144}$ We cannot address here

142. See Levinson \& Young, supra note 12 (manuscript at 87) (“[The 'judicially manageable standards' criterion] simply can't mean that the Court should abstain on justiciability grounds in any or all areas in which it has arguably done a poor job of doctrinal elaboration.").

143. See, e.g., McCleskey v. Kemp, 481 U.S. 279, 319 (1987) (deferring to the superior institutional competence of legislatures to prescribe rules for capital sentencing); Lawrence Gene Sager, Fair Measure: The Legal Status of Underenforced Constitutional Norms, 91 HARV. L. REV. 1212, 1226 (1978) (discussing the unwillingness of courts to fully enforce some constitutional norms due to concerns about "institutional inappropriate[ness]"). Once again, Justice Souter may have said it best:

I take it that the basic concept of judicial review with its possible displacement of legislative judgment bars any finding that a legislature has acted arbitrarily when the following conditions are met: there is a serious factual controversy over the feasibility of recognizing the claimed right without at the same time making it impossible for the State to engage in an undoubtedly legitimate exercise of power; facts necessary to resolve the controversy are not readily ascertainable through the judicial process; but they are more readily subject to discovery through legislative factfinding and experimentation.

Washington v. Glucksberg, 521 U.S. 702, 786-87 (1997) (Souter, J., concurring).

144. Hence, for example, we have three different tiers of scrutiny within equal protection doctrine. See, e.g., City of Cleburne v. Cleburne Living Ctr., Inc., 473 U.S. 432, 439-41 (1985) (discussing rational basis review, heightened scrutiny, and strict scrutiny). Moreover, in many areas, even the most deferential tier of scrutiny has sufficient "bite" to occasionally require striking down a law. See, e.g., Romer v. Evans, 517 U.S. 620, 635 (1996) (declaring unconstitutional a state constitutional amendment that appeared motivated by animus towards homosexuals rather than by the desire to serve a legitimate governmental purpose); City of Cleburne, 473 
the broader question of how federalism doctrine should be designed. Our narrow point, rather, is that judicial competence concerns cannot justify a categorical distinction between federalism and other constitutional principles.

\section{THE NECESSITY PROBLEM}

Even if judges face roughly equivalent difficulties in developing and enforcing federalism and substantive due process, one still might argue that the burden of judicial review should be shouldered only where it is absolutely necessary - that is, where no alternative institutional safeguard exists to protect the constitutional value in question. This argument raises the second of the justifications for the double standard that we discussed previously: the claim that judicial review is necessary only in the category of "preferred rights," because "political safeguards" protect the remaining values without judicial intervention. ${ }^{145}$

This claim long has been the centerpiece of the antifederalism position, both on the Court ${ }^{146}$ and in the academy. ${ }^{147}$ Despite its familiarity, however, the political safeguards argument involves some crucial ambiguities. We thus begin in Section A of this Part with an attempt to clarify the nature of the argument and the concerns that political safeguards ought to guard against. Section B discusses one set of concerns, involving the aggrandizement of national power at the expense of all the states. In Section C, we turn to a second-and frequently overlooked-set of concerns regarding the use of the national government as a tool by which some states aggrandize themselves at the expense of others. The inadequacy of political safeguards in guarding against both these "vertical" and "horizontal" concerns,

U.S. at 450 (invalidating the city's special-use permit requirement because it was based on irrational prejudice).

145. See, e.g., Yoo, supra note 87, at 1333 ("Refusing to employ judicial review in the federalism area inverts the Carolene Products approach. If judicial review is necessary when the political process fails to protect a group, then judicial intervention should be equally unnecessary when a group - here, the states - is adequately represented in the governmental system.").

146. E.g., United States v. Morrison, 529 U.S. 598, 649-50 (2000) (Souter, J., dissenting); Kimel v. Fla. Bd. of Regents, 528 U.S. 62, $93-95$ (2000) (Stevens, J., dissenting); Garcia v. San Antonio Metro. Transit Auth., 469 U.S. 528, 550-51 (1985).

147. See, e.g., CHOPER, supra note 28, at 175-84 (proposing that "the constitutional issue of whether federal action is beyond the authority of the central government and thus violates 'states' rights' should be treated as nonjusticiable, final resolution being relegated to the political branches"); Kramer, Political Safeguards, supra note 16, at 278-87; D. Bruce La Pierre, The Political Safeguards of Federalism Redux: Intergovernmental Immunity and the States as Agents of the Nation, 60 WASH. U. L.Q. 779, 789 (1982); Wechsler, supra note 16, at 559. 
respectively, leads us to reject necessity as a justification for the double standard. Finally, in Section D, we demonstrate that a necessity rationale cannot explain the cases-that is, that the political safeguards argument is available in any number of areas where judicial review is well accepted.

\section{A. What Are "Political Safeguards," and What Are They Guarding Against?}

Although the Garcia Court justified its retreat from judicial enforcement of federalism partly in terms of judicial competence, it relied more fundamentally on the view that "the principal means chosen by the Framers to ensure the role of the States in the federal system lies in the structure of the Federal Government itself."148 Justice Blackmun went on to observe that

The Framers thus gave the States a role in the selection both of the Executive and the Legislative Branches of the Federal Government. The States were vested with indirect influence over the House of Representatives and the Presidency by their control of electoral qualifications and their role in Presidential Elections. ... They were given more direct influence in the Senate, where each State received equal representation and each Senator was to be selected by the legislature of his State. ${ }^{149}$

The existence of these safeguards led the majority to conclude that "[s]tate sovereign interests ... . are more properly protected by procedural safeguards inherent in the structure of the federal system than by judicially created limitations on federal power."150

In its reasoning, the Garcia majority echoed that of Professor Herbert Wechsler, whom it cited. ${ }^{151}$ In his now-classic 1954 article, Wechsler observes that the Senate, in which all states are equally represented, "cannot fail to function as the guardian of state interests as such," and that "[f]ederalist considerations ... play an important part even in the selection of the President." ${ }^{, 152}$ He therefore concluded that

\footnotetext{
148. Garcia, 469 U.S. at 550.

149. Id. at 551.

150. Id. at 552 .

151. Id. at $551 \mathrm{n} .11$. The Court also cited CHOPER, supra note 28, and La Pierre, supra note 147.

152. Wechsler, supra note 16 , at 548,557 . The article ranked as the sixty-ninth most-cited article since 1956 in a citation count published in 1996, and the current Court's federalist revival has surely caused the article's ranking to improve during the intervening five years. See Fred R. Shapiro, The Most-Cited Law Review Articles Revisited, 71 CHI.-KENT L. REV. 751, 770 (1996).
} 
"the Court is on weakest ground when it opposes its interpretation of the Constitution to that of Congress in the interests of the states, whose representatives control the legislative process and, by hypothesis, have broadly acquiesced in sanctioning the challenged Act of Congress." 153

Although the Garcia majority was willing to admit that "changes in the structure of the Federal Government... since 1789 ... may work to alter the influence of the States in the federal political process, ${ }^{, 154}$ it concluded that the political safeguards remained largely effectual. The Court cited, for example, federal legislation providing increasingly large financial grants to states and localities, as well as Congress's frequent willingness to exempt states and their political subdivisions from generally applicable regulatory regimes ranging from the Employee Retirement Income Security Act (ERISA) to the Federal Power Act. ${ }^{15}$

It is important to be clear about what this political safeguards argument does and does not entail. We already have discussed why the difficulty of establishing workable doctrine in the federalism area should not be-and generally is not argued to be-sufficient to make federalism issues nonjusticiable under the political question doctrine. ${ }^{156}$ One might accept our argument, however, and still employ Professor Wechsler's analysis to invoke that doctrine under its "textual commitment" prong. One might claim, in other words, that the constitutional provisions establishing structural safeguards for state autonomy represent "a textually demonstrable constitutional commitment of the issue to a coordinate political department." ${ }^{157}$ But just as critics of federalism review generally have not argued that workable standards are so elusive in this area as to render the issues nonjusticiable, so, too, even those critics who believe federalism should be nonjusticiable have eschewed the idea of textual commitment. Dean Choper, for example, acknowledges that "[t]he clauses of the Constitution that allocate power between the national government

153. Wechsler, supra note 16, at 559 (footnote omitted); see also id. at 558 ("Far from a national authority that is expansionist by nature, the inherent tendency in our system is precisely the reverse ....").

154. Garcia, 469 U.S. at 554. The Court cited "the substitution of popular election of Senators by the adoption of the Seventeenth Amendment in 1913" as the most important example. Id.

155. Id. at 552-53.

156. See supra notes $138-42$ and accompanying text.

157. Baker v. Carr, 369 U.S. 186, 217 (1962). For some problems with the "textual commitment" prong, see supra note 121. 
and the states," like the Guarantee Clause or the amendment procedures in Article V, "no more obviously concern matters 'committed by the Constitution to another branch of government' than do most other clauses of the Constitution that have been traditionally subject to judicial interpretation." ${ }^{158}$ Instead, Dean Choper makes clear, his argument for a double standard of justiciability is grounded firmly in "functional considerations" concerning the necessity of judicial review. ${ }^{159}$

The political safeguards claim, in other words, rests on prudential considerations rather than on constitutional command: we do not need judicial review of federalism issues because the political structure alone will keep the states safe. But safe from what? Here, it will help to distinguish between two different potential threats to state autonomy that often are conflated in the federalism debate. One sort of threat, which we term "vertical" aggrandizement, involves efforts by the federal government to increase its own power at the expense of the states. Such aggrandizement may occur, for example, when the federal government takes over regulatory functions traditionally exercised by the states, ${ }^{160}$ preempts sources of state revenue, ${ }^{161}$ or imposes regulatory burdens on state governments. ${ }^{162}$ The substantive preferences of the states in these situations are irrelevant to the issue of vertical encroachment. The states may be relatively united in opposing the federal initiative on the merits $;{ }^{163}$ they actually may favor the federal initiative or have adopted similar policies on their own; ${ }^{164}$ or different states may have different preferences altogether. The de-

\footnotetext{
158. CHOPER, supra note 28, at 405-06.

159. Id. at 406.

160. See, e.g., AT\&T Corp. v. Iowa Utils. Bd., 525 U.S. 366, 397 (1999) (holding that Congress gave the Federal Communications Commission the authority to implement and interpret the Telecommunications Act of 1996, thereby displacing state regulatory authority over local telephone services).

161. See, e.g., Lynn A. Baker, Conditional Federal Spending After Lopez, 95 Colum. L. REV. 1911, 1935-39 (1995) [hereinafter Baker, Conditional Federal Spending]. See generally Baker, Spending Power, supra note 15.

162. See, e.g., Garcia v. San Antonio Metro. Transit Auth., 469 U.S. 528, 555-56 (1985) (holding that Congress could validly subject state employees to the Fair Labor Standards Act); Nat'l League of Cities v. Usery, 426 U.S. 833, 833 (1976) (rejecting the application of the FLSA to state employees involved in "traditional governmental functions").

163. All fifty states, for example, generally (although not always) would have the same incentives to oppose burdensome regulation of their own governmental operations by federal laws like the FLSA.

164. See, e.g., United States v. Lopez, 514 U.S. 549, 581 (1995) (Kennedy, J., concurring) (noting that more than forty states already had gun-free school laws on their books at the time
} the Court ruled). 
fining characteristic is that the impetus for the expansion of federal power comes from the federal government or from interest groups operating at the federal level, and not from state governmental institutions or geographically based interests primarily concentrated at the state level.

We term the second kind of threat to state autonomy "horizontal" aggrandizement, because its focus is on the differences among the states in their substantive policy preferences. Here the federal political process threatens state autonomy insofar as that process is the means by which a majority of states may impose their own policy preferences on a minority of states with different preferences. The federal political process therefore in certain circumstances may threaten the autonomy of only some states, while arguably enhancing the autonomy of other states. An example might be efforts by interests concentrated in more socially conservative parts of the country to formulate and enact a uniform definition of "marriage" at the federal level to undermine attempts in more liberal states to legalize gay unions. ${ }^{165}$ This sort of horizontal problem typically is overlooked in contemporary debates about federalism, ${ }^{166}$ but we think it raises a distinct and potentially more serious criticism of the efficacy of political safeguards than traditional critiques focusing exclusively on vertical issues. ${ }^{167}$

Just as the Garcia majority articulated the definitive necessity argument for placing federalism on the "do not enforce" side of 1937's double standard, Justice Powell's dissent in the same case identified

165. See Kristian D. Whitten, Section Three of the Defense of Marriage Act: Is Marriage Reserved to the States?, 26 HASTINGS CONST. L.Q. 419, 440 (1999) (discussing the origin of the Defense of Marriage Act, Pub. L. No. 104-199, 110 Stat. 2419 (1996) (codified at 28 U.S.C. § 1738C and 1 U.S.C. $\$ 7$ (Supp. V 1999)), as "a Congressional response to the opinion of two members of the five judge Hawaii Supreme Court who suggested that Hawaii's State constitution requires the recognition of same sex marriages").

166. A rare exception is Baker, Conditional Federal Spending, supra note 161, at 1940 (demonstrating that conditional federal spending unfettered by the Constitution's constraints is problematic because it allows "some states to harness the federal lawmaking power to oppress other states").

167. We should note that although we find it useful and informative to distinguish between vertical and horizontal federalism issues, the two categories obviously are not discrete, nor do we intend them to have any particular doctrinal import. Thus, reasonable people sometimes may disagree about whether a particular issue is ultimately or primarily a vertical or horizontal one. To our minds, a major benefit of emphasizing this distinction is to emphasize for liberals the "diversity" benefits that accrue from the judicial enforcement of state autonomy. See generally Lynn A. Baker, Should Liberals Fear Federalism?, 70 U. CIN. L. REV. (forthcoming Jan. 2002) (manuscript on file with the Duke Law Journal). 
two crucial problems with this position. ${ }^{168}$ First, Justice Powell questioned the efficacy of any political safeguards for federalism. Nothing in the Court's opinion, he pointed out, "explain[ed] how the States' role in the [federal] electoral process guarantees that particular exercises of the Commerce Clause power will not infringe on residual state sovereignty." ${ }^{169}$ Second, Justice Powell argued that the existence of political checks in the federalism context failed to distinguish federalism from other constitutional values-individual rights ${ }^{170}$ and separation of powers ${ }^{171}$ - that the Court had proven willing and able to enforce. The necessity problem, in other words, failed to distinguish federalism from "preferred rights" and other principles on the favored side of the double standard.

Our analysis in the Sections that follow basically tracks the argument of Justice Powell's dissent. We first ask whether political safeguards are sufficiently effective to obviate the need for judicial review, dividing our analysis between vertical and horizontal issues in Sections B and C, respectively. We conclude that although political safeguards undoubtedly protect the states from some vertical threats, they are insufficiently reliable to operate without a robust role for judicial review; moreover, political safeguards do nothing to address the horizontal problem of federal "homogenization" of diverse state policy preferences, which imposes burdens on some states to the benefit of other states. Finally, Section D addresses Justice Powell's second point: that the Court has not hesitated to engage in searching judicial review in other areas—such as individual rights and separation of

168. Justice Powell was joined by Chief Justice Burger as well as by Justices Rehnquist and O'Connor. The latter two Justices also filed vigorous dissents that foreshadowed the present "federalist revival." Garcia, 469 U.S. at 580 (Rehnquist, J., dissenting) (asserting that the principle of federalism set out in National League of Cities "will, I am confident, in time again command the support of a majority of this Court"); id. at 589 (O'Connor, J., dissenting) ("I would not shirk the duty acknowledged by National League of Cities and its progeny, and I share Justice Rehnquist's belief that this Court will in time again assume its constitutional responsibility.").

169. Id. at 564 (Powell, J., dissenting).

170. Id. at 565 n.8:

One can hardly imagine this Court saying that because Congress is composed of individuals, individual rights guaranteed by the Bill of Rights are amply protected by the political process. Yet, the position adopted [by the majority] today is indistinguishable in principle. The Tenth Amendment also is an essential part of the Bill of Rights.

171. Id. at 567 n.12 (discussing Buckley v. Valeo, 424 U.S. 1 (1976), and Meyers v. United States, 272 U.S. 52 (1976), and further observing that "[t]his Court has never before abdicated responsibility for assessing the constitutionality of challenged action on the ground that affected parties theoretically are able to look out for their own interests through the electoral process"). 
powers-where equally plausible political safeguards arguments can be made.

\section{B. States Versus Nation: The Problem of Vertical Aggrandizement}

Neither Professor Wechsler nor the Garcia majority distinguished between vertical and horizontal aspects of state sovereignty. Nonetheless, the focus of the discussion of each appears to have been the problem of vertical aggrandizement: that is, attempts by the federal government to expand its own power at the expense of the states as a whole. Such aggrandizement might be the result either of federal officials seeking to increase their own power at the expense of the states, ${ }^{172}$ or of successful lobbying by private interest groups whose influence is concentrated at the national level. ${ }^{173}$ The situation in Garcia is a good example of such vertical aggrandizement. Congress's extension of the Fair Labor Standards Act's wage and hour requirements to state governmental employers was an attempt by the federal government to impose regulatory burdens on state governmental institutions, thereby presumably expanding its own power at the expense of the states as a whole. ${ }^{174}$ And Professor Wechsler's analysis, on which the Garcia majority relied, tends to treat the states as a group with a single shared set of interests and a common enemy, without examining the role that federal lawmaking institutions might play in contests among states with different preferences on particular issues.

The most obvious problem with the political safeguards Professor Wechsler and the Garcia majority describe-even if we confine ourselves for the moment to the vertical problem-is that practically no one really seems to believe in them anymore. ${ }^{175}$ Even Professor

172. See Bednar \& Eskridge, supra note 105, at 1473-74 (describing Congress's incentives to "cheat" on the federal arrangement by aggrandizing its own power at the expense of the states).

173. See Rapaczynski, supra note 93, at 388 (arguing that the federal government is likely to be influenced by well-established interest groups that have incentives to suppress the more diverse interests likely to be prevalent in the states).

174. One can imagine something like the Fair Labor Standards Act being enacted as a response to horizontal pressures. For instance, states with relatively high prevailing wages might worry about losing businesses to lower wage states and therefore seek to impose minimum wages at the national level. Whether something like this motivation lay behind the original enactment of the FLSA to govern private employers, it strikes us as a more far-fetched explanation for Congress's subsequent decision to extend the FLSA to public employers. Finally, for present purposes, it does not matter whether the congressional action was the result of a raw "power grab" by federal legislators or successful lobbying by a powerful private interest group.

175. See Bednar \& Eskridge, supra note 105, at 1484-85 ("Garcia has, justifiably, taken an academic beating for arguing that the formal representation of the states in the Senate and the Electoral College and their ostensible control over House redistricting assure that states qua states will be adequately protected by the ordinary political process.”). 
Kramer, who believes that the political safeguards argument can be saved through re-tooling, concedes that "however convincing Wechsler's reasoning may have been in its original context, subsequent experience and later developments have robbed his analysis of much, if not all, of its force." ${ }^{, 176}$ The reasons this belief is outdated have been discussed at length elsewhere, ${ }^{177}$ and we recount them only briefly here.

The first vertical safeguard Wechsler identifies is a national "mood," under which national action is "regarded as exceptional in our polity, an intrusion to be justified by some necessity, the special rather than the ordinary case." place the "burden of persuasion on those favoring national intervention," so that federal law would remain "a largely interstitial product" with the balance of regulatory activity remaining with the states. ${ }^{179}$ This view, however, is widely conceded to be outdated. ${ }^{180}$ Moreover, as Professor Kramer observes, "The existence of the tradition Wechsler described is the fact to be explained, and cannot itself provide a source of solace to those concerned about unchecked federal growth." 181

When we turn from "mood" to government structure, Professor Wechsler's safeguards fare no better. His primary structural safeguards, the state-by-state allocation of electoral votes and congressional representation, do little to protect the interests of state governments as institutions from federal usurpation and encroachment. ${ }^{182}$

176. Kramer, Political Safeguards, supra note 16, at 218.

177. Id. at 220-27; Prakash \& Yoo, supra note 16, at 1471-80.

178. Wechsler, supra note 16, at 544.

179. Id. at 545.

180. See, e.g., Kramer, Understanding Federalism, supra note 119, at 1506 ("[A]ny presumption in favor of state law for its own sake had begun to lose its strength by the mid-nineteenth century, and developments in this century have merely been a continuation (and acceleration) of this process."). But see Kramer, Political Safeguards, supra note 16, at 220 (suggesting that Congress still "hesitates before displacing state law"). Perhaps the most telling example is that Professor Wechsler's parallel assertion that "[f]ederal law is generally interstitial in its nature" in his celebrated casebook, Henry M. HART, JR. \& Herbert WechSLER, The Federal COURTS AND THE FEDERAL SYSTEM 435 (1st ed. 1953), has been reproduced in the 1996 edition alongside an acknowledgement that "today federal law appears to be more primary than interstitial in numerous areas," RICHARD H. FALLON ET AL., HART AND WECHSLER'S THE FEDERAL COURTS AND THE FEDERAL SYSTEM 521-22 (4th ed. 1996).

181. Kramer, Political Safeguards, supra note 16, at 221.

182. Jackson, supra note 5, at $2226 \mathrm{n} .206$ (noting that "senators, like their colleagues in the House, are said to represent, not the interests of states as governments, but the interests of people in the states"); Kramer, Political Safeguards, supra note 16, at 223 (noting that most of Wechsler's structural safeguards "are mechanisms that (possibly) give state and local interests a 
The only constitutional institution that did promote the representation of state institutional interests, the selection of senators by state legislatures, is now gone. ${ }^{183}$ Today, if federal representatives (including the president as well as members of Congress) are responsive to state and local interests, those federal representatives may become competitors of the state and local politicians who represent the same constituents. ${ }^{184}$ According to the "economic theory of regulation," politicians obtain political support from constituents in exchange for providing beneficial regulation and government services. ${ }^{185}$ The implication is that political support tracks governmental authority, and any official seeking to maximize his own support would seek to maximize his own regulatory jurisdiction at the expense of other public officials seeking support from the same constituents. ${ }^{186}$

The Gun-Free School Zones Act struck down in Lopez seems like a clear example. At the time Congress passed this law, more than forty states already had enacted prohibitions on the possession of guns in or near schools, and there was no evidence that these state laws were ineffective. ${ }^{187}$ Nor was there any evidence that the few states that had not yet enacted such a prohibition opposed the social policy involved. Thus, an entirely plausible explanation for the federal legislation is that members of Congress were seeking a share of

greater voice in national politics, but in ways that do not necessarily protect state and local institutions").

183. U.S. CONST. amend. XVII.

184. Merritt, supra note 15, at 15-16; Young, State Sovereign Immunity, supra note 114, at 26.

185. Jonathan R. Macey, Federal Deference to Local Regulators and the Economic Theory of Regulation: Toward a Public-Choice Explanation of Federalism, 76 VA. L. REV. 265, 269 (1990); see also Baker, Conditional Federal Spending, supra note 161, at 1940-47; Baker, Spending Power, supra note 15, at 200-02, 222-25.

186. Clayton P. Gillette, The Exercise of Trumps by Decentralized Governments, 83 VA. L. REV. 1347, 1357 (1997) (observing that "[w]here central representatives are popularly elected, they may have a stake in reelection that induces them to favor central intervention whenever they can thereby be perceived as addressing an issue of interest to constituents, regardless of whether centralized attention to the issue is required or authorized"); Young, State Sovereign Immunity, supra note 114, at 46. This would be especially true if we assume that the pool of "support"-especially campaign contributions-is finite within any given group of constituents. A wealthy businesswoman with important regulatory interests, for instance, might well decide whether to concentrate her campaign contributions during a given election cycle to candidates at the state or federal level, depending on which level of government she perceived as having primary authority to influence her interests.

187. United States v. Lopez, 514 U.S. 549, 581 (Kennedy, J., concurring) (citing state statutes regulating possession of guns in school zones); see also Todd S. Purdum, Clinton Seeks Way to Retain Gun Ban in School Zones, N.Y. TIMES, Apr. 30, 1995, at A1 (suggesting that, because many states already had laws banning guns in or near schools, the federal statute was largely symbolic). 
the credit for addressing this (uncontroversial) issue. ${ }^{188}$ In the words of one commentator: "[T]he Gun-Free School Zones Act was little more than a press release from Congress that it cared."

Acknowledging the inefficacy of traditional structures like state "representation" in Congress and the electoral college as vertical safeguards, Professor Wechsler's intellectual heirs have sought to identify alternative safeguards to take their place. Larry Kramer thus contends that "federalism in the United States has been safeguarded by a complex system of informal political institutions (of which political parties have historically been the most important)." ${ }^{, 190}$ According to Professor Kramer, political parties "protect[] the states by making national officials politically dependent upon state and local party organizations.",191

This may be true, at least to some extent. But Kramer's argument suffers from what seems to us a fairly substantial flaw: ${ }^{192}$ unlike the institutional safeguards upon which Wechsler relies, political parties are not part of the constitutional structure. The nature of the party system and its role in protecting federalism are thus necessarily fluid and contingent. In the past, changes in party organization-for example, the adoption of presidential primaries in most states and the corresponding de-emphasis of the nominating convention-have had massive and unanticipated effects on the structure and nature of our po-

188. See Kramer, Understanding Federalism, supra note 119, at 1510-11:

Federal politicians will want to earn the support and affection of local constituents by providing desired services themselves_-through the federal government-rather than to give or share credit with state officials. State officials are rivals, not allies, a fact the Framers understood and the reason they made Senators directly beholden to state legislators in the first place.

One of us has suggested previously that the passage of the federal Gun-Free School Zones Act might be considered an example of what we now categorize as a horizontal aggrandizement. Baker, Conditional Federal Spending, supra note 161, at 1941-44. Given the strong likelihood that the content of this regulation was normatively uncontroversial even in the few states that had not yet enacted a similar law, however, the enactment of this federal law seems (to both of us) more plausibly to be categorized as an example of the failures of existing vertical safeguards.

189. Jerome L. Wilson, High Court Did Well in School-Guns Case, N.Y. TIMES, May 5, 1995, at A30; see also United States v. Morrow, 834 F. Supp. 364, 366 (N.D. Ala. 1993) ("A generalized salutary purpose is simply not enough to justify the creation of a new federal crime. Liking the way 'Gun-Free School Zones' rolls off the tongue does not make $\$ 922(q)$ constitutional.").

190. Kramer, Political Safeguards, supra note 16, at 219.

191. Id. at 278.

192. For more extensive discussion of other arguable flaws in Kramer's argument, see Baker, Safeguards, supra note 16; Prakash \& Yoo, supra note 16, at 1480-89. 
litical parties. ${ }^{193}$ Alteration of the ways election campaigns are financed likewise might alter the nature and role of the parties. ${ }^{194}$ To abdicate judicial enforcement of the Constitution's federalism principles in favor of a mechanism as shifting and unstable as political parties would be to undermine the very idea of constitutionalism..$^{195}$

Stabilizing the political party system sufficiently to make it a reliable safeguard for constitutional values of federalism would require entrenching a particular conception of the party system through some form of judicial review. But this, it seems to us, would give the game away entirely. It would be to trade one form of judicial review which, though controversial, at least has some doctrine and precedent available to it, for another entirely open-ended judicial inquiry. ${ }^{196}$ Nothing would be gained in terms of textual legitimacy or judicial competence, and it is hard to imagine what other advantages would stem from a

193. See, e.g., Bruce Buchanan, The Presidency and the Nominating Process, in THE PResidency AND the Political System 251, 253-58, 261 (Michael Nelson ed., 2000) (describing changes in the presidential nomination process, and in the role of the political parties within it, over time); A.E. Dick Howard, Garcia and the Values of Federalism: On the Need for a Recurrence to Fundamental Principles, 19 GA. L. REV. 789, 793 (1985) (arguing that changes in the overall political structure have wrought "a palpable decline in the "political' safeguards" of federalism; "[p]olitical parties, especially at the state level, no longer are the force they once were. Increased use of primaries and the impact of 'reforms' have had the unintended consequence of encouraging the development of alternative institutions"). Indeed, Kramer concedes that "the parties' effectiveness in safeguarding state government may have been compromised to some degree by twentieth-century developments." Kramer, Political Safeguards, supra note 16 , at 283 .

194. See, e.g., Samuel Issacharoff \& Pamela S. Karlan, The Hydraulics of Campaign Finance Reform, 77 TEX. L. REV. 1705, 1714 (1999) ("We are particularly worried that [campaign finance] reforms would exacerbate the already disturbing trend toward politics being divorced from the mediating influence of candidates and political parties."); Howard, supra note 193, at 793 (observing that "[ $\mathrm{t}]$ he 'nationalization' of campaign finance has led to the weakening of the federal lawmakers' loyalties to constituents. Special interest politics has tended to replace consensus politics."); see also Frank J. Sorauf, Politics, Experience, and the First Amendment: The Case of American Campaign Finance, 94 Colum. L. REV. 1348, 1365 (1994) (describing past efforts at campaign finance reform as "the classic illustration of the law of unanticipated consequences").

195. See Antonin Scalia, A Matter of Interpretation: Federal Courts And the LAW 40 (1997) (suggesting that the "whole purpose [of the Constitution] is to prevent changeto embed certain rights in such a manner that future generations cannot readily take them away"). For a similar argument against exclusive reliance on political parties to protect federalism, see Prakash \& Yoo, supra note 16, at 1480-89 (concluding that "[Professor Kramer's] work relies on an extraconstitutional structure of politics that is so admittedly mutable and uncertain that it only proves our point: more permanent mechanisms, such as judicial review, are necessary to safeguard federalism").

196. Given Professor Kramer's view that the Rehnquist Court's "judicially-defined limits" on national power are both "novel" and "a radical experiment in judicial activism," Kramer, Political Safeguards, supra note 16, at 290, 292, we wonder how he would describe and distinguish the "novel judicially-defined limits" on the regulation of political parties that his argument seems implicitly to require. 
world in which courts protected the political parties but not the states. $^{197}$

\section{State Versus State: The Problem of Horizontal Aggrandizement}

Even if the state-based apportionment of representation within the federal government did ensure that "the States as States" are protected against federal overreaching, this is only one facet of the problem. Most of the literature on political safeguards has focused solely on this vertical aspect of federalism, ${ }^{198}$ but the horizontal dimension is at least as important. The concern here is that in the absence of judicial review, some states will harness the federal lawmaking power to impose their policy preferences on other states to the former states' own advantage. Not only does the state-based allocation of congressional representation sometimes fail to protect minor-

197. We also question the effectiveness of the other "new" political safeguard of federalism that Professor Kramer identifies: the existence of interlocking state and federal administrative bureaucracies. Kramer, Political Safeguards, supra note 16, at 283. Although it is no doubt true that a state role in administrative implementation confers some power on state institutions, the administrative state also has undermined federalism by loosening the constitutional constraints on federal lawmaking. See Bradford R. Clark, Separation of Powers as a Safeguard of Federalism, 79 TEX. L. REV. 1321, 1327 (2001). Neither Kramer nor anyone else, to our knowledge, has done the difficult - perhaps impossible-empirical work necessary to assess how these countervailing effects net out. And because the administrative state exists largely outside the tripartite constitutional separation of powers, it is not much less protean than the political parties. We would hate to bet the benefits of a federal system on the hope that future changes in the constantly evolving administrative bureaucracy will not undermine or eliminate the ability of such institutions to protect federalism.

198. See, e.g., Garcia v. San Antonio Metro. Transit Auth., 469 U.S. 528, 550-51 (1985) (observing that "the composition of the Federal Government was designed in large part to protect the States from overreaching by Congress") (emphasis added); id. at 552 (discussing the "effectiveness of the federal political process in preserving the States' interests") (emphasis added); id. at 556 ("The political process ensures that laws that unduly burden the States will not be promulgated.") (emphasis added); Wechsler, supra note 16, at 548 ("[T]he Senate cannot fail to function as the guardian of state interests as such.") (emphasis added); id. at 558 ("[T]he role of the states in the composition and selection of the central government [] is intrinsically well adapted to retarding or restraining new intrusions by the center on the domain of the states.") (emphasis added); id. at 559 ("[T] he Court is on weakest ground when it opposes its interpretation of the Constitution to that of Congress in the interest of the states, whose representatives control the legislative process and, by hypothesis, have broadly acquiesced in sanctioning the challenged Act of Congress.") (emphasis added); Kramer, Political Safeguards, supra note 16, at 219 ("The structure of American politics does offer states considerable protection from federal overreaching, but it does so in ways quite different from those identified by Wechsler."); id. at 269 ("Rather than judicial review, it was the party system itself that supplied the desideratum necessary to protect the states and make federalism functional.") (emphasis added); id. at 286 (contending that our political system "protect[s] the states by ensuring their ability to influence national politics") (emphasis added); id. ("The states do not need an untouchable domain of judicially protected jurisdiction; they need only the capacity to compete effectively for political authority ....") (emphasis added). 
ity states against this majoritarian use of the federal lawmaking power, it often facilitates it. ${ }^{199}$

It is important to appreciate that arguments about horizontal threats to state autonomy presume that the Wechslerian political safeguards are sometimes effective vis-à-vis some vertical aspects of federalism. That is, horizontal arguments rest on the assumption that federal institutions are sometimes responsive to the preferences and interests of state governments or (more often) of interest groups geographically concentrated in particular states. ${ }^{200}$ It is this very responsiveness that creates the problem: to the extent that Congress responds to the preferences of a majority of states, it may take action that encroaches on the autonomy of a minority of dissenting states. Such encroachment minimizes the benefits of federalism by creating a federally imposed homogenization of preferences.

1. Incentives for Horizontal Aggrandizement. Why would some states seek to use federal power as an instrument for imposing their preferences on other states? ${ }^{201}$ We can think of at least three different, if not entirely discrete, scenarios in which such encroachment might occur. The first and simplest involves a situation in which people in some states simply do not approve of certain activities permitted in other states, even though the activity in the other states does not affect them directly. When Arizona, New Mexico, Oklahoma, and Utah entered the Union, for example, Congress required each, as a condition of admission, to include in its state constitution a provision stat-

199. Baker, Conditional Federal Spending, supra note 161, at 1939-47; Baker, Spending Power, supra note 15, at 199-225.

200. It is important to distinguish here between congressional responsiveness to geographically concentrated private interests and responsiveness to state governments. We have argued, in line with other of Professor Wechsler's critics, that federal institutions may be responsive to geographically concentrated private interests without being responsive to the institutional interests of state governments. See supra notes 182-86 and accompanying text; Kramer, Political Safeguards, supra note 16, at 223 (arguing that allocating congressional representation by states "may enhance the power of geographically defined interests at the federal level, [but] does so in a way that is likely, if anything, to diminish the institutional role of state government"). Thus, private interests might be able to use the federal lawmaking process to impose horizontal encroachments on the autonomy of certain states even if the federal political process is not generally responsive to state governmental or institutional interests. This means that vertical "safeguards" may function as instruments of horizontal aggrandizement while still not offering much protection for state governmental institutions against vertical encroachments. Nonetheless, we refer to the preferences of "states" in this section as a convenient shorthand.

201. Baker, Conditional Federal Spending, supra note 161, at 1942-47 (discussing circumstances under which a state's congressional representatives might prefer to enact a conditional rather than unconditional offer of federal funds to the states). 
ing that polygamy is "forever prohibited." ${ }^{202}$ As Justice Scalia has pointed out, this requirement amounted to an "effort by the majority of citizens to preserve its view of sexual morality ... against the efforts of a geographically concentrated and politically powerful minority to undermine it." ${ }^{203}$ The preferences of polygamists in the new western states, however, did not "undermine" the marriage laws of the majority of states in any direct sense. Rather, the majority states seem to have acted out of a straightforward desire to impose their own moral code on others in the absence of a constitutional amendment reflecting a nationwide consensus on the issue.

A second scenario involves an attempt by some states to capture a disproportionate share of federal monetary or regulatory largesse. Any conditional offer of federal funds, for example, is highly likely to make some states better off at the expense of other states. ${ }^{204}$ Such an offer implicitly divides the states into two groups: (1) states that already comply, or that without financial inducement would happily comply, with the funding condition, and for which the offer of federal money therefore poses no real choice; and (2) states that find the funding condition unattractive and therefore face the choice of foregoing the federal funds to avoid complying with the condition or submitting to undesirable federal regulation to receive the offered funds. One therefore would expect such conditional funding legislation to be enacted only if a (substantial) majority of states fall within the first group: that is, they already willingly comply with, or favor, the stated condition, and the conditional offer of funds is therefore no less attractive to them than a similar unconditional offer. For the states in the majority (and their congressional representatives), a vote in favor of the conditional grant is nearly always a vote to impose a

202. Arizona Enabling Act, ch. 310, 36 Stat. 557, 569 (1910); New Mexico Enabling Act, ch. 310, 36 Stat. 557, 558 (1910); Oklahoma Enabling Act, ch. 3335, 34 Stat. 267, 269 (1906); Utah Enabling Act, ch. 138, 28 Stat. 107, 108 (1894). The complying state constitutional provisionswhich are still in force-may be found at ARIZ. CONST. art. XX, II 2; N.M. CONST. art. XXI, § 1; OKLA. CONST. art. I, $\S 2$; UTAH CONST. art. III, $\S 1$. Indeed, the Arizona, New Mexico, and Utah enabling acts required that these provisions be "irrevocable without the consent of the United States and the people of said State." Arizona Enabling Act, ch. 310, 36 Stat. at 569; New Mexico Enabling Act, ch. 310, 36 Stat. at 558; Utah Enabling Act, ch. 138, 28 Stat. at 108.

203. Romer v. Evans, 517 U.S. 620, 648 (1996) (Scalia, J., dissenting). The majority's opposition to polygamy may be traceable to abolitionist ideology as well as sheer anti-Mormon sentiment. See Akhil Reed Amar, Race, Religion, Gender, and Interstate Federalism: Some Notes from History, 16 QUINNIPIAC L. REV. 19, 24 (1996) (asserting that in 1865 the Republican party considered slavery a form of polygamy).

204. For a more extensive discussion of this argument, see Baker, Conditional Federal Spending, supra note 161, at 1939-51; Baker, Spending Power, supra note 15, at 212-17. 
burden solely on other states. Whether a state that finds the funding condition unattractive (and is therefore in the minority) chooses to decline the offer of federal funds or to acquiesce in the stated condition, those states in the majority may well improve, and will only rarely worsen, their competitive position relative to that state. ${ }^{205}$

An example will make the phenomenon more concrete. If most states already have set their minimum drinking age at twenty-one, for example, then those states should find it attractive to impose a drinking age condition on federal highway funds. ${ }^{206}$ Such a condition would bring about one of two possible results. Either outlier states with minimum drinking ages lower than twenty-one will comply with the condition, accepting the preferences held by the dominant majority, or they will forfeit whatever amount of highway funds are tied to the condition. The latter result, of course, would leave more funds available for those states in the majority. The ability to impose spending conditions thus presents states in the majority with a "no lose" proposition-"no lose," that is, except to the extent that such measures undermine the autonomy of all states in the long run.

A final scenario arises when states seek federal regulation to avoid externalities or other collective action problems associated with regulating a particular subject at the state level. Consider, for example, a not-so-hypothetical state of affairs under which a majority of the states wishes to discourage homosexual relationships. A solid majority of the citizens in each of these states may share this preference and support state laws making clear that gay partners are not entitled to family benefits, that gay couples cannot adopt children, and the like. Nonetheless, the leaders of these states may know that many private companies are more progressive on these issues and that the minority states that refuse to enact such anti-homosexual laws will have an advantage in attracting corporate facilities to their state. The states in the majority thus may seek to enact their anti-homosexual social preferences at the federal level. The primary goal here, unlike in the first scenario discussed above, need not be the imposition of the majority states' moral code on the remaining states or the preservation by the majority states' citizens of their view of sexual morality against the efforts of a politically powerful minority to undermine it.

205. By "competitive position" here we mean a state's position, relative to other states, in the competition for individual and corporate residents and their tax dollars.

206. South Dakota v. Dole, 483 U.S. 203 (1987); see Baker, Conditional Federal Spending, supra note 161, at 1943-45, 1978-87 (discussing Dole). 
Although the federal legislation that the majority states seek may have these effects, the states' primary motivation under this third scenario is to "level the playing field." Such anti-homosexual federal legislation will restrict the competition for residents and tax dollars that would otherwise exist among the states on this issue and will divest the minority states of any competitive gains afforded by their preference not to enact similar anti-homosexual legislation at the state level. ${ }^{207}$

2. The Fugitive Slave Laws as Horizontal Aggrandizement. If the hypothetical example offered above sounds extraordinary or implausible, it may help to consider a historical example of federal law adopted at the behest of a politically powerful bloc of states in order to avoid collective action problems that plagued regulation at the state level. We have in mind the sordid history of the southern states' attempts to preserve their state-law slavery regimes by requiring free states to return escaped slaves to their masters. Under the Articles of Confederation, "the recapture of fugitive slaves who escaped from the state in which they owed labor or service to another state was a matter of comity among the states. The state to which a slave fled was free to emancipate her or to return her, as it saw fit." states thus pressed at the Constitutional Convention for a provision that would solidify the right to recapture. This effort bore fruit in the Fugitive Slave Clause, which provides that "No Person held to Service or Labour in one State, under the Laws thereof, escaping into another, shall, in Consequence of any Law or Regulation therein, be discharged from such Service or Labour, but shall be delivered up on Claim of the Party to whom such Service or Labour may be due."209

207. See generally Charles M. Tiebout, A Pure Theory of Local Expenditures, 64 J. PoL. ECON. 416 (1956). For commentary on Tiebout's classic model, see, e.g., CLAYTON P. GILLETTE \& LYNN A. BAKER, LOCAL GOVERNMENT LAW: CASES AND MATERIALS 384-85 (2d ed. 1999) (collecting sources); Vicki Been, "Exit" as a Constraint on Land Use Exactions: Rethinking the Unconstitutional Conditions Doctrine, 91 ColuM. L. REV. 473, 514-18 (1991) (offering a critique and collecting sources); Gerald E. Frug, City Services, 73 N.Y.U. L. REV. 23, 25-33 (1998) (offering a critique of the "theory of public goods," including Tiebout's article).

208. Robert J. Kaczorowski, The Tragic Irony of American Federalism: National Sovereignty Versus State Sovereignty in Slavery and in Freedom, 45 U. KAN. L. REV. 1015, 1025 (1997).

209. U.S. CONST. art. IV, $\S 2, \mathrm{cl} .3$. There is some debate about how hard the South pressed for this provision. Justice Story thought that "it constituted a fundamental article, without the adoption of which the Union could not have been formed." Prigg v. Pennsylvania, 41 U.S. (16 Pet.) 539, 611 (1842); see also Wright v. Deacon, 5 Serg. \& Rawle 61, 61-62 (Pa. 1819) (“[O]ur southern brethren would not have consented to become parties to a constitution ... unless their property in slaves had been secured."). Scholars have recently contested that judgment. See, e.g., 
The Fugitive Slave Clause, like many federal laws, is designed to overcome a collective action problem. It is hard to maintain a regime of slavery when the victims of that regime can escape bondage by fleeing to nearby free states. Hence, as Justice Story explained in Prigg v. Pennsylvania, "the object of [the Fugitive Slave] clause was to secure to the citizens of the slaveholding states the complete right and title of ownership in their slaves, as property, in every state in the Union into which they might escape from the state where they were held in servitude." ${ }^{210}$ The slavery regime could not be maintained unless state laws making it difficult to recapture escaped slaves in free states were suppressed; hence, the Clause's "true design was to guard against the doctrines and principles prevalent in the non-slaveholding states, by preventing them from intermeddling with, or obstructing, or abolishing the rights of the owners of slaves." ${ }^{211}$ The Clause thus, as Robert Kaczorowski observes, "conferred on slaveowners a new constitutional property right enforceable under the authority of the national government, independent of the states, and the states were prohibited from interfering with this right."212

Barbara Holden-Smith, Lords of Lash, Loom, and Law: Justice Story, Slavery, and Prigg v. Pennsylvania, 78 CORNELL L. REV. 1086, 1129-31 (1993) (suggesting that the Fugitive Slave Clause was not central to the formation of the Union); DON FEHRENBACHER, THE DreD SCOTT CASE 25 (1978) (opining that the Fugitive Slave Clause was not an important issue at the Constitutional Convention); see also Paul Finkelman, Sorting Out Prigg v. Pennsylvania, 24 RUTGERS L.J. 605, 613 (1993) (observing that "[t]he initial response" to South Carolina's proposal for a fugitive slave provision "was hostile," but that the Convention adopted a similar draft provision a day later "with neither debate nor a formal vote"). Whether or not the issue was a constitutional deal-breaker, the crucial point for our analysis is that the measure was adopted at the behest of a politically powerful bloc of states. Earl M. Maltz, Slavery, Federalism, and the Structure of the Constitution, 36 AM. J. LEGAL Hist. 466, 471 (1992). And even if the original Fugitive Slave Clause did not arouse significant northern opposition at the Convention, enforcement of the Clause and the 1793 Act implementing it did. "Northern resistance," according to Professor Kaczorowski, "led to Southern demands for a more effective federal statute" which the South finally obtained as part of the Compromise of 1850. Kaczorowski, supra note 208, at 1035; see also Holden-Smith, supra, at 1118 n.192 ("Because of the ineffectiveness of the 1793 Act, Southern slaveholders continually agitated in Congress for a new fugitive slave law, but their efforts proved unsuccessful until 1850.”).

210. Prigg, 41 U.S. (16 Pet.) at 611.

211. Id.

212. Kaczorowski, supra note 208, at 1025. As Earl Maltz has explained, "the fugitive slave clause clearly restricts the freedom of state governments to define the status of some individuals - runaway slaves - within the territorial limits of their power. A federal standard thus displaces preexisting state authority in contravention of the general principle of state autonomy." Maltz, supra note 209, at 471. Professor Maltz thus concludes that "the clause must be considered both proslavery and nationalistic." Id. 
Southern states thus were able to impose a regime of strong recapture rights on the northern states in much the same way that our horizontal model envisions. ${ }^{213}$ When northern states attempted to mitigate this regime by creating due process protections for suspected escapees seized in their territory, the South procured a series of increasingly harsh federal statutes to implement the Clause, ${ }^{214}$ Prigg, for example, held that the Fugitive Slave Act of 1793 preempted Pennsylvania's "liberty law," which had required a more demanding evidentiary showing by slave hunters than did the federal Act. ${ }^{215}$ These federal statutes, moreover, imposed significant burdens on the citizens of free states. As Barbara Holden-Smith recounts, the federal fugitive slave laws' failure to provide meaningful due process encouraged the kidnapping of free black citizens of northern states so that they could be sold into slavery in the South. ${ }^{216}$

The federal fugitive slave laws-and the constitutional provision from which they sprung-are characteristic examples of horizontal aggrandizement in that they defeated the option of exit which is normally a fundamental attribute of federalism. ${ }^{217}$ Not only did they make

213. The fact that this regime was imposed initially in the Constitution itself does not make it a less compelling example of horizontal aggrandizement. The important point is that the southern states saw the proposed federal government as an appropriate instrument for imposing their preferred policy on other states.

214. Kaczorowski, supra note 208, at 1025-38 (recounting the history of the Fugitive Slave Act of 1793 and its more extreme successor statute enacted in 1850).

215. Prigg, 41 U.S. (16 Pet.) at 618. Justice Story also held the Pennsylvania law unconstitutional outright under the Fugitive Slave Clause. Id. at 625-26. The practical legacy of Prigg is contested; some have argued that Prigg actually made fugitive slave laws more difficult to enforce by holding that they could be enforced only by the federal courts, while others have contested this view. See Holden-Smith, supra note 209, at 1089 (collecting sources). This dispute, however, is irrelevant to our characterization of the federal fugitive slave laws as horizontal aggrandizement. There is no doubt that the slave states thought a strong fugitive slave law would further their interests, whether or not Justice Story's exclusive interpretation furthered that policy.

216. Holden-Smith, supra note 209, at 1087. Indeed, Margaret Morgan-the person kidnapped, along with her family, by Edward Prigg and his accomplices-may well have been legally free under either Pennsylvania or Maryland law. Finkelman, supra note 209, at 610-11. As Professor Finkelman observes, "[t]he circumstances of Morgan and her children underscore the necessity of state laws to protect free blacks who might be enslaved under the color of federal law." Id. at 611 n.25; see also Holden-Smith, supra note 209, at 1119-20 (observing that Pennsylvania's liberty law "was meant to thwart kidnappers of free blacks," although "it also had the additional, and perhaps unintended, effect of making it difficult for slave catchers to remove persons who actually were fugitive slaves").

217. On exit, see, e.g., Richard A. Epstein, Exit Rights Under Federalism, 55 LAW \& CONTEMP. PROBS. 147, 150 (Winter 1992) (observing that "[f]ederalism works best where it is possible to vote with your feet"); Baker, Conditional Federal Spending, supra note 161, at 194751 (discussing the relationship between individual mobility and the benefits of federalism); Seth 
escape from state-law slavery regimes in the South more difficult, they also tended to deprive free blacks of the benefits of antislavery regimes in the North by facilitating kidnappings in those states. We hasten to add, of course, that a regime of state-by-state diversity on the slavery question is morally - and ultimately proved historicallyunacceptable. ${ }^{218}$ The fugitive slave laws remind us, however, that there are even worse things-such as a uniform proslavery regime imposed on all states by the federal government. ${ }^{219}$

3. "Good" Aggrandizement, "Bad" Aggrandizement, and the "Procedural" Safeguards of Federalism. The net result of the federal legislation in each of the scenarios discussed above is a reduction in the diversity among the fifty states in the package of taxes and services, including constitutional rights and other laws, that each offers its residents and potential residents. Some individuals (and corporations) may no longer find any state that provides a package (including the permissibility of polygamy, a minimum drinking age of eighteen, the availability of various family benefits for homosexual partners, or free soil laws) that suits their preferences, while other individuals and corporations may confront a surfeit of states offering a package (including prohibitions on polygamy, a minimum drinking age of twenty-one, laws restricting various family benefits to married couples of different genders, or fugitive slave laws) they find attractive.

In many instances, this reduced diversity is likely to mean a decrease in aggregate social welfare, since the loss in welfare to those with the minority preference is unlikely to yield a comparable gain in welfare for those who favor it. ${ }^{220}$ But it is important to understand

Kreimer, Federalism and Freedom, 574 AnNALs AM. ACAD. POL. \& SOC. SCI. 66, 72 (2001) (same); Michael W. McConnell, Federalism: Evaluating the Founders' Design, 54 U. CHI. L. REV. 1484, 1493-94, 1503 (1987) (same). For those slaves who managed, through remarkable courage and fortitude, to make it north without legal exit rights, federal preemption of state laws designed to protect fugitives was a particularly cruel blow.

218. See infra Part IV.B (arguing that the Reconstruction Amendments appropriately committed the nation to resolving issues of racial oppression primarily through uniform notions of equality adopted and enforced at the federal level).

219. John Quincy Adams, for example, read Prigg to stand for "the transcendent omnipotence of slavery in these United States, riveted by a clause in the Constitution." 9 MEMOIRS OF JOHN QUINCY ADAMs 335 (Charles Francis Adams ed., 1876), quoted in Finkelman, supra note 209 , at 629.

220. That is, the mere existence of the last remaining state in which polygamy is legal, the minimum drinking age is eighteen, homosexual couples are eligible for family benefits, or former slaves are free seems likely to yield aggregate benefits for individuals with those (minority) preferences that are far greater than the aggregate benefits that individuals with the opposing, 
that, although we have deliberately chosen unattractive (especially to liberals) examples for our initial exposition, we also could cite horizontal encroachments, both historical and hypothetical, that seem much more legitimate and appealing. The northern states' efforts to end slavery, for example, are surely an instance of our first type of scenario: the North did not attack slavery primarily in Virginia or Georgia or Alabama because it harmed citizens of Massachusetts or, due to some collective action problem, undermined Massachusetts's ability to enact an effective free soil regime in its own state. Rather, the North sought to impose its antislavery preferences on the South because its citizens firmly believed slavery was wrong and were unwilling to tolerate diversity on that point.

Likewise, states sometimes may have a legitimate interest in having certain conditions imposed on federal funds offered to the states. ${ }^{221}$ If an outlier state is pursuing policies that tend to undermine the efficacy of moneys provided for a federal program, other states legitimately might object that the common federal funds are not being efficiently spent and impose a funding condition to redress the problem. A majority of states could insist, for example, that federal highway funding be reserved for those states that adhere to certain minimum safety standards in roadway design. ${ }^{222}$

Finally, the need to overcome externalities and other collective action problems-our third scenario-is one of the classic justifica-

majority preferences would realize if there were fifty rather than forty-nine states with laws consistent with those majority preferences. Indeed, for a slave, the last remaining "free soil" state likely had a value beyond measure. Of course, the precise measure and calculation of the actual welfare gains and losses in any of these situations is not currently possible, so the above claim seems unlikely to progress any time soon beyond the status of an open empirical question and a theoretical likelihood. Baker, Conditional Federal Spending, supra note 161, at 1970-71 \& n.279.

221. One of us previously has drawn a distinction between "reimbursement spending" and "regulatory spending" legislation. In the case of "reimbursement spending" legislation, the attached conditions simply specify the purpose for which the states are to spend the offered federal funds, and the legislation reimburses the states, in whole or in part, for their expenditures for that purpose. All other legislation that offers the states federal funds pursuant to other types of conditions is "regulatory spending" legislation. Baker, Conditional Federal Spending, supra note 161, at $1916 \mathrm{n} .16$. For an extended discussion of why reimbursement spending legislation is likely always to be constitutionally unproblematic, while regulatory spending legislation will be so less often, see $i d$. at 1962-78.

222. South Dakota v. Dole, 483 U.S. 203, 215 (1987) (O’Connor, J., dissenting) ("When Congress appropriates money to build a highway, it is entitled to insist that the highway be a safe one."); see also Baker, Conditional Federal Spending, supra note 161, at 1961-62 (discussing O'Connor's attempt to distinguish between constitutional and unconstitutional conditions attached to offers of federal funds to the states). 
tions for federal action. ${ }^{223}$ We have tried to suggest that such federal action is not always a good thing, but there surely are many examples where it is beneficial. ${ }^{224}$ Two states sharing a border may have different preferences regarding the regulation of pollution; where smog from the more permissive state crosses the border, it is not obviously illegitimate for the more restrictive state to seek federal regulation that would eliminate the externality-producing disparity. Our point is simply that elimination of externalities is not intrinsically good; adoption of a uniform federal rule in such circumstances does not generally require only that the externality-producing state internalize the costs of those externalities, but also that the state conform to the regulatory preferences of the majority. That, as we saw in Prigg, is not always a good thing. ${ }^{225}$

Telling the difference between good horizontal encroachments and bad ones will not always be an easy task. The important point for present purposes, however, is that we cannot necessarily expect the national political process to distinguish accurately between the two types. ${ }^{226}$ The traditional literature on federalism provides no reason to think that the aspects of the federal structure that usually are identified as guarding against vertical aggrandizement-particularly the re-

223. See DAvid L. Shapiro, Federalism: A Dialogue 45-46 (1995) (illustrating how externalities may hobble state and local governments); Bednar \& Eskridge, supra note 105, at 1469-70 (discussing the need for the federal government to discourage destructive interstate competition); Donald H. Regan, How to Think About the Federal Commerce Power and Incidentally Rewrite United States v. Lopez, 94 MiCH. L. REV. 554, 555 (1995) (arguing that federal action is constitutional when it is designed to address collective action problems).

224. Welfare benefits and environmental law are the two most obvious examples. See William J. Baumol \& Wallace E. OAtes, Economics, Environmental Policy, and THE QUALITY OF LIFE 75-79 (1979) (giving a classic depiction of environmental pollution as an uninternalized externality); PAul E. Peterson, The Price of Federalism 121-24 (1995) (arguing that devolution of welfare responsibility to the states induces a "race to the bottom" because of interstate competition to avoid becoming a "welfare magnet"); Sheryll D. Cashin, Federalism, Welfare Reform, and the Minority Poor: Accounting for the Tyranny of State Majorities, 99 COLUM. L. REV. 552, 552 (1999) (arguing for "a more aggressive framework of national [welfare] standards or incentives that would insulate the disadvantaged poor from the tyranny of the advantaged majority"); Daniel C. Esty, Revitalizing Environmental Federalism, 95 MICH. L. REV. 570, 652 (1996) (arguing for a federal structure of environmental regulation in which regulatory responsibilities are spread across various levels of government); see also infra note 359 .

225. See supra notes $210-19$ and accompanying text.

226. Current constitutional law is most cognizant of horizontal tensions among the states in the area of dormant Commerce Clause doctrine. See, e.g., Fulton Corp. v. Faulkner, 516 U.S. 325, 330 (1996) ("In its negative aspect, the Commerce Clause "prohibits economic protectionism-that is, "regulatory measures designed to benefit in-state economic interests by burdening out-of-state competitors."”" (quoting Associated Indus. v. Lohman, 511 U.S. 641, 647 (1994))). That area, of course, is characterized by particularly aggressive judicial review. 
sponsiveness of Congress and the president to interests concentrated at the state level-will provide a bulwark against horizontal aggrandizement. Indeed, as one of us has explained at length elsewhere, those political safeguards are the very instruments of horizontal impositions. ${ }^{227}$

This is not to say that the national political process raises no impediment at all to horizontal encroachments on the autonomy of individual states. Brad Clark recently rethought Professor Wechsler's argument by emphasizing the Constitution's demanding procedural requirements for the creation of federal law. "Each set of procedures," Professor Clark argues, "requires the participation and assent of multiple actors to adopt federal law. This creates the equivalent of a supermajority requirement and thus reinforces the burden of inertia against federal action, leaving states greater freedom to govern." ${ }^{228}$ Because they operate simply by making the creation of federal law difficult, these "procedural" safeguards of federalism ought to throw up roadblocks to horizontal as well as vertical forms of aggrandizement.

We are inclined to agree with Professor Clark's view that the operation of these "procedural safeguards," combined with the traditional safeguards Professor Wechsler identifies, are likely to afford significant protections for state autonomy. ${ }^{229}$ We note, however, that Professor Clark does not appear to argue that reliance on procedural checks should be exclusive of substantive judicial review. ${ }^{230}$ Indeed, Professor Clark advocates judicial review in a multitude of contexts to maintain and reinforce the procedural safeguards he identifies; he applauds, for instance, the Court's searching judicial scrutiny of legisla-

227. Baker, Conditional Federal Spending, supra note 161, at 1939-47; Lynn A. Baker \& Samuel H. Dinkin, The Senate: An Institution Whose Time Has Gone?, 13 J.L. \& POL. 21 (1997); Baker, Spending Power, supra note 15, at 199-217.

228. Clark, supra note 197, at 1339; see also Ernest A. Young, Constitutional Avoidance, Resistance Norms, and the Preservation of Judicial Review, 78 TEX. L. REV. 1549, 1609 (2000) ("[T] he ultimate political safeguard may be the procedural gauntlet that any legislative proposal must run and the concomitant difficulty of overcoming legislative inertia."). These procedures, as Professor Clark points out, also have the effect of channeling decisionmaking to Congress (where the states are represented) and away from federal administrative agencies (where they are not). Clark, supra note 197, at 1339 (noting that "each procedure limits participation to actors-such as the Senate-originally structured to be responsive to state prerogatives").

229. See generally Young, Two Cheers, supra note 93.

230. Professor Clark seems to go no further than to suggest that "strict adherence to federal lawmaking procedures arguably has a 'larger influence upon the working balance of our federalism' than the formal 'distribution of authority between the nation and the states."' Clark, supra note 197, at 1325 (quoting Wechsler, supra note 16, at 544). 
tive self-delegation ${ }^{231}$ and even suggests a continuing role for the nondelegation doctrine. ${ }^{232}$ To be sure, these forms of judicial review traditionally have been thought to involve separation of powers, not federalism. But Professor Clark's central point-that separation of powers $i$ an aspect of federalism ${ }^{233}$ - undermines the very idea of a double standard between the two issues.

The types of judicial review upon which Professor Clark focuses, moreover, reinforce Justice O'Connor's broader vision of the judiciary as "a prudent umpire, who allows the contestants to play hard between the lines but takes swift and sure action when those lines are crossed." ${ }^{234}$ The central claim of political safeguards theorists is that the Constitution provides the various actors in the system with the power and opportunity to check one another politically. Those checks cannot operate effectively or indefinitely, however, if the basic rules of the system are not respected-and those rules include principles such as the limited nature of federal legislative power. ${ }^{235}$ Substantive judicial review of federalism issues is necessary both to remind Congress of its own obligation to restrain itself ${ }^{236}$ and to catch any particularly egregious examples of federal overreaching that slip through the system's political and procedural checks.

\section{Political Safeguards and the Double Standard}

A final problem with the political safeguards argument is its failure to explain the cases-that is, the many instances in which courts

231. Id. at 1379-86 (citing INS v. Chadha, 462 U.S. 919 (1983); Bowsher v. Synar, 478 U.S. 714 (1986); and Metro. Wash. Airports Auth. v. Citizens for the Abatement of Aircraft Noise, 501 U.S. $252(1991))$.

232. Id. at $1373-78$.

233. The title of the article, after all, is "Separation of Powers as a Safeguard of Federalism." Id. at 1321.

234. O'Connor, supra note 107 (manuscript at 7).

235. One of us has argued elsewhere that the Framers' vision of "political safeguards" relies on the people's loyalty to state governments, which is in turn predicated upon the states' ability to provide government services and beneficial regulation to their citizens. The limited nature of federal power precludes the federal government from preempting the sources of that loyalty; it follows, however, that allowing the federal government to exceed its limited powers would undermine the very basis of the "political safeguards of federalism." See Young, State Sovereign Immunity, supra note 114, at 43-47; see also Robert F. Nagel, Federalism as a Fundamental Value: National League of Cities in Perspective, 1981 SUP. CT. REV. 81, 100 (making a similar argument); Young, Two Cheers, supra note 93, at 1367-73 (same).

236. Bednar \& Eskridge, supra note 105, at 1484 (arguing that Lopez "is best read as a remand for Congress to attend to federalism values more explicitly"); Young, Two Cheers, supra note 93, at 1390-91 (arguing that Congress is unlikely to respect state autonomy politically if the judiciary tells Congress that its power is unlimited). 
engage in judicial review despite the theoretical availability of political protections for the values in question. Justice Powell's Garcia dissent noted two prominent examples of this problem: courts review separation of powers issues, despite the fact that the president and Congress each have ample political means at their disposal to protect themselves against one another, ${ }^{237}$ and courts review individual rights issues, despite the fact that the whole point of our political processes is to represent individuals. ${ }^{238}$ Any argument that judges should refrain, for lack of necessity, from enforcing federalism must somehow explain why enforcement continues in these other areas.

Take separation of powers first: one of the most glaring weaknesses of Justice Blackmun's opinion in Garcia was its failure to distinguish Buckley v. Valeo ${ }^{239}$ or Myers v. United States, ${ }^{240}$ two cases in which "a much stronger argument as to inherent structural protections could have been made." ${ }^{241}$ As Justice Powell noted in his dissent, prior to Garcia the Court had "never before abdicated responsibility for assessing the constitutionality of challenged action on the ground that affected parties theoretically are able to look out for their own interests through the electoral process. ${ }^{242}$ In both Buckley and Myers, "the President signed legislation that limited his authority with respect to certain appointments." 243 Although, arguably, "it was ... no concern of [the] Court that the law violated the Constitution," ${ }^{244}$ the Court "nevertheless held the laws unconstitutional because they infringed on Presidential authority, the President's consent notwithstanding." 245

The aggressive judicial enforcement of separation of powers has continued since Garcia. Sometimes, the Court has purported merely to be implementing the uncompromising commands of determinate

237. Garcia v. San Antonio Metro. Transit Auth., 469 U.S. 528, 567 n.12 (1985) (Powell, J., dissenting).

238. Id. at 565 n.8; Reynolds v. Sims, 377 U.S. 533, 562 (1964) ("Legislators represent people, not trees or acres. Legislators are elected by voters, not farms or cities or economic interests.").

239. 424 U.S. 1 (1976).

240. 272 U.S. 52 (1926).

241. Garcia, 469 U.S. at 567 n.12 (Powell, J., dissenting).

242. Id.

243. Id.

244. Nat'l League of Cities v. Usery, 426 U.S. 833, 841 n.12 (1976) (paraphrasing the "political safeguards" argument of Justice Brennan's dissent).

245. Garcia, 469 U.S. at 567 n.12 (Powell, J., dissenting). 
constitutional text; in INS v. Chadha ${ }^{246}$ and Clinton v. New York, ${ }^{247}$ for example, the Court argued that the detailed lawmaking procedure set forth in Article I simply leaves no room for innovation. If these were the only cases, one might seek to draw a line by analogy between those federalism limitations that are explicitly set forth in constitutional text and those that are not.$^{248}$ But these are not the only separation of powers cases; on other occasions, the Court has shown itself willing to conduct quite open-ended inquiries into whether a given structural innovation-like the independent counsel statute ${ }^{249}$ or the Federal Sentencing Commission ${ }^{250}$ - upsets the overall balance of separation of powers by either aggrandizing one branch or encroaching upon the turf of another. ${ }^{251}$ While these more "functionalist" inquiries tend to result in upholding the statutory innovation in question, ${ }^{252}$ they certainly engage in more searching review than contemporary opponents of federalism would sanction.

To be fair, some proponents of the political safeguards argument have embraced Justice Powell's criticisms and (instead of upholding judicial enforcement in both contexts) have suggested that the courts should stop enforcing most separation of powers principles as well. ${ }^{253}$ The Court's failure to adopt such proposals reflects, in our view, the recognition that "political" safeguards work best when judicial review plays a supporting role by enforcing the basic rules of political competition. Garcia thus, in Professor Van Alstyne's words, "involve[d] a double counting of what are in fact merely pre-judicial and postjudicial 'safeguards' of the American constitutional plan, safeguards (such as they are) merely additional to, and not in substitution of, sub-

\footnotetext{
246. 462 U.S. 919 (1983).

247. 524 U.S. 417 (1998).

248. One might, for instance, strictly enforce the Eleventh Amendment while eschewing less textual and more open-ended inquiries like the National League of Cities doctrine. But even here, the situation is complicated. Much of current Eleventh Amendment doctrine, while rulelike in structure, has little to do with the constitutional text. E.g., Young, Jurisprudence of Structure, supra note 15, at 1616-24. And the efforts of Lopez and Morrison to define the limits of "commerce" under Article I, although arguably more open-ended, do have some textual warrant behind them. Likewise, one can argue that the text did not clearly compel the results in Chadha and Clinton. See, e.g., Chadha, 462 U.S. at 980 (White, J., dissenting).

249. See Morrison v. Olson, 487 U.S. 654, 696-97 (1988).

250. See Mistretta v. United States, 488 U.S. 361, 412 (1989).

251. See also Commodity Futures Trading Comm'n v. Schor, 478 U.S. 833, 850-58 (1986) (analyzing the permissibility of allocating judicial business to a non-Article III court by way of a balancing test aimed at preventing undue aggrandizement or encroachment).

252. See Peter L. Strauss, Formal and Functional Approaches to Separation-of-Powers Questions-A Foolish Inconsistency?, 72 CORNELL L. REV. 488, 489 (1987).

253. CHOPER, supra note 28, at 263
} 
stantive judicial review." 254 In any event, even the more consistent (and therefore radical) proponents of political safeguards have a difficult time embracing Justice Powell's second analogy. If the states' representation in Congress is sufficient to reject judicial review for federalism issues, Justice Powell pointed out, one might similarly argue that "because Congress is composed of individuals, individual rights guaranteed by the Bill of Rights are amply protected by the [federal] political process." 255

At first glance, the analogy seems more clever than persuasive. Of course the courts sit to protect the constitutional rights of individuals, because our unfortunate experience is that even a political majority committed to individual rights in the abstract may seek to suppress those rights in particular instances. The Federalist Congress that drafted the Bill of Rights, after all, also enacted the Alien and Sedition Acts. ${ }^{256}$ But it is possible to accommodate these concerns and still have a political safeguards argument against judicial review in a wide variety of individual rights cases. That is the thrust of John Hart Ely's position in Democracy and Distrust: courts should closely scrutinize governmental action bearing on individual rights if and only if the rights restricted are themselves integral to the political process (e.g., free speech and press) or the restrictions disadvantage politically powerless minorities. ${ }^{257}$

As influential as Dean Ely's thesis has been, the courts do not really do that. Courts protect abortion and the use of contraceptives, even though solid political majorities support both practices. ${ }^{258}$ The

254. Van Alstyne, supra note 4, at 1724.

255. Garcia v. San Antonio Metro. Transit Auth., 469 U.S. 528, 565 n.8 (1985).

256. There were, of course, important discontinuities in support for the two measures. See STANLEy ElKins \& ERIC MCKITRICK, THE AgE OF FEDERALISM 60-62, 590-93 (1993).

257. ELY, supra note 32, at 101-03.

258. A recent ABC News-Beliefnet poll found that public support for abortion rights had "slipped" to 52 percent, hardly making pro-choicers an Ely-esque oppressed minority. World News Tonight (ABC television broadcast, July 2, 2001), available at http://abcnews.go.com/ sections/us/DailyNews/poll010702.html (on file with the Duke Law Journal). A recent NARAL poll found that " 87 percent of Americans support access to birth control and 77 percent support laws requiring insurance companies to cover prescription contraceptives." Congress Defies Bush, Backs Contraceptive Insurance Coverage for Federal Employees, U.S. NEWSWIRE, July 17, 2001. In fact, an important element of Justice Harlan's influential argument that contraception is constitutionally protected in Poe v. Ullman was that only a single state had made contraceptive use a crime. 367 U.S. 497, 554-55 (1961) (Harlan, J., dissenting) (finding that no state, and in fact no nation, had made contraceptive use a crime). That suggests that the Court is more willing to protect politically popular rights than those espoused only by oppressed minorities. 
courts protect commercial $\operatorname{speech}^{259}$ and political campaign expenditures, ${ }^{260}$ even though the former has an attenuated relation to the political process and the latter actually may undermine $i^{261}$ - and in any event each has the support of powerful political interests. Further, the Supreme Court is edging toward placing discrimination against women on the same plane as discrimination against racial minorities, ${ }^{262}$ despite the fact that women are, politically speaking, a vigorously courted nonminority. ${ }^{263}$

The courts have, then, rejected a political safeguards approach to individual rights despite the fact that they easily could come up with an intellectually coherent individual rights version of Professor Wechsler's argument. ${ }^{264}$ This should surprise no one; the Constitution is so full of redundant safeguards that the burden of persuasion on anyone proposing necessity as a criterion of judicial review ought to be very high. ${ }^{265}$ So, too, with federalism. As Justice O'Connor has observed, "both the 'political' and the 'judicial' safeguards of federalism reinforce the federal-state balance." 266

259. E.g., 44 Liquormart, Inc. v. Rhode Island, 517 U.S. 484, 512-13 (1996) (holding that a Rhode Island statute banning liquor advertising except at a place of sale violated the First Amendment). Although the degree of protection may-but may not, see id. at 523-28 (Thomas, J., concurring) - be less than that accorded political speech, it is still far greater than that accorded, say, economic substantive due process or-prior to Lopez-federalism values.

260. Buckley v. Valeo, 424 U.S. 1, 39-59 (1976) (per curium) (invalidating a statute imposing expenditure ceilings on political campaigns as a violation of the First Amendment); Citizens for Responsible Gov't State Action Comm. v. Davidson, 236 F.3d 1174, 1193-95 (10th Cir. 2000) (finding portions of the Colorado Fair Campaign Practices Act unconstitutional as applied).

261. See, e.g., Cass R. Sunstein, Political Equality and Unintended Consequences, 94 COLuM. L. REV. 1390, 1413 (1994) (arguing that Buckley undermined political equality).

262. See United States v. Virginia, 518 U.S. 515, 532-33 (1996) (requiring an "exceedingly persuasive" justification for gender discrimination).

263. E.g., Frank Bruni, G.O.P. Tries to Counter Lack of Support Among Women, N.Y. TIMES, Aug. 1, 2001, at A14 (highlighting the critical role of women voters in elections); Ellen R. Malcolm, Editorial, Women Leading Way for Democrats, CHI. SUN-TIMES, Jan. 27, 2001, at 17 ("Women clearly demonstrated they hold the key to victory for Democrats. Democratic female candidates were big winners in November [2000], showing they could win the most closely contested races, and across the country, female voters created the margin of victory for Democratic candidates.").

264. Nor does Professor Kramer's argument that we have done without judicial review of federalism issues for 200 years explain this double standard. After all, we did without meaningful judicial enforcement of the Free Speech Clause for most of our history as well. See, e.g., DAVID M. RABBAN, FREE SPEECH IN ITS FORGOTTEN YEARS 2 (1997) (noting "pervasive judicial hostility to virtually all free speech claims" during the long period from roughly 1800 to World War I).

265. See, e.g., The Federalist No. 51, at 323 (James Madison) (Clinton Rossiter ed., 1961) (discussing the function of federalism and separation of powers as a "double security" for liberty).

266. O'Connor, supra note 107 (manuscript at 7). 
In light of all this, the double standard's enduring appeal to critics of federalism probably has little to do with necessity. We cannot help but suspect that the reason for the disparity is that nationalists and liberals simply find most individual rights-and especially the majoritarian ones like abortion-normatively more attractive than states' rights. ${ }^{267}$ It seems likely, in other words, that the Garcia majority simply did not consider the preservation of a realm of autonomy for the states to be normatively attractive, and that it seized upon the political safeguards rationale (together with the institutional incompetence claims) as the most intellectually respectable means to that end.

Even if we thought it was acceptable to read particular values out of the Constitution simply because popular opinion at a given point in history finds them normatively unattractive-which we do not-this reasoning still would be faulty. We address the normative argument for placing federalism in constitutional "exile" in the next Part.

\section{THE NORMATIVE PROBLEM}

At the end of the day, changing normative preferences may provide a more convincing descriptive explanation for the double standard than any principled distinctions among constitutional values. Economic rights like property and contract seem so, well, bourgeois today-especially to typically left-of-center academics. So too with federalism. Edward Rubin and Malcolm Feeley, for instance, boldly assert that "there is no normative principle involved [in federalism] that is worthy of protection." 268

We doubt that these changed preferences provide a legitimate justification for ceasing to enforce particular aspects of the constitutional order. A constitution, after all, is supposed to place certain values off limits to alteration not only by populist sentiment but by intellectual fashion as well. If a particular principle is part of the Constitution, then there can be no legitimate justification for putting

267. Listen to the outright hostility in an influential diatribe against federalism by Professors Rubin and Feeley: "When federalism is raised as an argument against some national policy, we generally reject it by whatever means are necessary, including, in one case, killing its proponents. This Article describes that process, and asserts that, on grounds of political morality, it has been exactly the right thing to do." Rubin \& Feeley, supra note 93, at 908 (citing the Civil War as an example of killing federalism proponents). Would we tolerate, as within the realm of civil academic discourse, a similar comment about how to deal with proponents of racial or gender equality?

268. Id. at 909. 
it in "exile" other than a subsequent-and fairly direct-constitutional amendment. ${ }^{269}$ The current unpopularity of states' rights in the academy thus cannot itself justify the double standard of judicial review.

We consider the normative argument for the double standard at some length here because we find the widespread conviction that states' rights are normatively unattractive somewhat puzzling. We think this conviction ultimately springs from some combination of four different sources. First, the significance of the term "states' rights" and its relation to traditional liberal appreciation for diversity frequently are not appreciated or understood. Second, the historical linkage of states' rights to slavery and segregation tends to obscure the fact that federalism is largely irrelevant to those issues under current constitutional law. Third, liberals seem to assume that a particular historical configuration of political forces-i.e., Democratic party dominance of the federal government; more conservative regimes in the states-will endure forever. And finally, most observers have overlooked the distinctive interaction between federalism, individual rights, and economic regulation in contemporary law.

\section{A. States' Rights, Individual Rights, and Diversity}

A state's freedom from federal interference, like an individual's freedom from governmental restrictions on expression or private choices, is an essentially negative freedom. Just as Isaiah Berlin defined "negative freedom" for individuals as "the area in which a man can act unobstructed by others, ${ }^{, 270}$ so too federalism seeks to create a space within which a local political community can make choices about how to govern itself without interference from the national

269. It is sometimes argued that the Reconstruction Amendments profoundly altered the nature of the federal scheme by radically undermining state autonomy. See, e.g., Evan H. Caminker, State Sovereignty and Subordinacy: May Congress Commandeer State Officers to Implement Federal Law?, 95 COLUM. L. REV. 1001, 1043 n.164 (1995) ("I am personally disinclined to give much weight to the Framers' intent on issues of federalism in particular, as I believe the Reconstruction Amendments significantly changed the proper constitutional perspective on federal-state relations."). But it is hard to find any evidence of this in the text of the relevant provisions. We do not have space to develop a full-fledged theory of constitutional amendment here, but it seems to us that any reasonable version of constitutionalism must at least presume that subsequent amendments do not alter the prior structure unless they say so. We would not think, for instance, that the enforcement provisions of the Thirteenth and Fourteenth Amendment give Congress the power to suppress political speech advocating slavery or to punish persons convicted of violating the civil rights of African Americans by drawing and quartering, simply because those Amendments postdate the First and Eighth Amendments.

270. ISAIAH BERLIN, FOUR ESSAYS ON LIBERTY 122 (1969). 
government. And just as negative freedoms do not prescribe what the individual shall do within this protected sphere of liberty, so too federalism does not dictate that the state government make any particular substantive choice within the range of options permitted it.

We are cognizant, of course, of the danger of equating the rights of individuals and the rights of states. Indeed, we would be the first to concede that states' rights have no independent value; their worth derives entirely from their utility in enhancing the freedom and welfare of individuals. The question, however, is whether individual freedom can best be protected solely by assigning particular rights to individuals - such as free speech or privacy-or through a structure of institutional checks and balances, or through some combination of the two. The Framers of our Constitution, of course, began with a virtually exclusive emphasis on structural mechanisms, ${ }^{271}$ although they ultimately adopted a combination of the two approaches by ratifying a federal Bill of Rights. As Justice Kennedy recently observed,

In recent years, perhaps, we have come to think of liberty as defined by that word in the Fifth and Fourteenth Amendments and as illuminated by the other provisions of the Bill of Rights. The conception of liberty embraced by the Framers was not so confined. They used the principles of separation of powers and federalism to secure liberty in the fundamental political sense of the term, quite in addition to the idea of freedom from intrusive governmental acts. ${ }^{272}$

At no time, moreover, did the Framers suggest that an exclusive reliance on enumeration of individual rights would provide sufficient protection for individual liberty. Indeed, as Thomas McAffee observes, the Ninth Amendment may have been included in the Bill of Rights precisely to head off such an interpretation. ${ }^{273}$

271. See, e.g., THE FedERALIST No. 51, supra note 265, at 322 (James Madison) (explaining that in the proposed Constitution, "the constant aim is to divide and arrange the several offices in such a manner as that each may be a check on the other"); THE FEDERALIST No. 47, supra note 265, at 301-03 (James Madison) (describing the relationship between separation of powers and individual liberty in Montesquieu's thought); Young, Two Cheers, supra note 93, at 1353-55 (outlining the Federalists' commitment to institutional and political checks for preserving liberty).

272. Clinton v. City of New York, 524 U.S. 417, 450 (1998) (Kennedy, J., concurring); see also Thomas B. McAffee, Federalism and the Protection of Rights: The Modern Ninth Amendment's Spreading Confusion, 1996 B.Y.U. L. REV. 351, 351 ("The enormous expansion of federal power in the twentieth century has powerfully reinforced our tendency to denigrate, if not to miss completely, the framers' belief that the limited powers scheme of our federal system was an important guarantor of popular rights.").

273. See McAffee, supra note 272, at 352 ("The purpose of the Ninth Amendment was to 
One crucial feature of a system of institutional checks and balances is that the various participants in the system have rights against one another-that is, that each institution has certain trumps that it can exercise to protect its position against encroachments by other entities. ${ }^{274}$ No one is confused when we speak of Congress's "rights" vis-à-vis the president or vice versa. No one thinks we are "anthropomorphizing" Congress by such language, or that any of these institutions exists for any purpose other than to protect the freedom and welfare of individual human beings. ${ }^{275}$ The point is simply that, to act as an effective check on executive power for the benefit of the people, Congress must have certain prerogatives that are enforceable as a matter of legal "right." So, too, with states' rights: if the states are to be an effective component of Madison's "double security" for individual liberty ${ }^{276}$ then the states must have certain "rights" that the national government is bound to respect.

1. How Federalism Protects Liberty. State autonomy ultimately exists to safeguard the liberty of individuals in at least three ways. First, it creates a set of intermediary institutions that exist as a buffer between the individual and the central government. State institutions are large, well established, and provide a rallying point for opposition to federal policies. As a result, they often will raise a far more serious obstacle to illiberal measures at the federal level than could individuals acting alone or even through private associations. ${ }^{277}$ Extensive political theory and social science literatures long have linked the decline of intermediary institutions such as churches, unions, and

ensure that the system of limited powers and reserved rights embodied in the Constitution would not be overturned in favor of a government of general legislative powers subject only to the specific restrictions stated in the Constitution and its amendments."); cf. Clinton, 524 U.S. at 450 (Kennedy, J., concurring) ("It would be a grave mistake . . . to think a Bill of Rights in Madison's scheme then or in sound constitutional theory now renders separation of powers of lesser importance.").

274. See Gillette, supra note 186, at 1347-48 (describing the various ways in which such a trump might operate).

275. A reference to Congress's right to declare war should, for example, be understood to refer to the separate allocation of that function to Congress as a check on the president's own authority as commander-in-chief. That separation, in turn, is designed to preserve individual liberty. David I. Lewittes, Constitutional Separation of War Powers: Protecting Public and Private Liberty, 57 BROOK. L. REV. 1083, 1100 (1992) (arguing that federal powers are divided to secure the blessings of both public and private liberty).

276. THE FEDERALIST No. 51, supra note 265, at 323 (James Madison).

277. We need not establish that private opposition always (or even most of the time) will be less effective than state institutions. The Constitution smiles upon redundant systems. 
families to the centralization and accumulation of government power. ${ }^{278}$ To the extent that state institutions play a role in filling this gap, they provide an important safeguard for individual liberty. ${ }^{279}$

The role of the states in resisting the accumulation of power in Washington, D.C., sometimes is viewed as important only in implausible "worst case scenarios" involving the ascension of a dictator in Washington. ${ }^{280}$ Yet the states play a more prosaic checking role on a regular basis. An important element of political liberty is the openness of the system to changes in leadership, reform of government institutions, and changes in official policy. The states provide critical staging grounds for such movements; groups that are out of power at the national level nonetheless may develop political experience and support, as well as a successful record for their policies, in individual

278. See, e.g., John StUART MiLl, AUtOBIOGRAPHy 115-16 (J. Stillinger ed., Houghton Mifflin 1969) (1873) (acknowledging the importance of intermediary institutions in avoiding "the absolute rule of the head of the executive over a congregation of isolated individuals, all equals but all slaves"); LARRY SIEDENTOP, DEMOCRACY IN EUROPE 2-7 (2001) (arguing that aristocratic institutions in Europe were "in a position to defend local autonomy and limit the centralization of political power," and that the replacement of those institutions with regimes based solely on individual rights contributed to the rise of despotic central governments); ROBERT Wuthnow, MEANing AND MORAL ORdER: Explorations IN CUltural ANALYSIS 198 (1987) ("[I]ndividuation on a societal scale may serve usefully in the statebuilding process as a means of achieving social control. Autonomous individuals, simply, are likely to be easier to control than are tribes, ethnic groups, collectives, unions, or other solidary entities."); Robert N. Bellah, America's Cultural Conversation, in INDIVIDUALISM AND COMMITMENT IN AMERICAN LIFE: READINGS ON THE THEMES OF HABITS OF THE HEART 3 (Robert Bellah et al. eds., 1987) ("[W]hen people are reduced to isolated individuals . . public discussion and popular initiative will languish and decisions will be made by administrative bureaucrats in the interest of maintaining their own power."). To be sure, the relationship between state and local governments, nongovernmental intermediary institutions, and centralized authority is complex. See, e.g., Robert D. Putnam, Bowling Alone: The Collapse And REVIVAL OF AMERICAN COMMUNITY 344-49 (2000) (describing how the effectiveness of subnational governments may vary according to the presence or absence of nongovernmental intermediary institutions that build "social capital"). We cannot undertake a thorough exploration of those relationships here. Our point is simply that, as Madison recognized, state governments can serve as a rallying point for civic participation that may help mediate between the national government and isolated individuals. See, e.g., THE FEDERALIST No. 44, supra note 265, at 28586 (James Madison) (suggesting that state governments will serve as an "intermediate body" between the people and the national government and that the states will oppose on the people's behalf usurpations by the central authority).

279. See, e.g., SIEDENTOP, supra note 278, at 7-10 (summarizing and endorsing de Tocqueville's view that American federalism supplied the type of intermediary institutions necessary to prevent the centralization of power).

280. This sort of concern loomed larger in the Founding era; hence Madison's emphasis, in Federalist No. 46, on the states' ability to counteract centralized tyranny through military force. THE Federalist No. 46, supra note 265, at 298-300 (James Madison). To modern eyes, this focus sometimes "seems anachronistic because the core of the redress proposed was a confrontation at arms whose plausibility in the twenty-first century should evoke some skepticism." Kreimer, supra note 217, at 70. 
states before competing for power at the national level. As Seth Kreimer points out,

From Madison and Jefferson challenging the Alien and Sedition Acts in the legislatures of Kentucky and Virginia, to Ronald Reagan critiquing the Great Society in California, to Bill Clinton, in Arkansas, building a successful challenge to a sitting president, the existence of state-level alternatives to the nationally dominant political orthodoxy has made an electoral-if not a military-challenge to that orthodoxy more likely. ${ }^{281}$

The threat of similar challenges from opponents with independent power bases in the states, moreover, gives national politicians an incentive to be responsive to popular opinion. ${ }^{282}$

The second and third ways federalism protects liberty focus more directly on the individual. Most straightforwardly, the idea of limited and enumerated federal powers limits the intrusion of federal regulation on individual autonomy. According to Professor McAffee, "our familiarity with the modern judiciary's reliance upon specific textual rights provisions ... against otherwise valid claims of legislative authority has blinded us to the fact that civil rights claims based on a lack of governmental authority are also 'individual rights' claims." 283 The Court's decision in Lopez, for example, furthered individual liberty in a way that liberal partisans of the Warren Court ought to find familiar: the result of the decision was to invalidate a criminal conviction and let an individual out of jail. ${ }^{284}$ To be sure, a finding that a regulation exceeds Congress's powers generally will leave the subject matter open to state regulation, ${ }^{285}$ indeed, we will argue later on that the effect of much federal regulation is often to decrease the rigor of

281. Kreimer, supra note 217 , at 70-71. We would, of course, add to this list George W. Bush, who used his governorship of the Great State of Texas to launch his challenge to the Democratic administration in Washington, D.C.

282. One might argue, following the distinction between "federalism" and "decentralization" posited by Professors Feeley and Rubin, supra note 93, at 910-14, that the role of the states as staging grounds for political opposition requires only the existence of decentralized administrative units. Unless states are endowed with "trumps" that guarantee them some measure of sovereignty, however, federal politicians will be able to undermine their potential political opponents in the states by withdrawing meaningful functions from state governments.

283. McAffee, supra note 272, at 351.

284. See United States v. Lopez, 2 F.3d 1342, 1368 (5th Cir. 1993) ("Lopez's conviction must . . . be reversed . . . because his indictment did not allege any connection to interstate commerce."), aff'd, 514 U.S. 549 (1995).

285. See, e.g., Lopez, 514 U.S. at 551 (noting that Lopez initially was charged under state law before he was turned over to federal officials). 
state regulation, especially in the commercial area. ${ }^{286}$ This will not always be the case, however; in at least some instances, the recognition of limits on federal regulatory authority will increase the sphere of individual autonomy.

The third and potentially most important sense in which federalism protects liberty is by fostering different legal regimes in different states. As one of us previously has demonstrated, federalism provides an additional level of freedom to individuals, beyond that provided by specific guarantees of individual rights, by conferring the freedom to choose from among various diverse regulatory regimes the one that best suits the individual's preferences. ${ }^{287}$ Professor Kreimer illustrates the wide variety of situations in which Americans have invoked this freedom:

Mormons moved from Illinois to Utah, while African Americans migrated from the Jim Crow South. Rail travel and, later, automobiles and airplanes enabled residents of conservative states to escape constraints on divorce and remarriage. In the years before Roe $v$. Wade, women from states with restrictive abortion laws sought reproductive autonomy in more sympathetic jurisdictions. Today, the lesbian who finds herself in Utah, like the gun lover who lives in Washington, D.C., and the gambler in Pennsylvania, need only cross a state border to be free of constraining rules. These are liberties that come only with the variations in local norms made possible by federalism. ${ }^{288}$

As Professor Kreimer's examples demonstrate, this personal right of exit is a negative freedom in the sense that the right itself is indifferent in principle to the uses to which it is put. People may use it, in other words, for both attractive and unattractive purposes. This fact, however, hardly distinguishes federalism from other principles of liberty that the Court has been willing to enforce rigorously.

2. Federalism, Diversity, and Liberal Political Theory. The liberal political tradition normally has not equated the appeal of negative freedom with the normative attractiveness of that for which the

286. See infra notes 385-93 and accompanying text.

287. Baker, Conditional Federal Spending, supra note 161, at 1947-51.

288. Kreimer, supra note 217, at 72; see also supra note 208 and accompanying text. On the importance of exit rights in the American political tradition, see ALBERT O. HIRSCHMAN, EXIT, Voice, And Loyalty: Responses to DeCline in Firms, ORganizations, and STATES 106-12 (1970). 
individual chooses to use it. ${ }^{289}$ Instead, contemporary liberalism distinguishes "between the 'right' and the 'good'-between a framework of basic rights and liberties, and the conceptions of the good that people may choose to pursue within the framework." ${ }^{290}$ The "right" in this framework is typically given priority to the "good"; John Rawls argues, for example, that "it is, in general, a good thing that individuals' conceptions of their good should differ in significant ways, whereas this is not so for conceptions of right." ${ }^{\text {291 }}$ To extend Rawls's terminology to federalism, we would expect states to agree on a framework of rights ensuring their autonomy to make certain decisions ("the right"), but would expect states to differ on the social choices that they make within that framework ("the good"). In other words, freedom of choice generally will bring about diversity of outcomes.

Federalism, however, generally has been deplored for the ends to which certain groups in our history have sought to use state autonomy. ${ }^{292}$ The modern issues on behalf of which states' rights arguments frequently are deployed do not arouse much pro-state sympathy. Sometimes the issues hearken all too clearly back to the Civil War era. The recent controversy over whether the Confederate flag should fly over the South Carolina Statehouse, for example, not surprisingly generated much editorial discussion of the historical relationship be-

289. Classical conservatism frequently has been more ambivalent about this sort of negative freedom. Edmund Burke, for example, observed that "[ $\mathrm{t}]$ he effect of liberty to individuals is, that they may do what they please: we ought to see what it will please them to do, before we risk congratulations, which may be soon turned into complaints." EDMUND BURKE, REFLECTIONS ON THE REVOLUTION IN FRANCE 9 (F.G. Selby et al. eds., MacMillan 1924) (1790).

290. Michael J. Sandel, Introduction to LIBERALISM AND ITS CRITICS 3 (Michael J. Sandel ed., 1984).

291. JOHN RAWLS, A THEORY OF JUSTICE $§ 68$, at 447 (1971).

292. One might contest our analogy of federalism to a structure of "right" and the different social regimes it permits as visions of the "good." Certainly, regimes such as slavery and segregation violate just about any conception of the "right" one would care to select, so that the choices of individual states to establish such regimes would not be tolerated by liberal political theory. One answer is that the distinction between the "right" and the "good" has always been a bit fuzzy, and different people will categorize differently in some cases. A defender of federalism can happily concede that where an appropriate supermajority of the people can agree that a given principle is part of the "right"- e.g., some level of racial equality after 1868-that principle should be placed off limits to state-by-state diversity by enshrining it in the Constitution. See infra Part IV.B. But where conceptions of the "right" are contested-for instance, where we cannot agree whether one scheme of voting or another will best promote political equalitythen federalism will increase liberty by allowing people to choose freely among competing conceptions of the "right." 
tween states' rights and slavery. ${ }^{293}$ Other times defenders of states' rights find themselves opposing federal legislation with otherwise uncontroversial and attractive goals and, as a result, may seem to hold the opposing, normatively unattractive views. Thus, in recent years, the defenders of states' rights before the Supreme Court may have appeared, erroneously, to disfavor gun-free school zones, ${ }^{294}$ background checks for purchasers of fire arms, ${ }^{295}$ the imposition of civil sanctions on persons who commit violence against women ${ }^{296}$ or privacy for personal data provided to obtain a driver's license. ${ }^{297}$

This identification of federalism's intrinsic value with the ends to which it has sometimes been employed testifies to a double standard of another sort. Liberals, after all, enthusiastically embrace guarantees of many individual rights notwithstanding the fact that those rights often will protect individuals and activities they consider unattractive, even evil. In areas such as the freedom of expression guaranteed by the First Amendment, or the Fifth and Fourteenth Amendment rights of due process, liberals long have been eager to defend their enemies' rights in the name of a higher principle of broad applicability. Most famously, in 1977, the "liberal" American Civil Liberties Union defended the rights of uniformed neo-Nazis to march in

293. See, e.g., Jack Bass, The Flag Has Brought Anger-And Progress, WAsh. Post, Apr. $30,2000$, at B1 (observing that "[ $\mathrm{t}]$ he root issue behind South Carolina's ordinance of secession (which led to the Civil War) was 'the institution of slavery'; the 'states' rights' argument emerged only after the war was lost," and that the defenders of flying the Confederate flag over the South Carolina Statehouse nonetheless "have argued that it symbolizes 'heritage, not hate"'); see also William Edney, Editorial, Slavery Was Real Cause of Secession, AUGUSTA Chron. (Ga.), July 9, 2000, at A5 ("Much has been written about the Confederate flag and its heritage, the bravery of the Confederate soldier and states' rights.... The real issue [behind the secession of the Southern states] was slavery, or rather the opposition to slavery, on the part of some states.").

There is a certain irony about the state flag controversy, however. A favorite joke among our nationalist friends is that they favor state autonomy-as long as it extends only to choosing "state flags and state birds." After South Carolina, we seem to be down to birds.

294. See United States v. Lopez, 514 U.S. 549, 567-68 (1995) (holding unconstitutional a statute making it a federal offense to possess a gun in a school zone).

295. See Printz v. United States, 521 U.S. 898, 918-23 (1997) (deciding that portions of the Brady Act requiring state law enforcement to conduct background checks for fire-arm purchases were unconstitutional).

296. See United States v. Morrison, 529 U.S. 598, 613-19 (2000) (ruling that neither the Commerce Clause nor Section Five of the Fourteenth Amendment supported the federal civil remedy provided for in the Violence Against Women Act of 1994).

297. See Reno v. Condon, 528 U.S. 141, 148-50 (2000) (upholding the Driver's Privacy Protection Act, which regulates the disclosure of personal information from records of state motor vehicle departments, against a challenge based on Printz). 
Skokie, Illinois, a city with a large Jewish population, including many Holocaust survivors. ${ }^{298}$

Whether or not the underlying motivation is one of long-term self-interest ("there but for the grace of God go I"), the logic of sometimes protecting one's enemies in order to better protect one's own liberty is well understood by liberals in the context of individual rights. In the words of one ACLU official, "If the First Amendment required speech to be good or true or beautiful, who would decide? ... We protect free speech for racists to protect it for ourselves. ${ }^{299}$ In the area of federalism, however, the analogous big picture is less often kept in sight, and it is not clear why.

One reason may be that the associations of federalism with slavery and with the Old Court's assault on the New Deal are simply far more powerful than the association of the Free Speech Clause with repugnant but seemingly ineffectual speech. ${ }^{300}$ This would suggest that some sort of on-balance comparison is being made: the results of the judicial enforcement of federalism are more often detrimental to liberty than beneficial, while the results of the judicial enforcement of the Free Speech Clause show the opposite pattern. To be sure, we have not accompanied our account of how federalism enhances liberty by any such comparative judgment. Affirming Alfonso Lopez's freedom to carry a gun to school, for example, may (in the absence of a state law prohibiting the conduct) decrease liberty on balance by undermining the security of his classmates and interfering with their opportunity to obtain an education. Similarly, allowing state regulatory diversity on child labor may create a "race to the bottom" that makes it difficult for any state to enact arguably liberty-enhancing re-

298. See, e.g., Martin Finucane, ACLU to Represent Group that Advocates Sex Between Men and Boys, A.P. NEwswire, Aug. 31, 2000 (observing that the "ACLU has long accepted unpopular clients and despised causes, including Ku Klux Klansmen and neo-Nazis. In 1977, the ACLU defended the right of Nazis to march in Skokie, Illinois-home to many Holocaust survivors. Thousands of ACLU members quit and contributions plunged."); see also Collin v. Smith, 578 F.2d 1197 (7th Cir. 1978) (upholding the Nazis' right to march in Skokie on First Amendment grounds).

299. Barbara Bernstein, Letter to the Editor, NEwSDAY, Sept. 21, 1999, at A41. The author was executive director of the Nassau County chapter of New York Civil Liberties Union.

300. One might quarrel with the premise that proponents of hate speech, for example, are ineffectual. See, e.g., Mari J. Matsuda, Public Response to Racist Speech: Considering the Victim's Story, 87 MICH. L. REV. 2320, 2320-23 (1989) (detailing the serious harms resulting from racist speech). It would be far more honest, in our view, to recognize that we sometimes pay a price for negative rights in both the individual and state contexts. 
strictions. ${ }^{301}$ We do not argue, in other words, that federalism always will enhance liberty.

We doubt, however, that such on-balance judgments are generally made about the individual rights that courts routinely and rigorously enforce. No empirical study that we know of has compared the liberty costs of free speech enforcement-to victims of hate speech, libel, or violence arguably prompted by pornography, for instance, or to the integrity of a political system that cannot regulate campaign expenditures-to its pro-liberty benefits. ${ }^{302} \mathrm{We}$ do not suggest that such a study should or could be made; rather, we insist only that federalism's relationship to liberty should be judged in the same way and by the same standards that we use to judge individual rights like free speech. It is puzzling why we so often fail to do this, particularly when so many beneficiaries of First Amendment protection are proponents of precisely the same forms of racial hatred that federalism stands accused of sheltering. ${ }^{303}$

We set this objection aside for the remainder of this Part, however, because we think that the normative judgments frequently made about federalism are untenable even if viewed in isolation from comparisons with other constitutional principles. In the next section, we consider the association of federalism with racial apartheid. We then turn, in the final two sections, to predictive judgments about the political valence of federalism in national politics and the impact of uniform national rules in contemporary federalism cases.

\section{B. Federalism and Race}

The notion of "states' rights" today continues to suffer mightily under the weight of its association with a particularly tragic period in American history. To many, it stands for an anachronistic (and im-

301. See Hammer v. Dagenhart, 247 U.S. 251, 273 (1918) (considering but rejecting such an argument). These tradeoffs do, of course, rely on an expanded notion of "liberty" that encompasses something beyond mere freedom from constraint. We are not, however, inclined to quibble on this point.

302. The threats against which free speech enforcement guards us may be just as far-fetched as those that federalism enforcement seeks to prevent. After all, the government does not generally attempt to suppress the "pure" political speech that is generally thought to lie at the heart of the First Amendment, just as the federal government has not generally tried to abolish the independent existence of the states.

303. Indeed, efforts by states and localities to protect racial minorities against proponents of racial hatred have been struck down in the name of uniform national norms of free speech. See, e.g., R.A.V. v. City of St. Paul, 505 U.S. 377, 391-96 (1992) (invalidating a local ordinance prohibiting cross burning that had been upheld by a state supreme court). 
moral) preference for the race-based denial of essential individual rights that required the Civil War and much federal law to remedy. Professor Kreimer writes, for example, "In my formative years as a lawyer and legal scholar, during the late 1960s and 1970s, [federalism] was regularly invoked as a bulwark against federal efforts to prevent racial oppression, political persecution, and police misconduct." ${ }^{304}$ Thoughtful arguments in favor of the recognition and enforcement of states' rights therefore often are viewed as thinly veiled pleas for a return to the race-based inequality of the antebellum or Jim Crow South. ${ }^{305}$

It is indeed the case that federal laws-both constitutional amendments $^{306}$ and civil rights legislation ${ }^{307}$ - have played a crucial role in mitigating, if not eliminating, much discrimination against racial minorities since 1865. And much of that discrimination was explicitly sanctioned by various states' laws. ${ }^{308} \mathrm{We}$ are not quite ready to lay all the blame for slavery and segregation at the door of states' rights, however. As Earl Maltz recounts, the relationship between racial issues and federalism in the antebellum period does not reflect the simple dynamic that we find in the twentieth century. ${ }^{309}$ We already have discussed Prigg v. Pennsylvania ${ }^{310}$ in which Justice Story's strong endorsement of federal supremacy on the fugitive slave issue at least arguably had the effect of thwarting state efforts to protect black Americans. ${ }^{311}$

304. Kreimer, supra note 217, at 67.

305. See, e.g., John Mintz, A Battle Cry from Interior Nominee, WASH. Post, Jan. 11, 2001, at A1 (describing attacks on President George W. Bush's nominee for Secretary of the Interior, Gale Norton, that depicted her as racially insensitive for invoking states' rights).

306. U.S. CONST. amends. XIII, XIV, XV.

307. See, e.g., Civil Rights Act of 1964, Pub. L. No. 88-352, 78 Stat. 241 (codified as amended at 42 U.S.C. 2000 a et seq. (1994)).

308. E.g., Charles L. Black, Jr., The Lawfulness of the Segregation Decisions, 69 YALE L.J. 421, 424-27 (1960) (describing the state-sanctioned regime of Jim Crow segregation in the South).

309. Maltz, supra note 209, at 466.

310. 41 U.S. 539 (1842).

311. See supra notes 208-19 and accompanying text; Holden-Smith, supra note 209, at 1135 (observing that Prigg "was grounded in the expansive notion of implied [federal] powers" and "a mistrust of state legislatures and state courts that is also evident in [Story's] nationalistic opinions"); Maltz, supra note 209, at 475 (noting that "Story's opinion in Prigg rested almost entirely on the doctrine of federal supremacy"). We say "arguably" because some-including Justice Story himself-have contended that the decision actually helped slaves, either by affirming that slavery was entirely a creation of state law (Justice Story's own theory) or by holding that the federal government could not force the states to enforce the fugitive slave laws, thereby opening the way to state nullification. See Finkelman, supra note 209, at 658-62 (dis- 
The Court's infamous decision in the Dred Scott case ${ }^{312}$ also is difficult to square with the notion that federalism has a reliable valence on racial issues. As Professor Maltz demonstrates, the relationship of state autonomy to slavery in Dred Scott is quite complex. ${ }^{313}$ To take one of several possible examples, ${ }^{314}$ the Court's holding that Congress lacked power to forbid slavery in the territories seemed to restrict the authority of the federal government. ${ }^{315}$ That holding rested, however, on the idea that slaves were "property" protected by the federal Constitution. ${ }^{316}$ "If in fact slaves were defined as property for constitutional purposes," Professor Maltz argues, "then the [Privileges and Immunities Clause of Article IV] arguably imposed a duty on the free states to allow at least a limited extension of slavery into the areas under their control." ${ }^{, 177}$ The result was that

the pro-slavery argument on the territorial issue in Dred Scott suggested (at least by implication) a rather startling reversal of the normal constitutional structure of federalism. The federal government was to yield to state policy on slavery in the territories-land over which federal supremacy would normally be complete. By contrast, in the free states, national standards would constrain state

cussing these arguments). Other scholars have identified serious reasons to be skeptical of these attempts to redeem Justice Story's opinion. Professor Finkelman, for example, concludes that "Story's main concern in Prigg was to strengthen federal power at the expense of the states, in disregard of the rights of northern free blacks. The fact that some northern courts and legislatures were able to apply Prigg to produce anti-slavery results is accidental." Id. at 658; see also Holden-Smith, supra note 209, at 1136-38 (noting that it is unlikely that Justice Story intended such results, in that he was one of the chief architects of the 1850 Fugitive Slave Act). In any event, this sort of debate simply reinforces our basic argument that the relationship between federalism and race is more complex than many are willing to acknowledge.

312. Scott v. Sandford, 60 U.S. (19 How.) 393 (1857).

313. Maltz, supra note 209, at 480-94.

314. See also id., at 482-86 (arguing that Chief Justice Taney's position that states could not define citizenship for themselves actually maximized the freedom of slave states to restrict the rights of free blacks in disregard of their rights in their home states).

315. See id. at 488 :

On the issue of slavery in the territories itself, [Scott $]$ enhanced state autonomy at the expense of national supremacy. States were to define the rights of their citizens in the slaves that they brought with them to the territories; the only role of the federal government was to enforce those state-created rights.

316. Scott, 60 U.S. (19 How.) at 451.

317. Maltz, supra note 209, at 488. As Akhil Amar has observed, "[t]he only thing standing between Dred Scott's logic and the utter nationalization of slavery ... was a technical case called Barron v. Baltimore." Amar, supra note 203, at 22. 
policy determining the legal status of individuals within the territorial authority of the state governments. ${ }^{318}$

There are, of course, many readings of Dred Scott and it is not our purpose to definitively endorse any of them. Our point is simply that Dred Scott was hardly the straightforward endorsement of states' rights that some have suggested, ${ }^{319}$ rather, the case is emblematic of the complex and contingent relationship between federalism and race in our history.

A final antebellum example is considerably more straightforward. Ableman v. Booth ${ }^{320}$ involved a federal prosecution under the 1850 Fugitive Slave Act for rescuing a fugitive slave who had been recaptured by his master in Wisconsin. Believing the federal Act to be unconstitutional, the Wisconsin Supreme Court twice tried to intervene by issuing writs of habeas corpus requiring Booth's release. The United States Supreme Court, however, unanimously held that the state court had no authority to require the release of a person in federal custody. ${ }^{321}$ Booth reflects not only the proslavery tendency of some federal substantive law during the antebellum period, but also the fact that federal courts were relatively hostile to antislavery forces during this period. ${ }^{322}$

Prigg and Booth both arose because antislavery forces were more powerful at the local than the national level; Dred Scott's recognition of a uniform federal right to property in slaves was threatening to state autonomy for the same reason. Indeed, the history of the Abolitionist movement could be viewed as a case study of how opposition to tyrannical national policies can develop first at the state

318. Maltz, supra note 209, at 489.

319. E.g., Larry D. Kramer, But When Exactly Was Judicially-Enforced Federalism "Born" in the First Place?, 22 HARV. J.L. \& PUB. POL'Y 123, 131 (1998) (contending that Dred Scott represented an early and rare example of judicially enforced federalism); Gene R. Nichol, Justice Scalia and the Printz Case: The Trials of an Occasional Originalist, 70 U. COLO. L. REV. 953, 954-55 (1999) (asserting that Dred Scott and other attempts "to resurrect ... principles of judicial federalism" have been looked on disfavorably from a historical perspective).

320. 62 U.S. (21 How.) 506 (1858).

321. Id. at $514-15$.

322. See Maltz, supra note 209, at 494 ("After Prigg and Dred Scott, it became clear that the federal courts would be the allies of the pro-slavery forces. Anti-slavery activists, by contrast, retained powerful influence in the organs of state government."); Suzanna Sherry, Independent Judges and Independent Justice, 61 LAW \& CONTEMP. PROBS. 15, 18 (Summer 1998) (noting that several northern state courts "behaved more courageously than the life-tenured judges of the United States Supreme Court" on slavery issues during the antebellum period). 
level, then achieve sufficient influence to change national policy. ${ }^{323} \mathrm{Al}-$ though no one should forget that states' rights also sheltered slavery in the South, it is far from obvious what path our nation's history might have taken had the Founding Generation established a unitary government instead of a federal one. Four of our first five presidents, after all, were slaveholders from Virginia. ${ }^{32}$

In any event, federalism's current bad odor is a historically contingent function of the uses to which federalism's advocates sometimes have put state autonomy-specifically, as a sanctuary for slavery and segregation. To leap from this history to a condemnation of federalism in general is to misunderstand that states' rights are a form of negative freedom. As we explained in the previous Section, the freedom of local political communities to choose their own visions of the good society, like any other form of "diversity," predictably produces a mixed bag of results. ${ }^{325}$ We therefore should not be surprised that the vision of the "good" that some communities choose to pursue is, well, bad. Anyone who (a) believes that diversity is an important value but (b) is not a complete moral skeptic-i.e., believes that at least some moral questions have "right answers"-must live with these sorts of contradictions. Diversity always entails the freedom to make wrong choices.

The way that American society has dealt with this tension is to place certain fundamental values off limits to diversity by enshrining them in the Constitution itself. Society does not, for example, allow local communities to organize themselves along aristocratic lines by

323. See, e.g., J. Morgan Kousser, "The Supremacy of Equal Rights": The Struggle Against Racial Discrimination in Antebellum Massachusetts and the Foundations of the Fourteenth Amendment, 82 Nw. U. L. REV. 941 (1988) (describing the efforts of abolitionists to institute reform at the state level); Michael Kent Curtis, The Curious History of Attempts to Suppress Antislavery Speech, Press, and Petition in 1835-37, 89 Nw. U. L. REV. 785, 787 (1995) (discussing efforts to suppress abolitionist speech in the antebellum years, concluding that the existence of state-by-state diversity on the suppression issue "meant that discussion of the legitimacy of slavery continued").

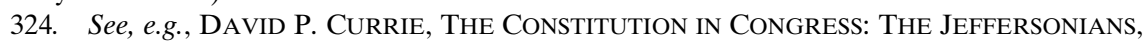
1801-1829, at xi (2001) (observing that "[f]or twenty-four years Virginia Republicans inhabited the President's House, and their party was dominant in Congress"). One must add George Washington, of course, to Presidents Jefferson, Madison, and Monroe in the Jeffersonian period discussed by Professor Currie. These men, of course, had complicated-sometimes torturedattitudes toward slavery. Our point is simply that attempting to imagine the likely fate of slavery in a unitary republic involves a huge counterfactual with many complex variables. See, e.g., Maltz, supra note 209, at 467 (observing that a uniform national position on slavery was politically impossible in 1787). It is not obvious that things would have worked out better for African Americans without federalism.

325. See supra Part IV.A.2. 
granting titles of nobility. ${ }^{326}$ So, too, has society dealt with the past failure of some states adequately to protect individual freedom and equality: the Thirteenth, Fourteenth, and Fifteenth Amendments go directly to the issue of racial equality, while the gradual incorporation of the Bill of Rights ensures that other freedoms society has come to regard as basic are respected in all American jurisdictions. ${ }^{327}$ While the actual realization of all these values no doubt remains incomplete, states' rights are no longer a barrier to these constitutional values. ${ }^{328}$

This point is worth underlining: constitutional principles of state autonomy no longer even arguably protect state authority to engage in racial discrimination or any other activity that violates federal constitutional rights. ${ }^{329}$ As Douglas Laycock observes, "[w]e may view sister-state law as seriously unjust on particular points, but these disputes are minor variations within substantially similar legal systems. Slavery was the great uncompromisable exception, but slavery has been uniformly abolished." ${ }^{330}$ Opponents of the states sometimes talk as if they have forgotten the Fourteenth Amendment and the Supremacy Clause. Frankly, it is easier to advocate federalism in a world with the Fourteenth Amendment and its associated incorporation

326. U.S. CONST. art. I, § 10 .

327. See, e.g., Duncan v. Louisiana, 391 U.S. 145, 148 (1968) (stating that the Due Process Clause of the Fourteenth Amendment incorporates against the states those "fundamental principles of liberty and justice which lie at the base of all our civil and political institutions"); Palko v. Connecticut, 302 U.S. 319, 325 (1937) (stating that the incorporation doctrine precludes the states from violating "principle[s] of justice so rooted in the traditions and conscience of our people as to be ranked as fundamental"); GEOFFREY R. STONE ET AL., CONSTITUTIONAL LAW 811 (3d ed. 1996) (observing that "[t]he only provisions of the first eight amendments that have not been incorporated are the second and third amendments, the fifth amendment's requirement of grand jury indictment, and the seventh amendment").

328. To say this is not to argue that federalism concerns should never enter into the initial choice of whether to constitutionalize a particular value. See infra Part IV.D.1. Federalism concerns also may enter into the question of remedies for particular constitutional violations. See, e.g., O'Shea v. Littleton, 414 U.S. 488, 499-502 (1974) (refusing to issue an injunction against prospective discriminatory criminal prosecutions or sentences); Younger v. Harris, 401 U.S. 37, 43-52 (1971) (holding that the federal courts ordinarily may not enjoin a pending state criminal proceeding). But these remedial barriers would remain even if the courts did not enforce substantive limits on Congress's power.

329. That does not mean that the Fourteenth Amendment repealed constitutional federalism in areas not addressed by its text. See supra note 269.

330. Laycock, supra note 12 , at 260 . We would add that any continuing controversy over slavery's legacy of racial discrimination also is dominated by norms whose national character is not in dispute. As a result of the nationalization of this issue, Professor Laycock contends that "it would be a serious error to design choice-of-law rules around slavery . . . instead of around the thousands of routine conflicts between ordinary laws." Id. at 260. We think it would be an even worse error to design federalism doctrine around slavery and segregation rather than around the many areas that remain constitutionally open to state-by-state diversity. 
doctrine firmly in place - that is, where the diversity of choices reserved to states is limited by a "floor" of basic, federal constitutional guarantees - than it might be were the law otherwise. But that is the world in which Americans live, and opponents as well as supporters of federalism ought to recognize it.

Given that federal constitutional law now places racial equality and most basic individual rights off limits to state-by-state diversity, the normative case against federalism becomes harder to articulate. Although this case is rarely stated forthrightly, it seems to us typically to encompass two elements: First, the actual normative benefits of federalism are said to be minimal, so that any risk that federalism will slight appealing normative values should weigh very heavily. ${ }^{331} \mathrm{We}$ already have discussed the benefits of federalism in protecting liberty; ${ }^{332}$ other benefits of state-by-state diversity-such as facilitating regulatory competition or promoting civic participation-are the subject of a vast literature that we need not reproduce here. ${ }^{333}$ The second element involves the claim that federalism is likely to undermine normatively attractive values that-unlike racial equality, freedom of expression, and the like-have not yet been constitutionalized. This claim rests on at least two important assumptions: that there are "right answers" to many questions of social policy, and that politicians at the national level are more likely to discern and to favor those answers than politicians at the state level. We question both assumptions in the next Section.

\section{States' Rights, Nationalism, and Liberal Ideology}

We argued in the previous Section that in the area of race, where federalism has had its most tragic costs, a hard-won national consensus has replaced state-by-state diversity with uniform constitutional norms of equality. This is not to say, of course, that those norms have been realized perfectly-only that opposition to them no longer rests on a plausible argument from states' rights. ${ }^{334}$ Federalism continues to

331. See, e.g., Rubin \& Feeley, supra note 93, at 909. Professor Rubin made the point even more starkly in a subsequent article. See Edward L. Rubin, The Fundamentality and Irrelevance of Federalism, 13 GA. ST. U. L. REV. 1009, 1029-30, 1041-61 (1997); see also Edward L. Rubin, Puppy Federalism and the Blessings of America, 574 AnNAls AM. ACAD. POL. \& Soc. SCI. 37, 45-47 (2001) [hereinafter Rubin, Puppy Federalism].

332. See supra Part IV.A.1.

333. See, e.g., SHAPIRO, supra note 223, at 76-106; Merritt, supra note 15, at 3-10; McConnell, supra note 217 , at $1491-1511$.

334. Indeed, from the standpoint of liberals who favor affirmative action, one of the greatest threats to racial equality today may come from the attempt to create a uniform national norm of 
matter, however, with respect to a wide range of issues that have not been constitutionalized. The claim of federalism's critics is that on these issues-which may range from environmental protection to employment discrimination to welfare administration-state-by-state diversity is a bad thing. ${ }^{335}$

A couple of observations about this claim are in order at the outset. First, it presupposes that there are right answers to many questions of social policy and law, notwithstanding the belief of others that these very same issues are ones on which reasonable people might disagree. If one is sure that one knows the "right answer" on issues such as abortion, affirmative action, the death penalty, and same-sex marriage, for example, then the federal government is obviously the most efficient provider of legislation to impose those "right answers" on the rest of the country.

Second, in the absence of consensus, imposition of a uniform national solution almost always will satisfy fewer people, and therefore may result in decreased aggregate social welfare, than would allowing for state-by-state variation. As Michael McConnell demonstrates, state-by-state diversity generally will allow government to accommodate the preferences of a greater proportion of the electorate, as long as those preferences are unequally distributed geographically. ${ }^{336}$ And, as one of us has explained previously, this also is likely to mean that the imposition of national uniformity in the absence of consensus will

color blindness that would preempt state autonomy to implement race-conscious remedies for past discrimination. See, e.g., Hopwood v. Texas, 78 F.3d 932, 944-46 (5th Cir. 1996) (holding that the University of Texas School of Law's affirmative action admissions program violated the Equal Protection Clause).

335. See supra note 267. Professor Rubin suggests a somewhat different answer in two other articles, in which he contends, inter alia, that there are no meaningful differences among the American states. Rubin, Puppy Federalism, supra note 331, at 45-46 (asserting that the United States "is a socially homogenized" nation in which "[r]egional differences between different parts of the nation are minimal, and those that exist are based on inevitable economic variations, rather than any historical or cultural distinctions"); Rubin \& Feeley, supra note 93, at 909 (contending that "federalism does not secure community because our real community is a national one"). We do not have space to conclusively refute Professor Rubin's claim here; instead, we simply would invite him to come live in Texas for six months.

336. McConnell, supra note 217 , at 1494 . Whether the accommodation of more people's preferences actually increases social welfare, of course, depends to some extent on how both preferences and welfare are measured and, in the end, on what the preferences are for. A majority preference in a given jurisdiction for slavery, for instance, would raise grave difficulties for any measure of welfare based solely on satisfying the preferences of the greatest number. Our claim here is simply that complications like this often are not present and that state-by-state diversity often will increase welfare. A categorical rule against judicial enforcement of federalism would make normative sense only if we had strong evidence that federalism generally decreases welfare. That showing has not been made. 
reduce aggregate social welfare relative to permitting state-by-state diversity. ${ }^{337}$ We set these observations aside for this Article, however. What fascinates us is the belief that, assuming there is a right answer and that it is appropriate to impose it throughout the nation whatever costs such a mandate might involve, federal politicians generally will be willing to do so.

This view of the federal government as the inevitable purveyor and protector of "good" social policies is an especially easy one for today's liberals to hold because of the Democratic party's dominance of Congress from 1955 to 1995 . The Democrats had a majority of the House for that entire period and had a majority of the Senate for all but six of those years. ${ }^{338}$ Although the November 1994 election yielded a Republican majority in the House that exists to this day, ${ }^{339}$ and a Republican majority in the Senate that existed until Vermont Senator Jim Jeffords's defection in May 2001, ${ }^{340}$ liberals may view the past six years as nothing more than an unfortunate (and surely shortlived) aberration. Because recent events are more salient than those of long ago, it may be easy for liberals to forget that the Republican party, too, has had periods when it has controlled both houses of Congress for several decades. ${ }^{341}$

We think it is extremely risky to make structural decisions about how power should be allocated based on predictions that any particular group will continue to dominate a particular portion of the

337. Baker, Conditional Federal Spending, supra note 161, at 1947-51, 1970-72.

338. Bureau of the Census, U.S. DeP'T of Commerce, Historical Statistics of THE United States, COlONIAL times to 1970, pt. 2, at Y204-10 (1975) [hereinafter Historical STATistics] (1955-70 statistics); BuREAU OF THE CENSUS, U.S. DEP'T OF Commerce, Statistical Abstract of the United States, 2000, at 281 tbl.460 (120th ed. 2000) [hereinafter STATISTICAL ABSTRACT] (1971-99 statistics). The Republican party had a majority in the Senate from 1981-87. Id.

339. Statistical AbSTRACt, supra note 338, at 281 tbl.460; see also, e.g., Editorial, Protest Vote: An Angry Electorate Hands the Republicans a Landslide, PITTSBURGH Post-GAZETTE, Nov. 10, 1994, at C2.

340. StAtistical AbSTRACt, supra note 338, at 281 tbl.460; Katharine Q. Seelye with Adam Clymer, Balance of Power: The Power Shift; Senate Republicans Step Out and Democrats Jump In, N.Y. TIMES, May 25, 2001, at A1 (observing that Jeffords's departure from the Republican party to become an Independent "tips the fragile 50-50 power balance in the Senate to a 50-49 Democratic edge").

341. Historical Statistics, supra note 338, at Y204-10; see also, e.g., Adam Clymer, Theorists Look at '94 Voting: Was It Major or Minor Trend?, N.Y. TIMES, Sept. 4, 1995, at A8 (noting that the Republican victory of 1894 ushered in a third of a century of Republican congressional dominance); Michael Wines, Donkey Drop; Bradley's Exit Is Not Just the Democrats' Problem, N.Y. TIMES, Aug. 20, 1995, at $\S 4$, at 1 ("Republicans had ruled politics for 30 years, and Democrats were a husk of a party, too feeble even to repudiate the Ku Klux Klan, only eight years before Franklin D. Roosevelt founded a political dynasty in 1932.”). 
government for long. Our history simply provides too many examples of shifting political alignments-among the branches of the federal government, between the federal and state levels of government, and even within the major political parties. ${ }^{342}$ Edward Purcell's recent study of the relationship between Progressive politics and the federal judicial power, for example, reveals how dramatically the affinities of particular political ideologies for different governmental institutions can change over time..$^{343}$ In the early part of the last century, Progressives like Louis Brandeis tended to favor decentralized federalism and legislative supremacy as the most reliable approach to combating the centralized power of huge national corporations, ${ }^{344}$ "conservatives" ${ }^{345}$ allied with big business, on the other hand, tended to favor the national government over the states and the federal courts over Congress as the institutions most likely to realize their political, economic, and social goals. ${ }^{346}$ Debates over the New Deal, however, tended to find "liberals" espousing centralized national regulation while shifting their emphasis from legislative to executive supremacy. ${ }^{347}$ By the Warren Court era, affinities had shifted yet again, with liberals embracing judicial supremacy as a means for imposing uniform constitutional values, while conservatives who had become states' righters during the New Deal debate now discovered the virtues of legislatures over courts. ${ }^{348}$

342. With respect to the political parties, it is worth noting that the decades of Democratic dominance of Congress discussed in the text mask a considerably more complicated picture. Although the Democratic party was at some times and on some issues the party of progressive reform, it also was the party of southern apartheid for much of that period. See, e.g., William E. Forbath, The New Deal Constitution in Exile, 51 DukE L.J. 165, 203-17 (2001) (discussing the role of southern Democrats in derailing President Franklin D. Roosevelt's push for federal welfare rights).

343. Edward A. Purcell, Jr., Brandeis and the Progressive Constitution: ERIE, the Judicial Power, and the Politics of the Federal Courts in TwentiethCENTURY AMERICA 23-26 (2000).

344. Id. at $134-35$.

345. We use the term "conservative" here in the admittedly vague political sense in which that term is popularly understood, while recognizing that it may have quite different meanings in other contexts. See Young, Rediscovering Conservatism, supra note 80, at 659-86 (illustrating the differences between modern conservative judicial theory and the classic Burkean model of conservatism).

346. PURCELL, supra note 343, at 69.

347. Id. at 38 .

348. Id. at 199. 
The Rehnquist Court has, of course, scrambled these alignments once again. ${ }^{349}$ As the federal courts have become more conservative politically, liberals increasingly have criticized the judiciary; some prominent academics on the left have even begun to question the institution of judicial review. ${ }^{350}$ We have yet to see much in the way of a similar shift on the state-federal axis, however, despite the Republican party's current dominance of the federal executive and half the Congress. Perhaps, again, liberals tend to see that dominance as aberrational and simply hope for a prompt restoration of Democratic party dominance in 2002 or 2004 .

That perspective, however, neglects the long-term instability of institutional affinities that Professor Purcell and others note. Given the unpredictability of national elections over the long term, the rational and risk-averse position, even for those who believe there are "right answers" to important questions of social policy, is to favor states' rights. If some measure of state autonomy exists, liberals and conservatives alike can expect there to be at least one state with laws that will reflect their views on certain social issues even when both houses of Congress are controlled by the party they oppose. Liberals, however, rarely seem to appreciate that judicial enforcement of states' rights provides them this long-term benefit.

If antifederalism liberals are too optimistic about the central government, they are too pessimistic about the states. There always have been areas of social policy in which certain states have been more "progressive," more "liberal," than the federal government. As Professor Purcell notes, for example, "state legislatures took the lead"-albeit "[e]rratically and unevenly"-in addressing the problems of industrialism that had become evident by the end of the nineteenth century. ${ }^{351}$ During this same period, federal law-particularly the "general common law" articulated in the federal courts as well as federal constitutional doctrine under the Due Process Clause-was most often a tool used by big business to resist these progressive state impulses. $^{352}$

349. Id. at $285-86$.

350. E.g., MARK R. TUSHNET, TAKING THE CONSTITUTION AWAY From THE COURTS 12976 (1999); SANFORD LEVINSON, CONSTITUTIONAL FAITH 46-50 (1988) (questioning the Justices' monopoly on constitutional interpretation).

351. PURCELL, supra note 343, at 12.

352. E.g., Tony Freyer, Harmony \& Dissonance: The SWIFT and ERIE Cases in AMERICAN FEDERALISM 94-95 (1981); PURCELL, supra note 343, at 14-16, 51-56, 67. 
Nor do we lack for more contemporary examples. One would hope, for example, that environmentalists around the globe arise each morning and give thanks for California, which has adopted stringent automobile emissions standards that are unlikely to have passed at the federal level, but that have influenced automakers around the world to build cleaner, more fuel-efficient cars. ${ }^{353}$ Today, moreover, many states provide constitutional and statutory protection against various forms of discrimination on the basis of sexual orientation while federal law does not. ${ }^{354}$ Other areas in which some states in recent years have been more "progressive" than the federal government include: the right to use marijuana for medical purposes, ${ }^{355}$ welfare rights, ${ }^{356}$ and freedom of expression. ${ }^{357}$

By ignoring the benefits of federalism, nationalists increase the risk that each of these areas of state law will fall victim to federal ho-

353. Replacing Gas with a Gas, ECONOMIST, July 21, 2001, at 1 (reporting that because of the "pressing need to produce vehicles that can comply with the exacting emissions standards of California ... several of the world's car makers—notably Ford, DaimlerChrysler, and Hondaare studying fuel cells" that would use hydrogen and oxygen to power automobiles).

354. Compare, e.g., CONN. GEN. STAT. AnN. § 46a-81a-41a-81r (West 1995) (prohibiting discrimination on the basis of sexual orientation in a variety of settings), and HAW. REV. STAT. ANN. § 368-1 (Michie 1999) (same), with 42 U.S.C. § 3604 (1994) (prohibiting housing discrimination only on the basis of "race, color, religion, sex, familial status, or national origin"- the reference to "familial status" referring not to sexual orientation but to "one or more individuals (who have not attained the age of 18 years) being domiciled with (1) a parent or another person having legal custody of such individual or individuals; or (2) the designee of such parent or other person having such custody"). Compare also CAL. LAB. CODE $§ 1102.1$ (West 1989 \& Supp. 2001) (prohibiting employment discrimination on the basis of sexual orientation), and HAW. REV. STAT. ANN. § 368-1 (Michie 1999) (same), with 42 U.S.C. § 2000e-2 (1994) (prohibiting employment discrimination only on the basis of "race, color, religion, sex, or national origin"), and 29 U.S.C. $\$ 623$ (1994) (prohibiting employment discrimination on the basis of age).

355. Compare, e.g., CAL. Health \& SAFETy CODE $§ 11362.5$ (West Supp. 2001) (creating an exception to California laws prohibiting possession and cultivation of marijuana for seriously ill persons who use it for medical purposes), and ME. REV. STAT. ANN. tit. 22 § 2383-B (West Supp. 2000) (making lawful the possession of marijuana for medical use by individuals with certain serious diseases), with 21 U.S.C. \$§ 801-904 (1994) (prohibiting the manufacture and distribution of various drugs, including marijuana), and United States v. Oakland Cannabis Buyers' Coop., 532 U.S. 483, 121 S. Ct. 1711, 1715 (2001) (holding there to be no "medical necessity exception" to the Controlled Substances Act).

356. See, e.g., N.Y. CONST. art. XVII, $\S 1$ (providing that " $[\mathrm{t}]$ he aid, care and support of the needy are public concerns and shall be provided by the state and by such of its subdivisions, and in such manner and by such means, as the legislature may from time to time determine"); Helen Hershkoff, Welfare Devolution and State Constitutions, 67 FORD. L. REV. 1403, 1408-16 (1999) (discussing the history and judicial interpretation of Article XVII of the New York Constitution).

357. See, e.g., N.J. Coalition Against War in the Middle East v. J.M.B Realty Corp., 650 A.2d 757, 760 (N.J. 1994) (stating that Article I of the New Jersey Constitution confers on "citizens an affirmative right of free speech that [is] protected not only from governmental restraint - the extent of First Amendment protection—but from the restraint of private property owners as well"). 
mogenization by a less "progressive" Congress, whether through direct regulation, conditional federal spending, or preemption. The judicial enforcement of states' rights, in contrast, at least sometimes would require congressional supporters of homogenization in these areas to secure a federal constitutional amendment to that effect. For outlier states, the advantage of that requirement is clear: it will usually be easier to assemble the coalition of thirteen states necessary to block an amendment to the United States Constitution ${ }^{358}$ than to garner the simple majority in either the House or Senate necessary to block a congressional enactment.

Of course, increased diversity among the states is not always a good thing. Federal homogenizing legislation may sometimes increase aggregate social welfare by impeding welfare-reducing interstate races to the bottom, ${ }^{359}$ or by reducing the costs that disuniformities may impose on corporations and individuals seeking to act in more than one state. ${ }^{360}$ These observations, however, do not lead inexorably to the conclusion that judicial enforcement of states' rights is either unnecessary or ultimately aggregate-welfare reducing.

First, as we noted previously, unfettered federal legislation is not needed to rid states of their most pernicious laws: our federal and state constitutions unambiguously prohibit their enactment and enforcement. ${ }^{361}$ State laws that violate no federal constitutional provi-

358. Article $\mathrm{V}$ of the United States Constitution requires the consent of two-thirds of both houses of Congress to propose amendments and the subsequent consent, by the legislature or by a convention, of three-fourths of the states for ratification. U.S. CONST. art. V. An amendment also can be proposed by a national convention called by Congress pursuant to "the Application" of the legislatures of two-thirds of the states. Id.

359. The most obvious examples are laws concerning environmental regulation and poverty relief. See supra note 224; see also, Baker, Conditional Federal Spending, supra note 161, at 1951 n.186 (discussing the "race to the bottom" in various contexts); Richard L. Revesz, Rehabilitating Interstate Competition: Rethinking the "Race-to-the-Bottom" Rationale for Federal Environmental Regulation, 67 N.Y.U. L. REV. 1210, 1210-11 (1992) (observing that "the race to the bottom has been invoked as an overarching reason to vest regulation that imposes costs on mobile capital at the federal rather than the state level, and has been cited as one of the bases for [federal environmental statutes and for] the New Deal") (footnotes omitted).

360. The costs imposed by such disuniformities are among the arguments frequently made in favor of the federal reform of tort law. See, e.g., Gary T. Schwartz, Considering the Proper Federal Role in American Tort Law, 38 ARIZ. L. REV. 917, 924-32 (1996) (discussing nonuniformity issues in products liability cases).

361. For examples of such provisions in the United States Constitution, see Baker, Conditional Federal Spending, supra note 161, at nn.194-200. For examples of such provisions in state constitutions, see $i d$. n.177. We would think this point almost too obvious to mention if it were not so often ignored. Harold Koh, for example, worries that if states were not bound by federalized customary international law rules or a federal treaty forbidding genocide, "the fifty states of the Union [would have] no domestic legal obligation" to refrain from committing genocide. Harold Hongju Koh, Is International Law Really State Law?, 111 HARV. L. REV. 1824, 1840 
sion but that nonetheless express a moral preference that some find reprehensible-for example, laws making the death penalty available for first-degree murder convictions, ${ }^{362}$ providing free abortions to indigent women, ${ }^{363}$ or providing legal recognition of same-sex marriages or "domestic partnerships" agreement within our society. And these are precisely the areas in which interstate diversity is most valuable and federal homogenization will therefore reduce aggregate social welfare most greatly.

Should our society reach a substantial consensus that interstate diversity in some area is no longer acceptable, we always can amend the Constitution to prohibit the practice agreed to be immoral. History offers many examples of our willingness and ability to amend the Constitution to reflect such shifts in our moral sensibilities: ${ }^{365}$ the Thirteenth Amendment's prohibition against slavery; ${ }^{366}$ the Fourteenth Amendment's guarantee to all persons of due process and equal protection of the laws, ${ }^{367}$ the Fifteenth Amendment's prohibition against

(1998). One would think, as Curt Bradley and Jack Goldsmith point out, that the federal and state constitutions also might have something to say about state action amounting to genocide. Curtis A. Bradley \& Jack L. Goldsmith, Federal Courts and the Incorporation of International Law, 111 HARV. L. REV. 2260, 2274 (1998).

362. E.g., ARIz. Rev. Stat. AnN. § 13-703 (West 2001); MD. AnN. Code art. 27, § 412(b) (1996); Tracy L. Snell, Capital Punishment 1999, Bureau OF Justice Statistics Bull. (United States Dep't of Justice), Dec. 2000, at 3 tbl.1 (listing capital offenses, if any, by state).

363. See, e.g., Right to Choose v. Byrne, 450 A.2d 925, 935, 938 (N.J. 1982) (deciding that under a New Jersey statute, N.J. STAT. ANN. § 30:4D-6.1 (West 1981), the state must provide funds for all medically necessary abortions); Doe v. Maher, 515 A.2d 134, 143-45 (Conn. Super. Ct. 1986) (reaching the same result under a Connecticut statute, CONN. GEN. STAT. ANN. § 17134b (West 1995) (renumbered as $§ 17 \mathrm{~b}-260$ ), and holding invalid a regulation that limited funding to those abortions necessary to save the life of the mother); Linda M. Vanzi, Freedom at Home: State Constitutions and Medicaid Funding for Abortions, 26 N.M. L. REV. 433, 441-51 (1996) (discussing state constitutional challenges to state statutes restricting public funding for abortions).

364. VT. STAT. ANN. tit. 15, § 1202 (Supp. 2000) (authorizing establishment of a "civil union" by individuals who are "of the same sex and therefore excluded from the marriage laws of this state" and who meet various other criteria); Carol Ness, Couples Flock to Vermont, the Only Legal Place to Get Hitched, S.F. EXAMINER, Aug. 7, 2000, at A1 (observing that of the first 263 couples whose civil unions had been registered with the Vermont Vital Records Office, 84 were from Vermont and 179 were from other states).

365. On occasion, however, the Constitution has proven surprisingly difficult to amend. Baker, Conditional Federal Spending, supra note 161, at 1950 n.182 (describing the failure to adopt the Equal Rights Amendment even though from 1972 to 1982 "a majority of Americans consistently told interviewers that they favored this Amendment to the Constitution" (quoting JAne J. MAnsbridge, Why We Lost THE ERA 1 (1986))); see also Lynn A. Baker, Constitutional Change and Direct Democracy, 66 U. COLO. L. REV. 143, 152-53 (1995) (discussing difficulties posed by supermajority requirements for constitutional amendments).

366. U.S. CONST. amend. XIII, § 1 (adopted 1865).

367. Id. amend. XIV, $\S 1$ (adopted 1868). 
race-based discrimination in voting rights, ${ }^{368}$ the Eighteenth Amendment's prohibition against the manufacture, sale, or transportation of intoxicating liquors within the United States; ${ }^{369}$ the Twenty-First Amendment's repeal of the Eighteenth Amendment; ${ }^{370}$ the Nineteenth Amendment's prohibition against gender-based discrimination in voting rights; ${ }^{371}$ and the Twenty-Sixth Amendment's guarantee of the right to vote to all citizens eighteen years of age or older. ${ }^{372}$ Other mechanisms, such as the Commission on Uniform State Laws or the American Law Institute's Restatement projects, may achieve substantial voluntary uniformity in state law without a constitutional amendment.

Second, liberals should recognize that imposition of a national solution-whether by federal statute or federal judicial recognition of a substantive constitutional right-prior to reaching social consensus may stifle important progressive impulses. We discuss two important contemporary examples in the next Section.

\section{Boy Scouts, Cigarettes, and the Curious Structure of Contemporary Federalism Cases}

Two important aspects of federalism in contemporary circumstances frequently are overlooked. The first is its role in mediating some of the tensions among different individual rights that exist in large part because of the Warren Court's expansion of rights and the post-New Deal rise of the administrative state. The second has to do with the contemporary relationship between federalism and economic regulation. We discuss each of these functions in turn.

1. Mediating the Conflict of Rights-the Boy Scouts Case. As we noted previously, one important area of state-by-state diversity has been the recognition, by some states but not others, of a state-law right to be free from discrimination on the basis of sexual orientation. ${ }^{373}$ The situation has illustrated many of the classic arguments for federalism: people have been able to accommodate their own preferences by voting with their feet, ${ }^{374}$ and the states with more progressive

368. Id. amend. XV, § 1 (adopted 1870).

369. Id. amend. XVIII, § 1 (adopted 1919).

370. Id. amend. XXI, §§ 1-2 (adopted 1933).

371. Id. amend. XIX, § 1 (adopted 1920).

372. Id. amend. XXVI, § 1 (adopted 1971).

373. See supra notes 206-07, 354 and accompanying text.

374. See supra note 288. 
rules have served as laboratories for assessing the benefits and costs of extending antidiscrimination laws in this way. ${ }^{375}$

In Boy Scouts of America v. Dale ${ }^{376}$ however, the Supreme Court struck down a New Jersey statute banning discrimination on the basis of sexual orientation in public accommodations. The broad holding of the case appears to be that private groups have a First Amendment right to engage in discrimination, so long as they are sufficiently articulate about their policy for a court to label it "expressive." ${ }^{377}$ That holding might appear to endanger important federal laws barring private discrimination based on race and gender. We suspect, however, that the Court may find a way to save those statutes, perhaps by recognizing a uniquely compelling government interest in combating those federally recognized sorts of discrimination.

If that is the way the cases play out, the Rehnquist Court effectively will have constitutionalized the law of private discrimination in much the same way that the Warren Court constitutionalized the law of criminal procedure. ${ }^{378}$ Federal law will set both a floor for such legislation (through the 1964 Civil Rights Act) ${ }^{379}$ and a ceiling (through this new-found federal right (not) to associate) with precious little room for state variation in between. We all will be deprived of the benefits both of state experimentation and of allowing persons with different preferences to live under different legal regimes. And liberals will have lost an important battle in the culture wars. ${ }^{380}$

375. E.g., New State Ice Co. v. Liebmann, 285 U.S. 262, 311 (1932) (Brandeis, J., dissenting) ("It is one of the happy incidents of the federal system that a single courageous State may, if its citizens choose, serve as a laboratory; and try novel social and economic experiments without risk to the rest of the country.").

376. 530 U.S. $640,661(2000)$.

377. Id. at $640-41$.

378. See, e.g., Chapman v. California, 386 U.S. 18, $56-57$ (1967) (Harlan, J., dissenting) (complaining that the Court's recognition of a uniform federal constitutional standard for harmless error preempted diverse state approaches to the problem); Miranda v. Arizona, 384 U.S. 436, 515 (1966) (Harlan, J., dissenting) (arguing that "the Court has not and cannot make the powerful showing that its new rules are plainly desirable in the context of our society, something which is surely demanded before those rules are engrafted onto the Constitution and imposed on every state and county in the land."). Interestingly, the elder Justice Harlan made a similar argument in dissent in Lochner itself. See infra note 393 and accompanying text.

379. Pub. L. No. 88-352, 78 Stat. 241 (codified as amended at 42 U.S.C. § 2000a (1994)).

380. We do not wish to suggest, however, that concern about the rights of gays and lesbians is or should be confined to liberals. See, e.g., Dale Carpenter, A Conservative Defense of Romer v. Evans, 76 IND. L.J. 403, 404 (2001); see also Lynn A. Baker, The Missing Pages of the Majority Opinion in Romer v. Evans, 68 U. COLO. L. REV. 387, 389 (1997) (arguing that the majority in Romer "reached the right result, but for reasons that it articulated only partially or not at all"). 
The fact that Boy Scouts was decided under the First Amendment should not obscure its federalism ramifications. During the Warren Court years, Justice Harlan's dissents routinely invoked federalism as a reason not to recognize new constitutional rights. ${ }^{381}$ Decisions like Miranda, for example, replaced state-by-state variation and experimentation on the proper handling of police interrogations with a uniform federal rule ostensibly derived from the Constitution. ${ }^{382}$ This is not to say that those decisions were wrong. The rights invoked in Miranda and similar cases are important ones, and it may have been appropriate to place them off limits to state-by-state diversity.

Decisions like Boy Scouts, however, involve a tension between two individual rights - the right of association and the right to equality ${ }^{383}$ - each of constitutional significance. To the extent that the Court's interpretation of the First Amendment in Boy Scouts hardly was compelled, it might have been wise for the Court at least to acknowledge that it considered the benefits as well as the costs of stateby-state diversity in this area in reaching its decision. Certainly, Boy Scouts provides a vivid illustration of the potential of uniform federal rules to impede liberal goals.

2. Regulatory Federalism and Preemption: Who's Lochner Now? Finally, it is important to recognize the changing role that federalism is playing in some of our longstanding debates over regulatory policy. The current Court's most prominent federalism cases-Lopez, Morrison, Printz, New York, and Seminole Tribe-all have involved fairly minor federal regulatory efforts with mostly symbolic impact. ${ }^{384}$

381. See, e.g., Duncan v. Louisiana, 391 U.S. 145, 173 (1968) (Harlan, J., dissenting) (protesting "the Court's continuing undiscriminating insistence upon fastening on the States federal notions of criminal justice"); Reynolds v. Sims, 377 U.S. 533, 624 (1963) (Harlan, J., dissenting) (complaining that the Court's recognition of "vote dilution" claims under the Equal Protection Clause effected "a radical alteration in the relationship between the States and the Federal Government"); Mapp v. Ohio, 367 U.S. 643, 680-81 (1961) (Harlan, J., dissenting) (arguing for state-by-state experimentation concerning remedies for Fourth Amendment violations).

382. Miranda, 384 U.S. at 467.

383. See, e.g., Romer v. Evans, 517 U.S. 620, 635-36 (1996) (holding that a Colorado constitutional amendment, which repealed ordinances prohibiting discrimination on the basis of sexual orientation, violated the federal Equal Protection Clause).

384. See, e.g., United States v. Morrison, 529 U.S. 598, 636 n.10 (2000) (Souter, J., dissenting) (noting, in connection with the federal Violence Against Women Act, that "I and other Members of this Court appearing before Congress have repeatedly argued against the federalization of traditional state crimes and the extension of federal remedies to problems for which the States have historically taken responsibility and may deal with today if they have the will to do so"); Printz v. United States, 521 U.S. 898, 902 (1997) (stating that the case involved the interim provisions of the Brady Act, designed to operate only until a wholly federal background 
The major impact of federalism doctrine on regulation occurs in the more obscure area of preemption. And in those cases, the most frequent pattern involves a regulated entity seeking to invalidate comparatively more rigorous state regulation based on an asserted conflict with more permissive federal rules. ${ }^{385}$

These efforts-despite the current Court's generally pro-state bent in the "big" cases-generally are successful. Consider, for example, the Court's recent decision in Lorillard Tobacco Co. v. Reilly. ${ }^{386}$ For over thirty years, the federal government has regulated tobacco advertising by requiring warning labels on cigarette packages and, more recently, by barring tobacco ads on television. Massachusetts, however, wished to go further in restricting the ability of tobacco companies to market their wares to children. ${ }^{387}$ The state attorney general accordingly promulgated a variety of additional restrictions on tobacco advertising, including a prohibition on tobacco advertising near schools where children would be particularly likely to see it. ${ }^{388}$

One might have thought, after Lopez, that state governmental authority reigns nowhere more supreme than within one thousand feet of a school. ${ }^{389}$ The Court nonetheless held all of the Massachusetts regulations preempted by the more permissive federal statute, despite a plausible argument by Justice Stevens in dissent that Congress's purpose in enacting the federal regulations was not to restrict

\footnotetext{
check system became operational); Seminole Tribe v. Florida, 517 U.S. 44, 74-76 (1996) (striking down the dispute resolution provisions of the Indian Gaming Regulatory Act); United States v. Lopez, 514 U.S. 549, 581 (1995) (Kennedy, J., concurring) (observing that "over 40 States already have criminal laws outlawing the possession of firearms on or near school grounds"); see also Lynn A. Baker, The Revival of States' Rights: A Progress Report and a Proposal, 22 HARV. J.L. \& PUB. POL'Y 95, 100 (1998) ("[N]either Lopez nor Printz has thus far proven to be a decision of wide-ranging import, although both have affected the legal landscape in discernible, if arguably marginal, ways.").

385. See, e.g., Lorillard Tobacco Co. v. Reilly, 121 S. Ct. 2404, 2410 (2001) (considering a tobacco company challenge to state regulation of tobacco advertising); Geier v. Am. Honda Motor Co., 529 U.S. 861, 864-65 (2000) (considering an automobile manufacturer's argument that state products liability claims were preempted by federal safety rules); United States v. Locke, 529 U.S. 89, 94 (2000) (considering the challenge by an association of oil tanker operators to state regulation of tanker safety and navigation); Medtronic, Inc. v. Lohr, 518 U.S. 470, 474 (1996) (considering the claim of a manufacturer of medical devices that state common law claims were preempted by federal regulation); Moran v. Rush Prudential HMO, Inc., 230 F.3d 959, 962 (7th Cir. 2000) (considering a health maintenance organization's challenge to a state regulation requiring independent physician review of decisions regarding patient treatment), cert. granted, 121 S. Ct. 2589 (2001).

386. 121 S. Ct. at 2410.

387. Id.

388. Id.

389. See id. at 2419 (Stevens, J., dissenting) (noting the ironic conjunction of Lopez and Lorillard).
} 
the location of advertising. ${ }^{390}$ The line-up of the Justices was striking: all five Justices who usually uphold state autonomy in cases under the Commerce Clause and the Eleventh Amendment were in the majority holding the state law preempted; all four more "nationalist" Justices were in dissent and would have protected Massachusetts from federal homogenization in this area. ${ }^{391}$ Even more striking for present purposes, though, is the extent to which national legislation has, through preemption of state laws, become an important force against economic regulation.

While current preemption doctrine does not share many doctrinal characteristics with Lochner, it is fair to say that it plays a similarly important role as a weapon against economic regulation. Stephen Gardbaum demonstrates that the primary thrust of the Lochner era was the Court's imposition of a uniform national economic policy of laissez-faire; although federalism doctrine was used as the weapon of choice against national legislation, the Court restricted state regulation with equal vigor under the Due Process Clause. ${ }^{392}$ Indeed, the elder Justice Harlan was not oblivious to the federalism implications of Lochner itself:

Let the State alone in the management of its purely domestic affairs, so long as it does not appear beyond all question that it has violated the Federal Constitution. This view necessarily results from the principle that the health and safety of the people of a State are primarily for the State to guard and protect. ${ }^{393}$

By overriding that principle, the Court's recent preemption cases make clear that nationalism can be a threat to progressive positions on economic regulation as well as an instrument for their vindication.

\footnotetext{
390. Id.

391. See Young, Two Cheers, supra note 93, at 1380-84 (noting a similar pattern in many of the Court's recent preemption cases).

392. See Stephen Gardbaum, New Deal Constitutionalism and the Unshackling of the States, 64 U. CHI. L. REV. 483, 566 (1997):

To a significant degree, the Lochner era federal courts took the lead in constraining state power in order to resist the reformist agendas of the Populist and Progressive movements, which had their greatest triumphs at the state legislative level and threatened to undermine what the courts viewed as the twin constitutional norms of freedom of contract and the national economy.

Professor Gardbaum goes on to argue that the New Deal Court's rejection of economic substantive due process "liberat[ed] the states to ... realize[] the vision expressed by Justice Brandeis [that] ' $[\mathrm{t}]$ here must be power in the States and the Nation to remould, through experimentation, our economic practices and institutions to meet changing social and economic needs." Id. (quoting New State Ice Co. v. Liebman, 285 U.S. 262, 311 (1932) (Brandeis, J., dissenting)).

393. Lochner v. New York, 198 U.S. 45, 73 (1905) (Harlan, J., dissenting).
} 
This use of federal authority-as a shield against economic regulation at the state level-ought to emphasize once again the inappropriateness of placing federalism on the "do not enforce" side of the double standard. To the extent that this standard evolved as a means of making the world safe for economic regulation while preserving "preferred" individual rights, it would be ironic if the unquestioned association of federalism with Lochner led to less experimentation with expanding individual rights and less economic regulation at the state level. To be sure, not all scenarios will play out this way. Sometimes states will be cautious about recognizing new rights, ${ }^{394}$ and sometimes restrictions on the scope of Congress's power will lead to less federal regulation rather than more. Our central point is simply that the relationships between federalism and rights, and between federalism and regulation, are complicated. Nothing as simplistic as the historical double standard is likely to capture that complexity in a meaningful or useful way.

\section{CONCLUSION}

Federalism has an image problem. In constitutional doctrine, it has been associated with freedom of contract and nondelegation and cast into exile for collaboration against the New Deal. In both popular and academic perception, it is so associated with slavery and segregation that the Founders' arguments for federalism as a bulwark of liberty no longer are taken seriously. ${ }^{395}$ And in modern political practice, federalism's success stories are ignored in favor of obsessive public fixation on the activities of the national government.

It may be that the federalist "turn" in the Supreme Court's jurisprudence also suffers from the fact that it is, in fact, a turn. Federalism

\footnotetext{
394. See, e.g., Romer v. Evans, 517 U.S. 620, 624 (1996) (invalidating a Colorado state constitutional amendment designed to preempt local ordinances prohibiting discrimination on the basis of sexual orientation).

395. Happily, even some "liberal" Justices have understood and have taken seriously the relationship between federalism and liberty. See, e.g., William J. Brennan, Jr., The Bill of Rights and the States: The Revival of State Constitutions as Guardians of Individual Rights, 61 N.Y.U. L. REV. 535, 535, 548-49 (1986) (noting with approval that state courts often have interpreted provisions in their constitutions to be more protective of individual rights than the analogous federal provisions, and celebrating the "double source of protection" for individual rights afforded by the federal system); William J. Brennan, Jr., State Constitutions and the Protection of Individual Rights, 90 HARV. L. REV. 489, 501 (1977) (observing that "[p]rior to the adoption of the federal Constitution, each of the rights eventually recognized in the federal Bill of Rights had previously been protected in one or more state constitutions"); see also, e.g., Coleman v. Thompson, 501 U.S. 722, 759 (1991) (Blackmun, J., dissenting) ("[F]ederalism secures to citizens the liberties that derive from the diffusion of sovereign power.") (emphasis added).
} 
has labored under the double standard for so long that any proponents of judicial review in federalism cases-no matter how mild that review ultimately might be in its application-are easily tarred as "extremists." As Robert Nagel eloquently argues, however, it is the "nationalists" who long have taken the more radical positions. ${ }^{396}$ Thus, the "most extreme version of radical nationalism proposes the elimination of the states, ${ }^{, 397}$ while "[m]odern antifederalists do not want to abolish the national government... . By and large, they do not even argue for significant changes in current political practices. The most that can be said is that they do not accept the view that states are of no value in our political system."

Professor Nagel concludes that "there is no antifederalist program equivalent to the radical nationalist position that dominates the case law and the academy and is taken for granted." ${ }^{399}$ An equivalently radical antifederalist proposal, he believes, "would be to abolish the national government and return to the kind of confederation that preceded unification. Such a return would involve abolishing the House of Representatives, the Presidency, much of the Judicial Branch, the Bill of Rights, national taxation, and all commerce clause regulation." ${ }^{400}$ Professor Nagel adds that "[a]s far as I know, no one on the Court or in the academy even mentions, much less supports, any of these changes." ${ }^{, 401}$

We have attempted, in this Article, to help "normalize" debates about federalism and judicial review. We have questioned the longstanding assumption that states' rights are somehow importantly different from other areas of constitutional law in which the necessity and value of judicial review are taken for granted. We have argued, therefore, that concerns about judicial competence, necessity, and the normative value of federalism are all insufficient to justify a double standard of judicial review between federalism and other constitu-

396. Robert F. Nagel, Real Revolution, 13 GA. ST. U. L. REV. 985 (1997).

397. Id. at 988 . Nagel notes that this "idea in one form or another has had advocates as far back as Alexander Hamilton, and an adventuresome modern thinker occasionally mentions some variation. Such proposals are important mainly in indicating how wide the range of permissible discourse is among radical nationalists." Id. (footnotes omitted).

398. Id. at 1003 .

399. Id. at 996.

400. Id.

401. Id. Mr. Young wishes to note that while his coauthor has proposed a radical restructuring of one whole chamber of the national legislature, see Lynn A. Baker \& Samuel H. Dinkin, The Senate: An Institution Whose Time Has Gone?, 13 J.L. \& PoL. 21, 23 (1997), the most radical thing he has ever proposed is the application of the Erie doctrine in maritime cases. Ernest A. Young, Preemption at Sea, 67 GEO. WASH. L. REV. 273, 277 (1999). 
tional principles. To say that, of course, is merely to begin a long and complex discussion about what sort of judicial review we should have in this area. That conversation cannot move forward, however, until we welcome constitutional federalism home from its long "exile." 